


\section{Predicting Plant Communities in the vicinity of agricultural fields/vineyards in Europe to inform non-target terrestrial plant risk assessment}

Arts, G.H.P., S.M. Hennekens, P.J.F.M. Verweij, M. van Eupen

This research was funded by CropLife Europe and was supervised by its Non-Target Plant Group: Rena Isemer (Chair; Bayer AG), Joanna Davies (Syngenta), Eileen Patterson (Corteva), Stefania Loutseti (Syngenta), Christoph Julian Mayer (BASF)

Wageningen Environmental Research

Wageningen, June 2021

The QUICKScan tool and databases can be downloaded from (http://www.QUICKScan.pro).

Reviewed by:

Anouk Cormont, researcher (Wageningen Environmental Research)

Approved for publication:

Dr. Bram de Vos, Managing Director (Environmental Sciences Group)

Report 3096

ISSN 1566-7197 
Arts, G.H.P., S.M. Hennekens, P.J.F.M. Verweij, M. van Eupen, 2021. Predicting Plant Communities in the vicinity of agricultural fields/vineyards in Europe to inform non-target terrestrial plant risk assessment. Wageningen, Wageningen Environmental Research, Report 3096. 110 pp.; 10 fig.; 1 tab.; 18 ref.

The terrestrial plant risk assessment of pesticides is currently based on testing 10 single species in two different test systems. These species are mostly crop species, grown as single species in pots. Higher tier tests of any kind (e.g. field, semi-field, landscape studies) are not standardized. In this study we explored an approach to inform such a higher level by collecting datasets and information at European scale to characterize the vegetation communities that are likely to grow in the off-field areas of wheat and vine crops. This study was performed at the request of CropLife Europe and its Non-Target Plant group. The QUICKScan methodology (http://www.QUICKScan.pro) was used to combine all data. Habitat suitability maps were generated and combined with crop distribution maps for wheat and vine to generate potential occurrence maps of EUNIS habitats and their vegetation in agricultural land surrounding wheat and vine crops and were linked with plant trait information. We conclude that this method is helpful in reaching the objective as described in this report. Its potential is that it can be extended probabilistically or linked to plant effect models.

Keywords: terrestrial plants, risk assessment, agricultural landscape, QUICKScan tool, off-field, plant communities, Europe

The pdf file is free of charge and can be downloaded at https://doi.org/10.18174/549894 or via the website www.wur.nl/environmental-research (scroll down to Publications - Wageningen Environmental Research reports). Wageningen Environmental Research does not deliver printed versions of the Wageningen Environmental Research reports.

2021 Wageningen Environmental Research (an institute under the auspices of the Stichting Wageningen Research), P.O. Box 47, 6700 AA Wageningen, The Netherlands, $\mathrm{T}+31$ (0)317 4807 00, www.wur.nl/environmental-research. Wageningen Environmental Research is part of Wageningen University \& Research.

- Acquisition, duplication and transmission of this publication is permitted with clear acknowledgement of the source.

- Acquisition, duplication and transmission is not permitted for commercial purposes and/or monetary gain.

- Acquisition, duplication and transmission is not permitted of any parts of this publication for which the copyrights clearly rest with other parties and/or are reserved.

Wageningen Environmental Research assumes no liability for any losses resulting from the use of the research results or recommendations in this report.

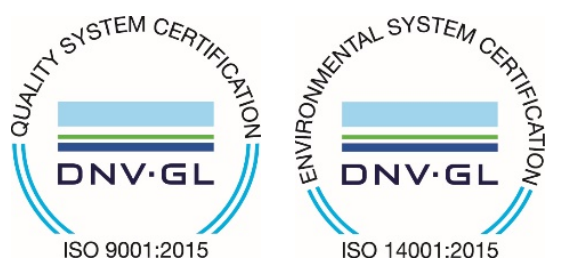

In 2003 Wageningen Environmental Research implemented the ISO 9001 certified quality management system.

Since 2006 Wageningen Environmental Research has been working with the ISO 14001 certified environmental care system.

By implementing the ISO 26000 guideline, Wageningen Environmental Research can manage and deliver its social responsibility.

Wageningen Environmental Research report 3096 | ISSN 1566-7197

Photo cover: Non-target terrestrial field off-field area alongside a grain crop 


\section{Contents}

$\begin{array}{lr}\text { Verification } & 5\end{array}$

$\begin{array}{ll}\text { Preface } & 7\end{array}$

Summary 9

1

$\begin{array}{lr}\text { Introduction } & 11\end{array}$

1.1 Vision on the assignment 11

$\begin{array}{lll}1.2 & \text { Characterization of vegetation in off-field areas } & 12\end{array}$

$\begin{array}{lll}1.3 \text { Aim } & 12\end{array}$

$\begin{array}{lll}1.4 & \text { Research questions } & 12\end{array}$

$2 \quad$ Materials and methods $\quad 13$

2.1 Data 13

2.1.1 Overview of collected data 13

2.1.2 Habitat classification 13

2.1.3 European Vegetation Archive 14

2.1.4 Habitat suitability maps $\quad 15$

2.1.5 Crop distribution maps $\quad 15$

2.1.6 Trait databases 15

2.2 QUICKScan tool 17

$\begin{array}{lll}2.3 \text { Method } & 17\end{array}$

$3 \quad$ Results $\quad 18$

3.1 Species and families in the off-field area $\quad 18$

3.2 Habitat suitability maps and potential occurrence of EUNIS habitats 18

$\begin{array}{lll}3.3 & \text { Plant traits } & 20\end{array}$

3.4 Summary of traits for use in QUICKScan $\quad 26$

$\begin{array}{lll}3.5 & \text { Trait maps } & 26\end{array}$

$4 \quad$ Conclusions and discussion $\quad 27$

$\begin{array}{lll}4.1 & \text { Characterizing the off-field area } & 27\end{array}$

4.2 Workshop with CropLife Europe $\quad 28$

$\begin{array}{ll}\text { References } & \mathbf{3 0}\end{array}$

Annex 1 Predictors for habitat suitability modelling 32

Annex 2 References of original individual datasets in TRY 34

Annex $3 \quad$ Plant families per EUNIS habitat 36

Annex 4 List of 329 plant species of the eight EUNIS habitats 40

Annex 5 Species list per EUNIS habitat 446

Annex 6 Summary of traits (binary categories) for use in QUICKScan. 59

Annex $7 \quad 47$ maps including suitability maps for the eight EUNIS habitats, the potential occurrence maps of the eight EUNIS habitats in agricultural land surrounding wheat crops and surrounding vineyards and trait maps for the example trait annual vs non-annual 



\section{Verification}

Report: 3096

Project number: 5200045101

Wageningen Environmental Research (WENR) values the quality of our end products greatly. A review of the reports on scientific quality by a reviewer is a standard part of our quality policy.

Approved reviewer who stated the appraisal,

position: Researcher Wageningen Environmental Research

name: $\quad$ Anouk Cormont

date: $\quad 4$ June 2021

Approved team leader responsible for the contents,

name: Dr. Bram de Vos, Managing Director (Environmental Sciences Group)

date: 21 June 2021 


\section{Preface}

This study was performed for CropLife Europe in the period 2019 - 2021.

This study was supervised by its Non-Target Plant Group: Rena Isemer (Chair), Joanna Davies, Eileen Patterson, Stefania Loutseti, Christoph Julian Mayer, Tiffany Kung. 


\section{Summary}

The terrestrial plant risk assessment of pesticides is currently based on testing 10 single species in two different test systems. These species are mostly crop species, grown as single species in pots. Higher tier tests of any kind (e.g. field, semi-field, landscape studies) are not standardized. In this study we explored an approach to inform such a higher level by collecting datasets and information at European scale to characterize the vegetation communities that are likely to grow in the off-field areas of wheat and vine crops. This study was performed at the request of CropLife Europe and its Non-Target Plant group. In the long run, the method should help to describe 5-10 surrogate plant communities that could serve as a reference tier in terms of habitats, functionalities and structures at European level to be used in the risk assessment and/or to inform higher-tier testing for herbicides. As a first step, the year 2019 was dedicated to exploring data that could be used to identify plant communities and plant species and their predictors at the landscape level that are characteristic for the vicinity of agricultural areas in Europe. In 2020/21, further work was performed on linking the available databases, data-sets and expert information by means of the QUICKScan tool (http://www.QUICKScan.pro). This is a spatial modelling environment that combines expert knowledge with spatial and statistical data. The EUNIS (European Nature Information System; https://eunis.eea.europa.eu/) habitat classification has been used as a basis to identify the eight man-made habitats characteristic of agricultural cropped areas. These habitats are spatially identified on the bases of a modelling process where vegetation plots, taken from the European Vegetation Archive (http://euroveg.org/eva-database), were used as observations and climate, soil, topographic, population density parameters and Remote Sensed Essential Biodiversity Variables as predictors. This modelling resulted in habitat suitability maps. The habitats include 329 species, belong to 45 plant families and refer to 46579 vegetation plot observations in the European Vegetation Archive. The habitat suitability maps were combined with crop distribution maps for wheat and vine to generate potential occurrence maps of EUNIS habitats in agricultural land surrounding wheat and vine crops. Plant traits including leaf type, monocotyledon / dicotyledon category, plant functional type, plant life span (longevity) and seed longevity were requested from the TRY plant trait database (https://www.try-db.org/TryWeb/Home.php), extended with the Raunkiaer life forms and used to collate a characteristic trait spectrum and distribution map per EUNIS habitat. The QUICKScan methodology (https://www.QUICKScan.pro/) was used to combine all these data. We conclude that this method is helpful in reaching the objective as described in this report. Its potential is that it can be extended probabilistically or linked to plant effect models.

Keywords: terrestrial plants, risk assessment, agricultural area, QUICKScan tool, off-field, plant communities, Europe 


\section{Introduction}

The terrestrial plant risk assessment of pesticides is currently based on testing 10 single species in two different test systems. These species are mostly crop species, grown as single species in pots. Higher tier tests of any kind (e.g. field, semi-field, landscape) are not standardized. From the field up to the landscape level, the question arises how such a higher tier assessment could be performed for terrestrial plants. At these higher levels, the biological organization is not the species, but rather the plant community. Therefore, at the request of CropLife Europe (CLE), Non-Target Plant group, a project was initiated to develop a method for the deduction of representative plant communities in the off-field area. As a first step, the year 2019 was dedicated to exploring data that could be used to identify plant communities and plant species and their predictors at the landscape level that are characteristic for the vicinity of agricultural areas in Europe. Subsequently, the QUICKScan method was used to combine all data with focus on plant communities surrounding two crops, i.e. wheat and vine crops. Potentially, the approach could also be used for other crops where data is available. This report explains the datasets at European level used for this study, the background of the QUICKScan methodology and presents the results.

In the long run, the methodology should help to describe 5-10 surrogate plant communities e.g. to inform on reference tier(s) to be used in the risk assessment and/or to inform on non-target plant testing approaches for herbicides and other plant protection products. The specific objectives of this project are in short:

1. Characterization of wild plant communities in the vicinity of agricultural fields (off-field) in Europe;

2. Defining the spatial scale of these communities;

3. Translating these plant communities in terms of habitats and functionalities;

4. Defining the time scale and succession of these plant communities;

5. Describing management of field margins and similar structures in European agricultural landscapes.

It is specifically the aim of the project to look at wild plant communities that are located in the agricultural landscape (just) outside of agricultural fields, the so-called off-field plant communities. Infield plant communities are outside the scope of this project. The project has been divided into different phases. In the year 2018, the proposal has been prepared and granted. Based on this project proposal, a projectplan was developed in more detail in cooperation with a project monitoring group consisting of members of the CLE Non-Target Plant Group. During the first year of the project, which was 2019, the project was dedicated to data selection, data evaluation and exploration of the available literature. The year 2020 was dedicated to data analysis and further development of the QUICKScan methodology. As a case study, wheat crops were elaborated. In 2021 a second crop was added as a case study, i.e. vine. The results of the overall project are published in this report and in a paper.

\subsection{Vision on the assignment}

We explored a number of databases ready for use in a data analysis to answer the central objectives of the project as described above.

The focus laid on off-crop plant communities and included information on selected crops at European scale. The reason is that there is a relation between plants growing in-field and growing in the off-field area which means that the crop grown on the field should be considered when performing an nontarget plant-based risk assessment addressing the plant communities off-field. Factors responsible for this are, among others, soil type, crop type and land management. 


\subsection{Characterization of vegetation in off-field areas}

The 10 anthropogenic vegetation classes as described by Mucina (2016) are part of a scientific vegetation classification (https://www.synbiosys.alterra.nl/evc). This vegetation classification is a hierarchical classification system and is based on a characterization of different plant species groups, i.e. characteristic, discriminating and constant plant species. The EUNIS system is very different from this hierarchical vegetation classification and is a habitat classification that is more practical by nature. As the elaboration of the EUNIS habitat classification for man-made habitats had been finished early 2020 (Schaminée et al., 2020), we could make use of these elaborated data to characterize the offfield habitats of agricultural fields by their vegetation, their plant communities, families and species.

\subsection{Aim}

At the request of CropLife Europe (CLE), the ultimate aim of this project is to deduce an appropriate number (presumably 5 - 10) of representative plant communities in terms of habitats, functionalities and structures at European level in off-field areas to inform risk assessment for herbicides. The databases include realistic data collected in field studies and vegetation assessments so they are considered quite reliable. Validation of the tool and results would be useful but is not part of this project.

In order to achieve this goal, we applied the QUICKScan spatial modelling environment in which we have included predictors for the occurrence of vegetation (classes, communities and / or habitats characterized by indicator species) and their traits in agricultural off-field areas in Europe.

\subsection{Research questions}

Based on the general aim of the project, the research questions are:

- Which typical vegetation is likely to grow in the off-field area given biophysical (climate, soil, hydrology, elevation, aspect, slope), plant-sociological and potentially landscape characteristics?

- How can this vegetation be characterized by their plant traits?

In order to answer these questions we applied the QUICKScan spatial modelling tool. 


\section{$2 \quad$ Materials and methods}

\section{$2.1 \quad$ Data}

\subsubsection{Overview of collected data}

For the data analysis we collated the following datasets and maps:

- Man-made habitats characteristic for the off-field area in agricultural landscapes (par. 2.1.2);

- Plant species information for each of these habitats (par. 2.1.3);

- Habitat suitability maps for the eight EUNIS man-made habitats characteristic in off-field areas (par. 2.1.4);

- Crop distribution maps for wheat and vine (par. 2.1.5);

- Trait databases (par. 2.1.6)

The QUICKScan methodology (https://www.QUICKScan.pro/) was used to combine all these data.

\subsubsection{Habitat classification}

The EUNIS (European Nature Information System) habitat classification is a reference framework for European habitats (https://eunis.eea.europa.eu/habitats-code-browser.jsp?expand=58\#level_58). It intends to classify all habitats in Europe. Recently, the man-made habitats (type I: regularly or recently cultivated agricultural, horticultural and domestic habitats) were revised and published (Schaminée et al., 2020). For the current project, the vegetation communities of these man-made habitats have been expressed in terms of species and distribution maps. Each EUNIS habitat is characterized by all the species occurring in this specific EUNIS type with a frequency $>5 \%$. Six of these man-made EUNIS habitats were initially identified as relevant for agricultural cropped areas (V-habitats V11- V13 en V37 - V39). In order to cover the areas where vine crops are cultivated in Europe, the EUNIS habitats V34 and V35 were added.

These eight habitats are:

V11 Intensive unmixed crops (Cereal and other non-woody crops grown on large, unbroken surfaces in open field landscapes)

V12 Mixed crops of market gardens and horticulture: Intensive cultivation of vegetables, flowers, small fruits, usually in alternating strips of different crops. Includes allotments and small-scale market gardens

V13 Arable land with unmixed crops grown by low-intensity agricultural methods

V34 Trampled xeric grassland with annuals

V35 Trampled mesophilous grassland with annuals

V37 Annual anthropogenic herbaceous vegetation: Stands dominated by annual herbaceous plants developing on recently abandoned urban or agricultural land

V38 Dry perennial anthropogenic herbaceous vegetation: Stands dominated by perennial herbaceous plants, frequently ruderals, developing on dry abandoned urban or agricultural land

V39 Mesic perennial anthropogenic herbaceous vegetation: Stands dominated by perennial herbaceous plants, frequently ruderals, developing on mesic to slightly wet abandoned urban or agricultural land

These EUNIS habitats mostly include nutrient-rich vegetation types, only V13 represents a vegetation type with a lower nutrient status. V34 and V35 are representative of dry and warm (trampled) habitats. The EUNIS habitats were screened for in-field releves as this project is focusing on the offfield area. The in-field releves could be recognized by a high dominance of crop species (wheat in the case of the wheat crop). These releves were deleted from the selection. The in-field releves were only relevant for EUNIS types $\mathrm{V} 11, \mathrm{~V} 12$ and $\mathrm{V} 13$. 


\subsubsection{European Vegetation Archive}

The primary data source for producing lists of species and maps for the EUNIS habitats were European vegetation plot records. Such plots typically contain a full list of vascular (and often also non-vascular) plant species, estimation of cover-abundance of each species, location and various additional information on vegetation structure and environmental features in the plot (Schaminée et al. 2009). These plots were compiled from the European Vegetation Archive (Chytrý et al. 2016; 2020). On 28 November 2019, the EVA dataset contained a total of 1,847,463 vegetation plots from Europe, of which 1,612,287 were georeferenced (see Figure 1). 46579 plots (Chytrý et al., 2020) were assigned to the eight man-made habitats mentioned in the previous paragraph. Most data used in this exercise were from this century (since the year 2000).

The assignment of vegetation plots to EUNIS habitats was performed through expert rules (Chytrý et al., 2020): formal query routines in which formal definitions of habitats are based on plant species composition, the dominance of specific plant species, and also geographical criteria (Schaminée et al. 2016, 2018; Chytrý et al., 2020). Each habitat was formally defined as a formula in a computer language combining algebraic and set-theoretic concepts with formal logical operators (Chytrý et al., 2020). This expert system was used to classify vegetation plots from the Vegetation Archive (EVA) and other databases. Then species for each habitat were identified by calculating species-to-habitat occurrence frequency in the data set. Finally, the plot locations were mapped for each habitat. Using this approach, all eight man-made habitats were defined with regard to the species and their frequencies found in each habitat. For a more detailed background to this methodology see Chytrý et al. (2020).
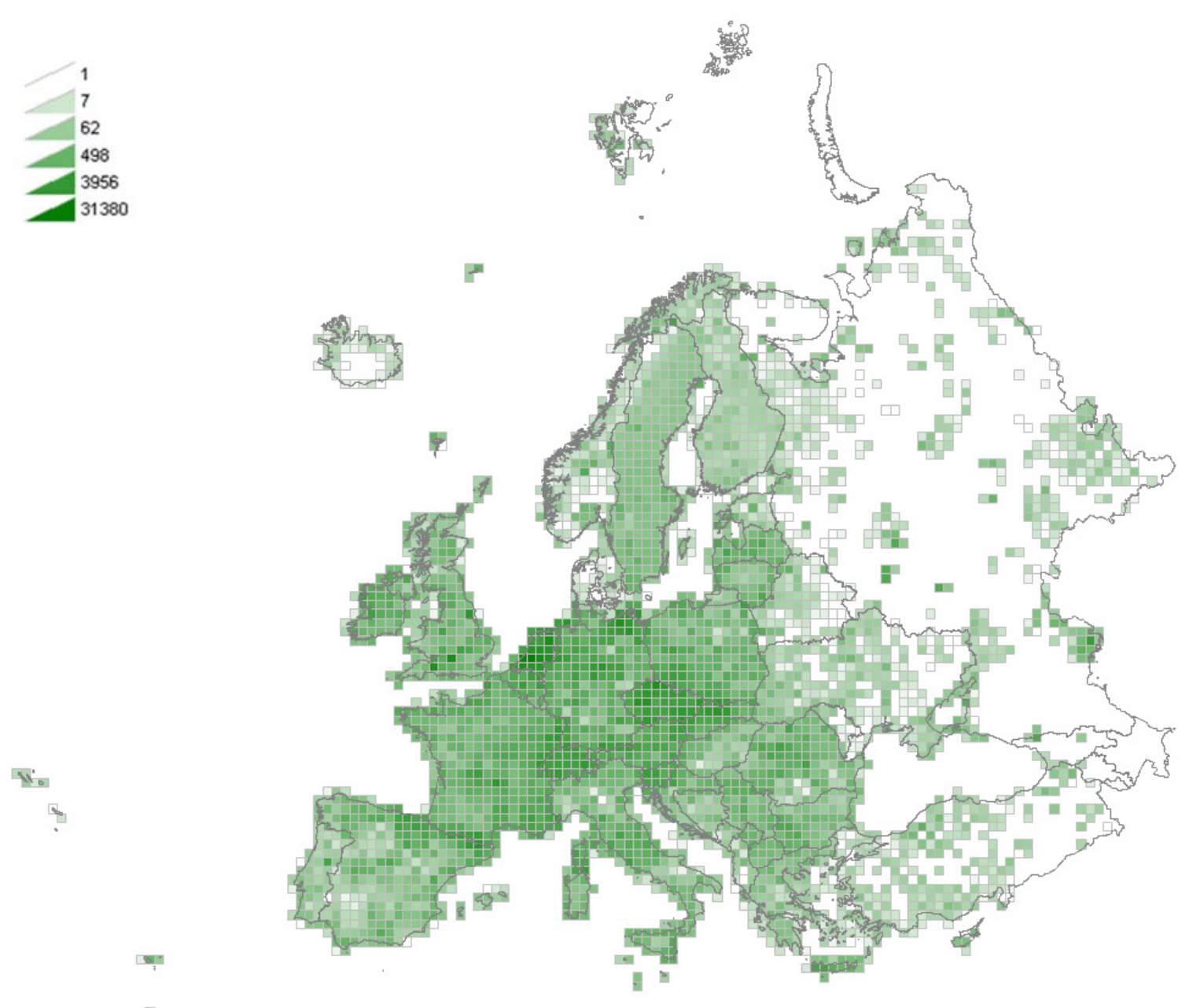

Figure 1 Density distribution of the total of 1,612.287 georeferenced plots in EVA and other plots provided for this project in $50 \times 50 \mathrm{~km}$ grid cells (accessed on 28 November 2019). 


\subsubsection{Habitat suitability maps}

Where a vegetation class or reference community or habitat potentially may occur, can be predicted (modelled) by drivers like climate, soil, topography and remote sensed Essential Biodiversity Variables (RS-EBV's). For the complete list of predictors used check the Annex 1. The result of such prediction is a series of suitability maps (Hennekens, 2020). These maps have currently a resolution of $1 \times 1 \mathrm{~km}$.

For habitat suitability modelling, the latest version of the widely used software Maxent 1 for maximum entropy modelling of species geographic distributions was used. Maxent is a general-purpose machinelearning method with a simple and precise mathematical formulation, and has a number of aspects that make it well-suited for species distribution modelling when only presence (occurrence) data but not absence data are available (Philips et al. 2006). Because EUNIS habitats have a particular species composition, they are assumed to respond to specific ecological requirements, allowing us to generate correlative estimates of geographic distributions. Modelling habitats that have been floristically defined is a well-known procedure for ecological modelling at local scales, and a promising technique to be applied also at the continental level.

The habitat suitability maps were loaded in the QUICKScan tool and further analysed using the other databases as described in par. 2.1.1.

\subsubsection{Crop distribution maps}

Crop distribution maps for wheat and vine were based on the Eurostat data from 2010 with a solution of $1 \times 1 \mathrm{~km}$. MAPSPAM was suggested as an alternative. MAPSPAM data is based on more than one year and also includes area, yield and crop intensity. For the final analysis Eurostat was used.

\subsubsection{Trait databases}

The TRY database (Kattge et al., 2020) was used to extract information about plant traits considered relevant to inform the risk assessment for terrestrial plants in the vicinity of agricultural cropped areas. Traits were selected for which information was available for a large number of plants in the TRY database. These traits included leaf type, monocotyledon / dicotyledon category, plant functional type, plant life span (longevity) and seed longevity. An official request for the use of these data was submitted to the TRY database holders and was approved. Subsequently the trait categories were synchronized as diverse categories of original data were used to allocate the data in the TRY database (see Annex 2 for the original references of individual datasets).

\footnotetext{
1 Maxent version 3.4.1 was used. http://biodiversityinformatics.amnh.org/open_source/maxent/
} 


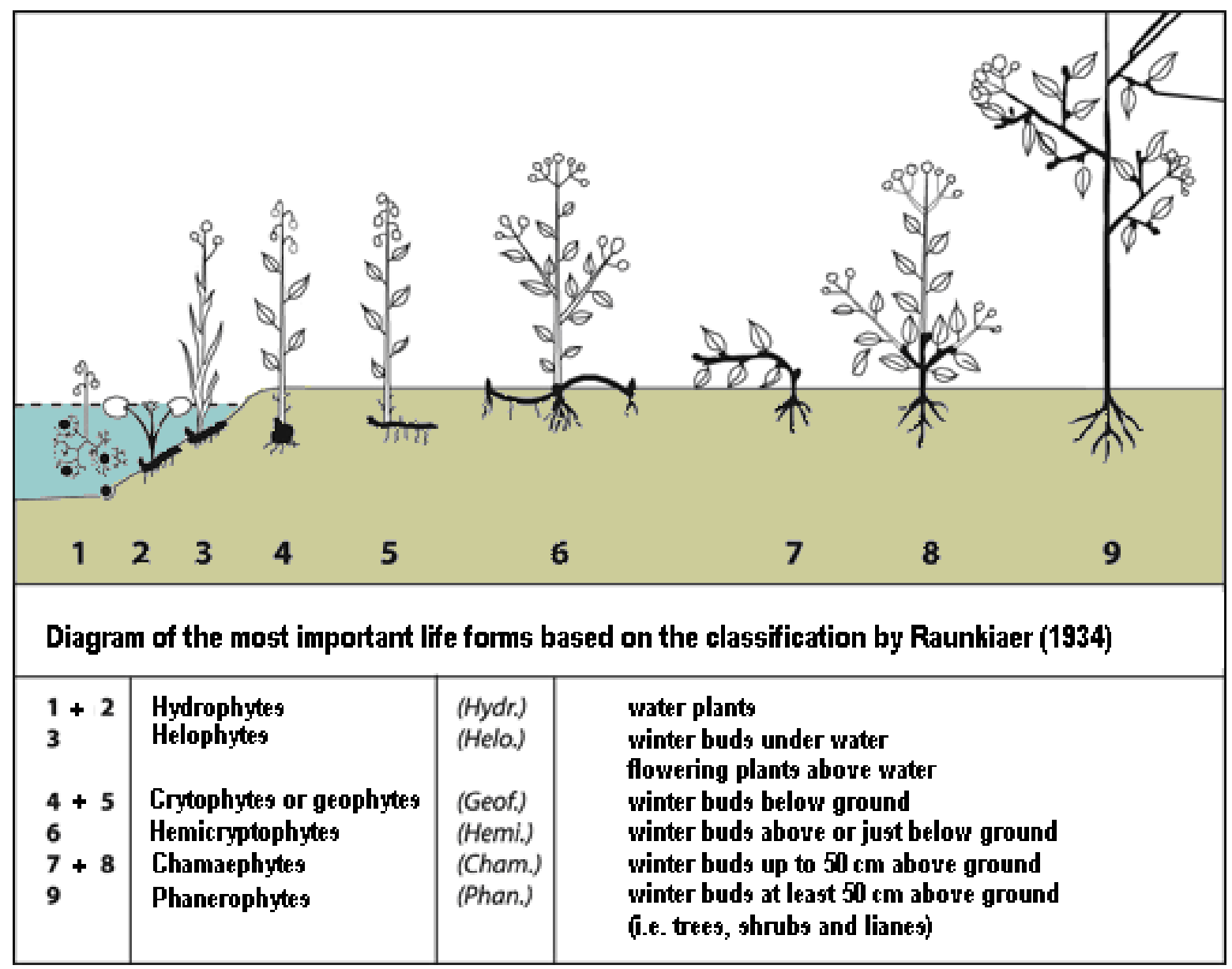

Figure 2 Raunkiaer life forms (Therophytes are missing; https://www.vcbio.science.ru.nl/en/ virtuallessons/landscape/raunkiaer/)

The quantitative data for the species in the EUNIS habitats (species counts) were transformed into total scores. These scores per trait (cumulative frequency values) and per EUNIS habitat have been used to collate a characteristic trait spectrum per EUNIS habitat in the form of tables and pie charts.

The plants traits were extended with the Raunkiaer life forms (Fig. 2) (unpublished data I. Axmanová). Raunkiær (1934) has classified plants according to the place where the growth point is located during the unfavourable season, provided the plant maintains the capability to survive these difficult conditions. Such an unfavourable period might be the cold winter period or the dry summer time.

The life form categories of Raunkiaer include: Phanerophyte, Tree, Shrub, Chamaephyte, Semi-shrub, Dwarf shrub, Hemicryptophyte, Geophyte, Hydrophyte, Therophyte, Epiphyte, Woody Liana. Not all these categories are relevant for the plants growing off-field. The species list in the off-field area was matched with the dataset including the Raunkiaer life forms generating the life forms of the species in the off-field area.

In order to map traits in the QUICKScan tool, the trait categories were simplified and re-ordered into two categories. E.g. the trait plant life span (longevity) includes 5 categories (annual, annual-biennial, biennial, biennial-perennial and perennial. For use in QUICKScan, these trait categories were summarized into two categories: annual and non-annual. Other traits were simplified in a similar way. Only the Raunkiaer growth form was summarized into three categories. For the purpose of a quantitative comparison of the trait spectra among the EUNIS habitats, the traits were scaled towards the maximum trait value and towards the maximum trait category value. 


\subsection{QUICKScan tool}

The QUICKScan tool (https://www.QUICKScan.pro/) was used to link all databases (Verweij et al., 2016). It is a spatial modelling environment that combines expert knowledge with spatial and statistical data. QUICKScan is a participatory modelling method that links stakeholder- and decision maker knowledge and preferences to available spatial and spatio-statistical data. An iterative approach can be followed, starting with simple (knowledge-based) rules and step-by-step adding complexity, using interpretation of model-results. Successive iterations can be used to 1 ) improve the quality of the model, 2) try out alternative (spatial)plans and policy options and 3) include different stakeholder values and perspectives.

Results are visualized in interactive maps, summary charts and trade-off diagrams. There is a variety of linkable rule types ranging from qualitative knowledge matrices and Bayesian Belief Networks to include uncertainties, to multicriteria, indicator standardization and sustainability limit tools.

QUICKScan can show how a result is reached by visualising the chain of knowledge and the data, for any specific location in a study area.

The tool can be applied probabilistically or mechanistically. Both aproaches were explored in this project.

\subsection{Method}

In order to follow the QUICKScan methodology, we organized several brainstorm sessions, collated data at European level, interactively linked datasets, collected new datasets etc. in an iterative process.

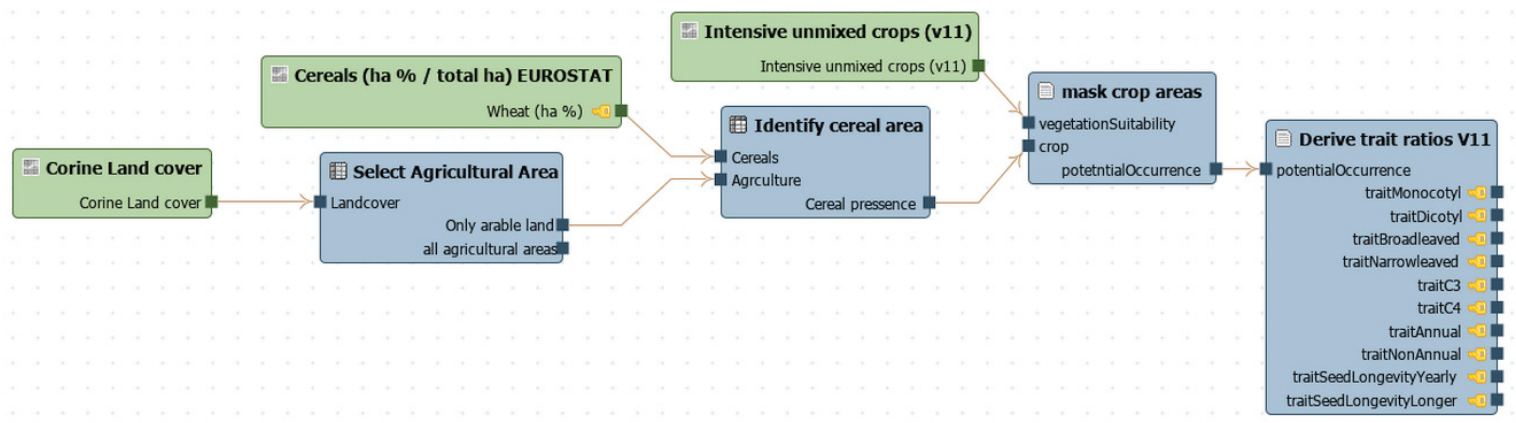

Figure 3 Flow diagram in QUICKScan.

Overlays were constructed of the suitability maps for the eight EUNIS habitats with the crop distribution maps for wheat and vine crops. The results are potential occurrence maps for each EUNIS habitat in agricultural wheat and vine off-field areas. The species list in the off-field area was matched with the trait dataset generating the traits of these species. For the purpose of a quantitative comparison of the trait spectra among the EUNIS habitats, the traits were scaled towards the maximum trait value and towards the maximum trait category value. Figure 3 presents the flow diagram in QUICKScan. The same approach was followed for vine. 


\section{Results}

\subsection{Species and families in the off-field area}

The eight EUNIS habitats include 329 species with a frequency larger than 5\% (that means occurring in more than $5 \%$ of the releves), belonging to 45 plant families. Annex 3 includes a list of plant families represented in the eight EUNIS habitats. Annex 4 includes the full list of plant species of the eight EUNIS habitats. Annex 5 includes the species list per EUNIS habitat.

Figure 4 presents the diversity in potential plant families in EUNIS habitats.

\section{$\mathrm{N}$ families per EUNIS habitat and used in 1st tier tests}

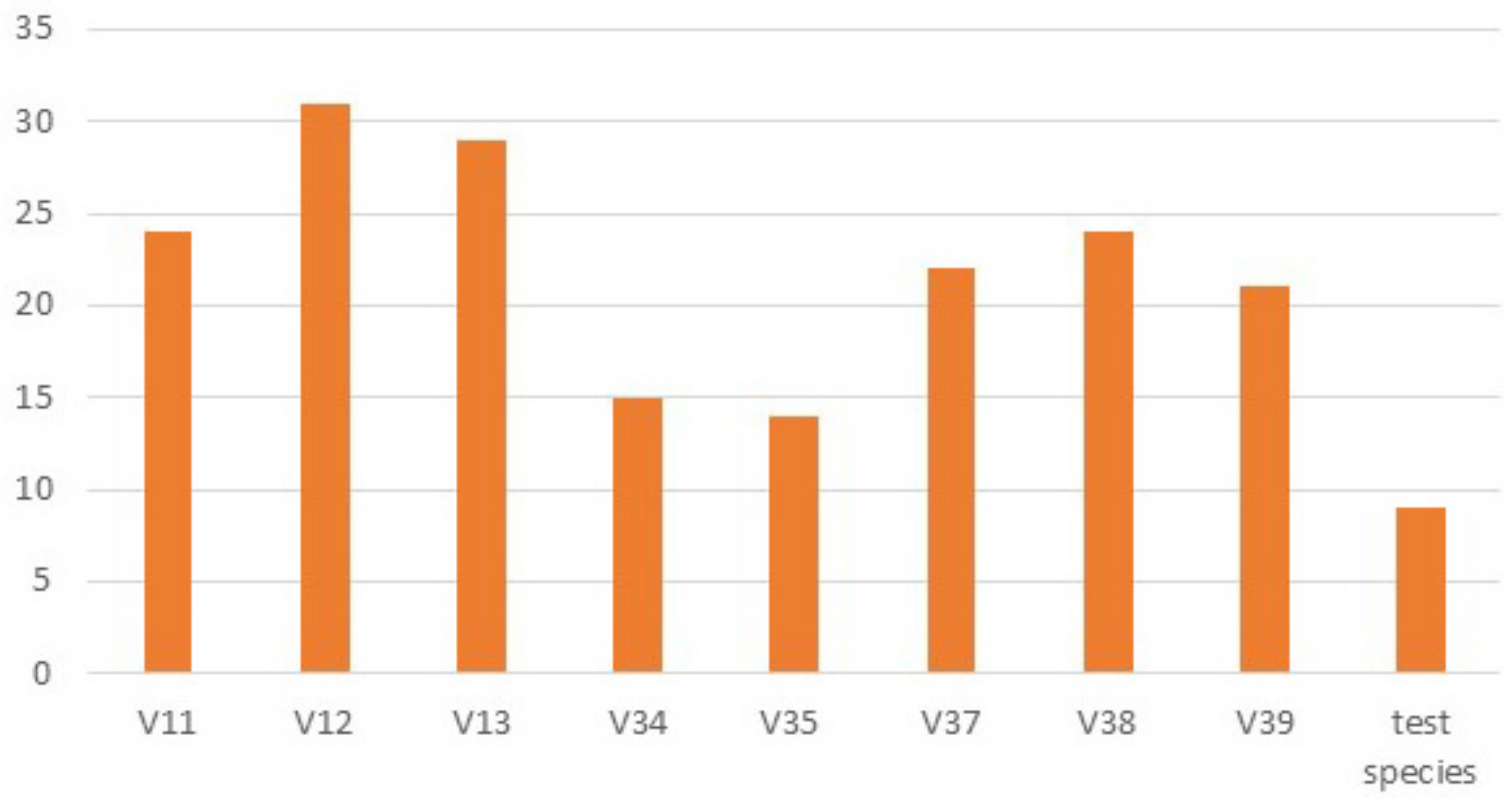

Figure $4 \quad$ Number of plant families in EUNIS habitats in agricultural areas compared to the number of families to which the standard non-target plant test species belong.

\subsection{Habitat suitability maps and potential occurrence of EUNIS habitats}

The EUNIS V-habitat suitability maps combined with wheat crop distribution maps and vine distribution maps and with plant traits. Figure 5 and 6 present examples of such maps for habitat V11. All maps are included in the attached file 'Habitat suitability and potential occurrence maps' (Annex 7). 


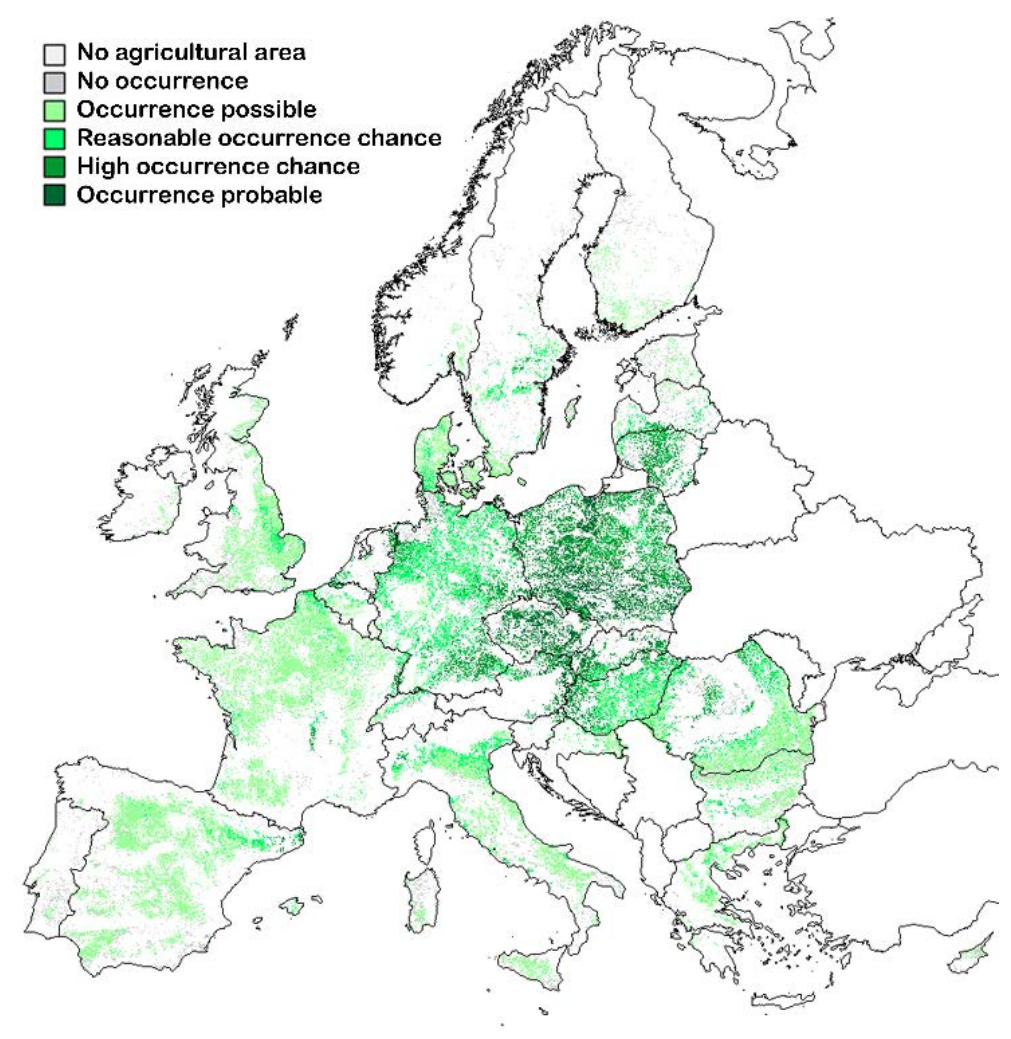

Figure 5 Potential occurrence of one of the EUNIS habitats (V11) in agricultural land surrounding wheat crops. The higher the potential occurrence, the more intense the green color.

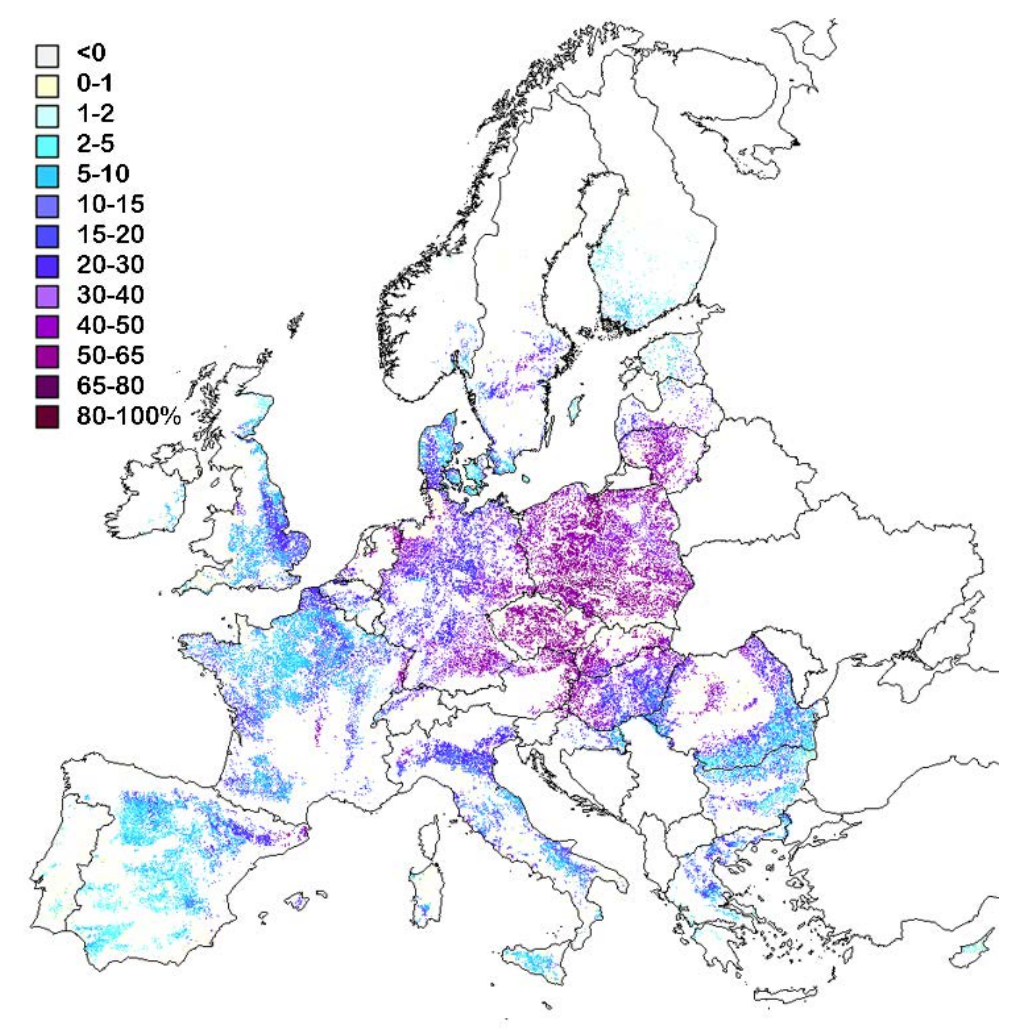

Figure 6 Potential occurrence of the 'annual species' trait in agricultural land surrounding wheat crops. The higher the trait percentage in this habitat, the more intense the purple color. 


\subsection{Plant traits}

The results of the plant traits leaf type, monocotyledon / dicotyledon category, plant functional type, plant life span (longevity), seed longevity and Raunkiaer life forms are presented in the next figures in this paragraph. The trait spectra are presented per EUNIS habitat as pie diagrams. The EUNIS habitats are characterized by a long list of plant species (Annex 6) with their trait categories. The distribution of the traits over the habitats is presented in pie diagrams as shown in the next figures in this paragraph.
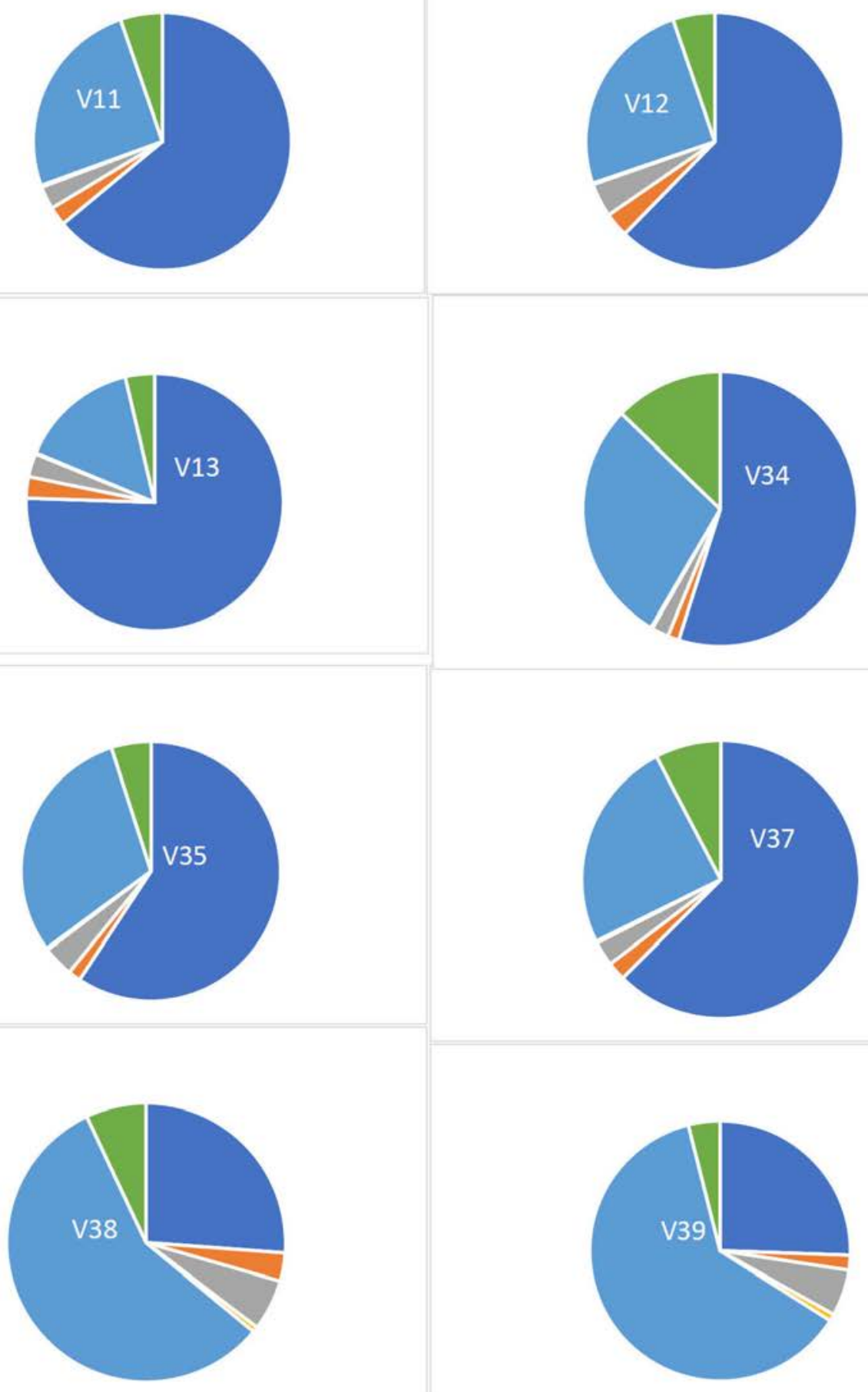


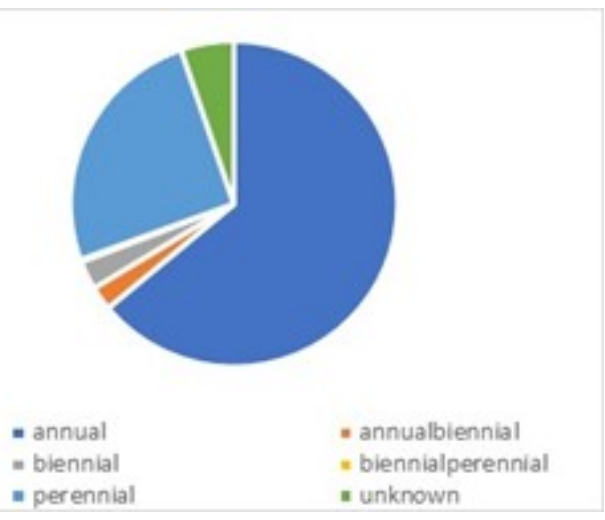

Figure $7 \quad$ Spectra of the trait 'plant lifespan (longevity)' for the eight EUNIS habitats. Each panel of Figure 7 represents a different EUNIS habitat.

Figure 7 shows that all EUNIS habitats except for habitats V38 and V39 are dominated by annual plants (the dark blue color in the pie diagrams). Annual species are plant species that perform their full life cycle, from germination until production of seeds, within one year. On the contrary, the EUNIS habitats V38 and V39 are dominated by perennial plant species. These plant species live longer than two years.

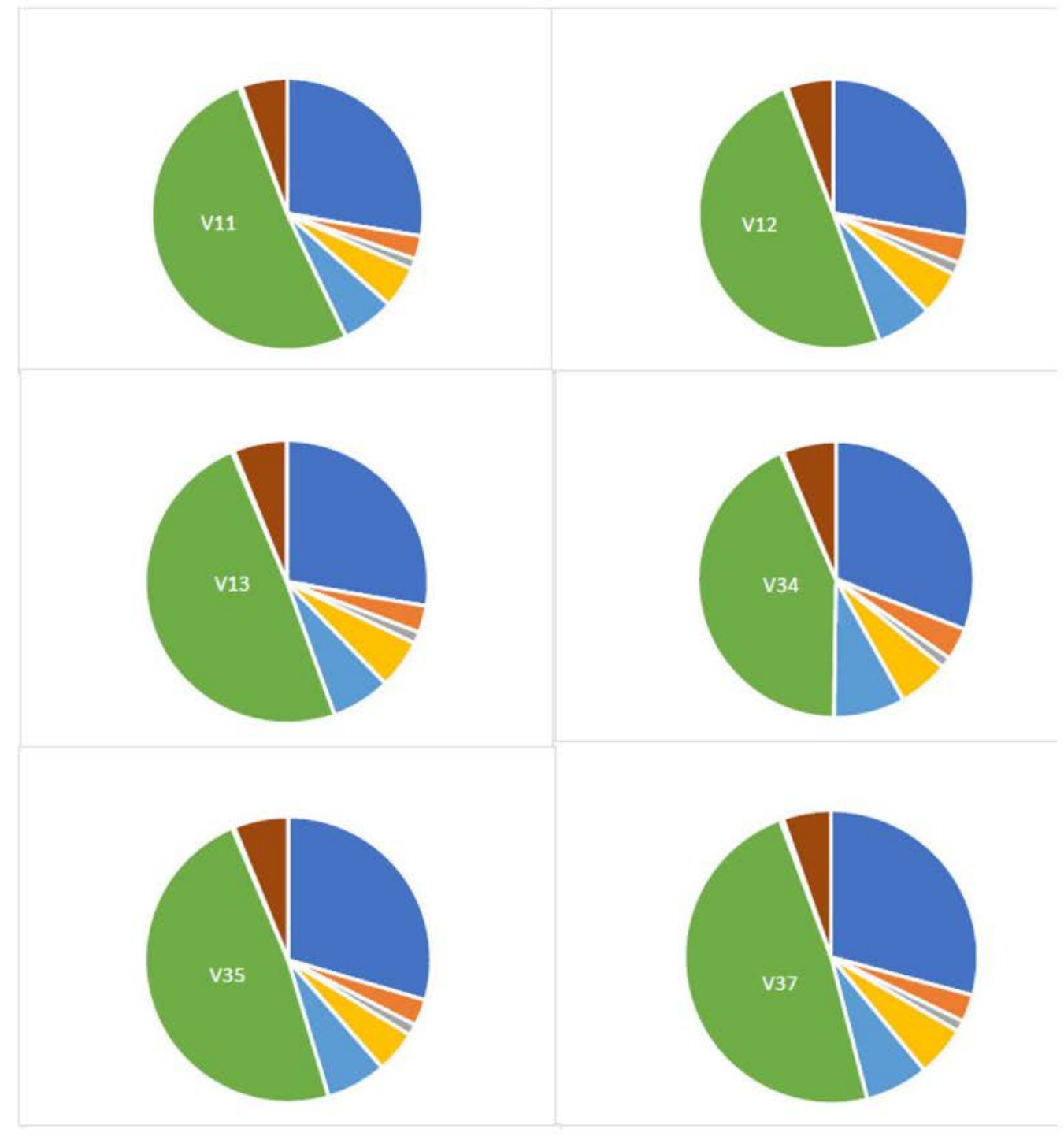




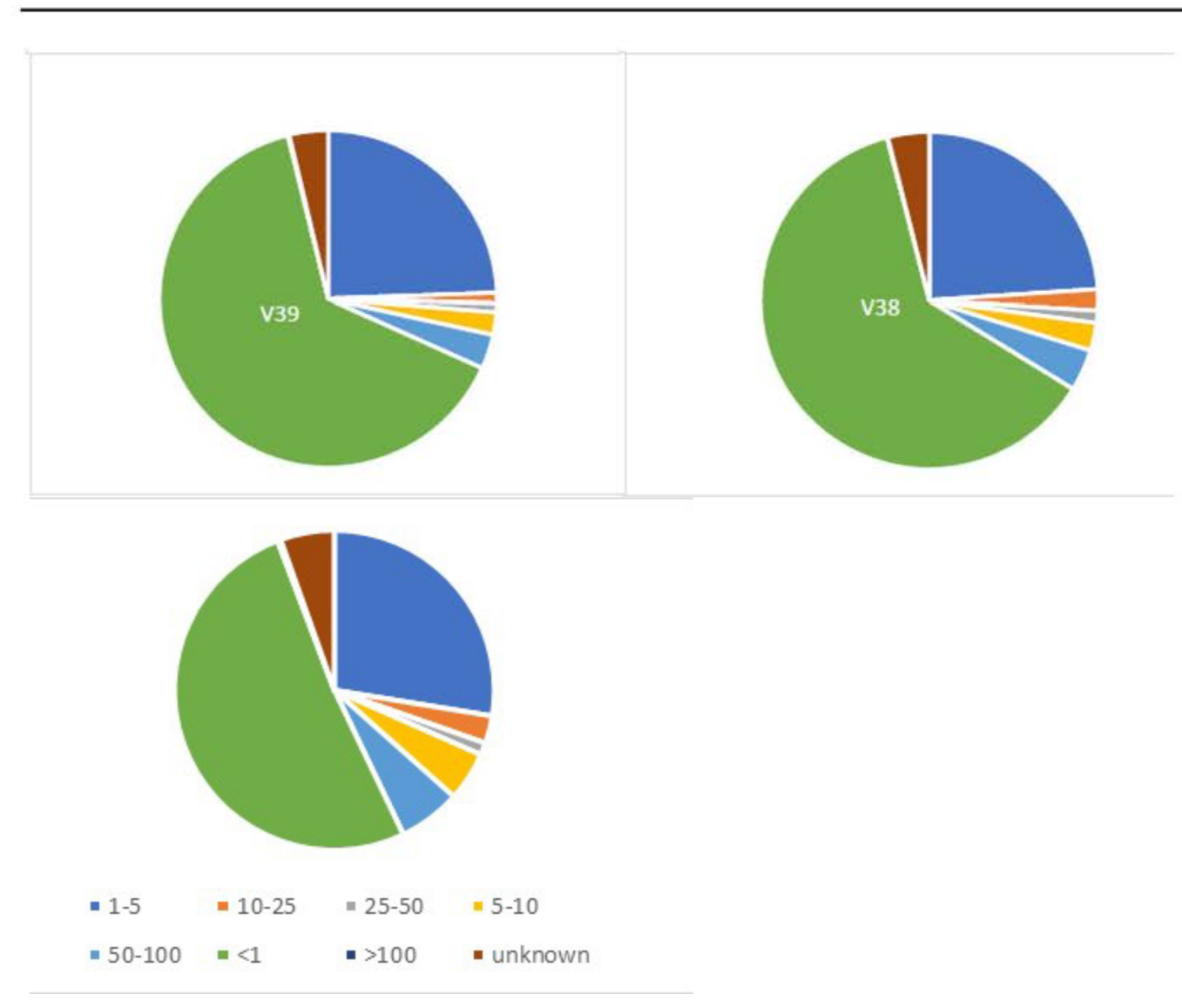

Figure 8 Spectra of the trait 'seed longevity' for the eight EUNIS habitats. Each panel of Figure 8 represents a different EUNIS habitat. The numbers represent years.

Figure 8 shows that the seed bank of the species in these habitats is predominantly short-living, that means it exists for less than one year. Habitats V38 and V39 have an even bigger part of the seedbank that is assigned to the short-living category, although more than half of the species in these habitats are perennial. In general, most habitats are dominated by annual species with a short-living seed-bank (about three-quarters with a seedbank with a longevity below 5 years).

All EUNIS habitats are mainly characterized by broadleaved plant species (Annex 6). 


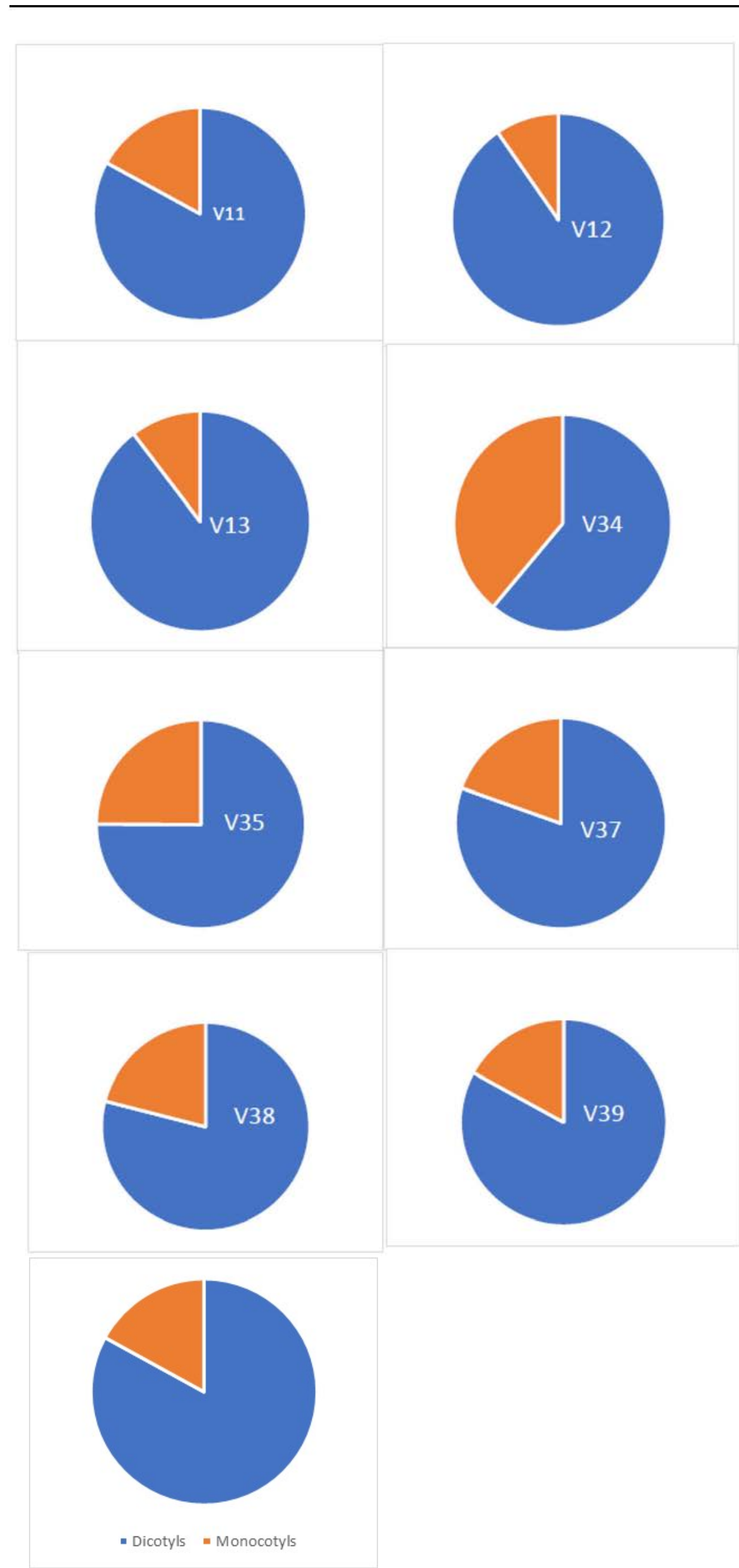

Figure 9 Spectra of the trait 'monocotyledonous / dicotyledonous' for the eight EUNIS habitats. Each panel of Figure 9 represents a different EUNIS habitat. 
Figure 9 shows that all EUNIS habitats are mainly characterized by dicotyledonous plant species. EUNIS V34 habitat has a larger contribution of monocotyledonous species. Dicotyledonous species have seeds with two embryonic leaves or cotyledons. The other group of flowering plants are monocotyledons species, typically having one cotyledon. These two groups form the two divisions of the flowering plants.

The spectra of the trait 'plant functional type' are included in Table 1. The categories C3 and C4 refer to the photosynthetic pathway of a plant. Among terrestrial plants, three photosynthetic pathways exist: C3, C4, and crassulacean acid metabolism (CAM) photosynthesis (Ehleringer \& Cerling, 2002). C3 photosynthesis is the ancestral pathway for carbon fixation and occurs in all taxonomic plant groups. It is the dominant pathway in tropical and temperate areas (Sage, 2013). The term C3 photosynthesis is based on the observation that the first product of photosynthesis is a 3-carbon molecule. In C4 photosynthesis, the initial photosynthetic product is a 4-carbon molecule. CAM and C4 photosynthesis include physiological mechanisms for concentrating $\mathrm{CO} 2$ to be re-used in photosynthesis. CAM photosynthesis is limited in its distribution and occurs in many epiphytes and succulents from very arid regions. CAM photosynthesis is not relevant in the case of the species in the selected EUNIS habitats in agricultural areas.

Table 1 Spectra for the trait 'plant functional type'. The trait scores (cumulative frequency values) are derived from quantitative data for the species present in the EUNIS habitats (counts).

\begin{tabular}{|c|c|c|}
\hline EUNIS & trait class & score \\
\hline V11 & $\mathrm{C} 3$ & 2428 \\
\hline V11 & $\mathrm{C} 4$ & 149 \\
\hline V12 & $\mathrm{C} 4$ & 145 \\
\hline V13 & $\mathrm{C} 3$ & 8103 \\
\hline V34 & $\mathrm{C} 3$ & 1016 \\
\hline V34 & $\mathrm{C} 4$ & 540 \\
\hline V35 & $\mathrm{C} 3$ & 1325 \\
\hline V35 & $\mathrm{C} 4$ & 32 \\
\hline V38 & $\mathrm{C} 4$ & 64 \\
\hline V39 & $\mathrm{C} 3$ & 1502 \\
\hline V39 & $\mathrm{C} 4$ & 10 \\
\hline
\end{tabular}

C3 is the dominant photosynthetic pathway in the terrestrial plants of the EUNIS habitats. All terrestrial EUNIS habitats also include terrestrial plants with C4 photosynthetic pathway to a lesser extent. EUNIS habitat V34 has the largest relative representativity of plant species with the C4 photosynthetic pathway. This is consistent with Figure 9, in which the EUNIS V34 habitat has a larger contribution of monocotyledonous species. 

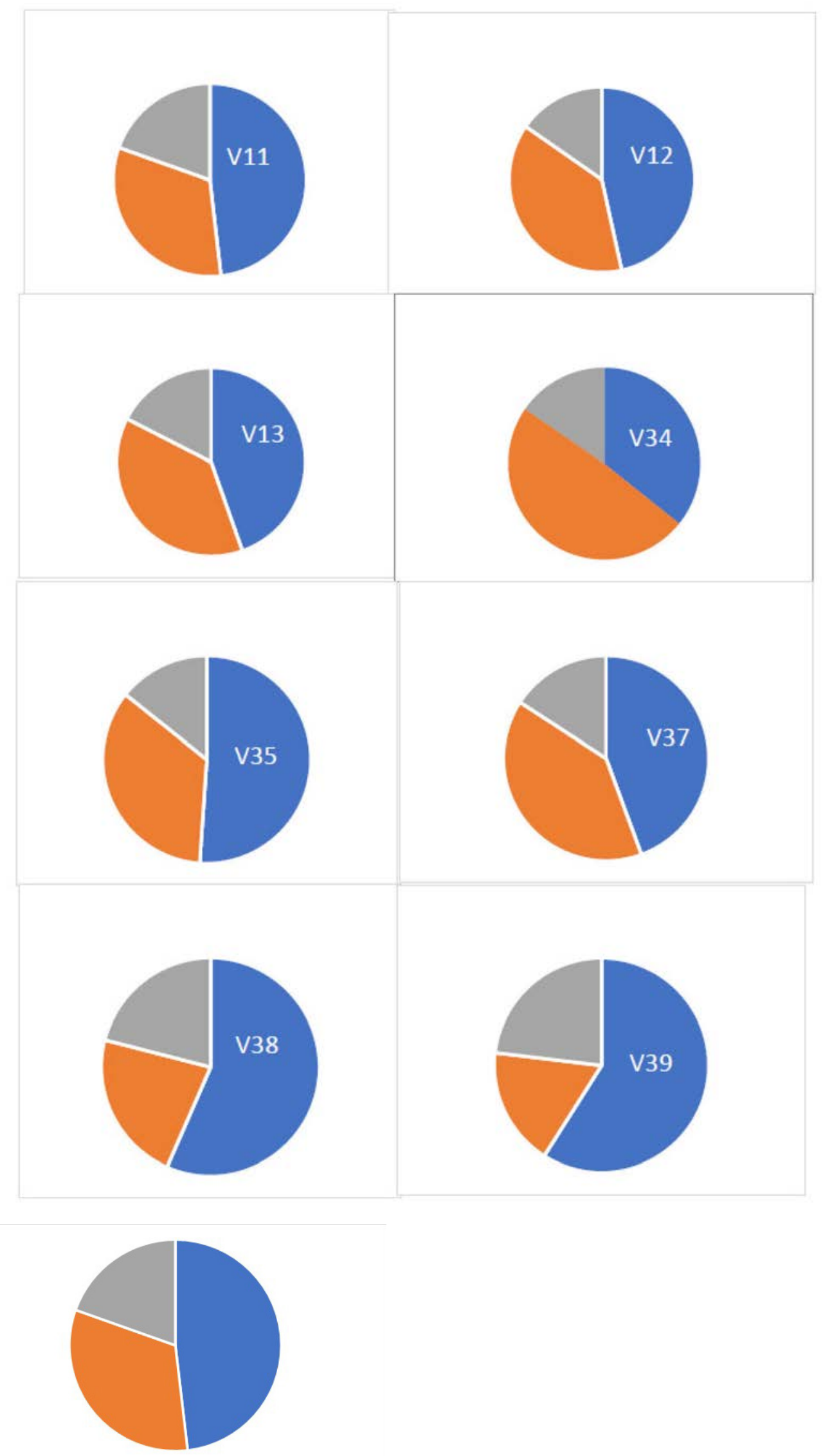

- Hemicryptophyte = Therophyte = Other

Figure 10 Spectra of the Raunkiaer life form for the eight EUNIS habitats. Each panel of Figure 10 represents a different EUNIS habitat. 
The analysis of the Raunkiaer life forms shows that two life forms are dominating the vegetation in the eight EUNIS habitats in the off-field area: the hemicryptophyte life form and the therophyte (annual) life form. Figure 10 shows that the EUNIS V34 habitat has the highest proportion of therophytes (annuals), while EUNIS habitats V38 and V39 have the highest proportion of hemicryptophyte life forms (i.e. winterbuds just above or belowground).

\subsection{Summary of traits for use in QUICKScan}

For use in QUICKScan we summarized each trait into two categories (Annex 6). Only the Raunkiaer growth form was summarized into three categories.

\subsection{Trait maps}

Annex 7 is a PDF file attached to this document. Besides the habitat suitability maps and potential occurrence maps, the annex includes trait maps for one selected trait, i.e. the trait annual - nonannual plants. Other trait maps can be generated based on the datasets delivered for this project (https://www.QUICKScan.pro). 


\section{Conclusions and discussion}

\subsection{Characterizing the off-field area}

With this study we characterized typical herbal vegetation in the off-field area. We identified eight EUNIS habitats that are relevant in the agricultural off-field area of wheat and vine crops and which could be defined in terms of plant communities, families and species (Chytrý et al., 2020; Table 1). As is shown in Chytrý et al. (2020; Table 1), not all man-made habitats can be expressed in terms of plant communities, families and species, e.g. hedgerows cannot be characterized in that way. This restricted the number of man-made habitats that could be considered in this study. The eight manmade habitats have been defined in terms of 329 species that occurred in more than $5 \%$ of the releves), belonging to 45 plant families. Up to 31 plant families occur in the EUNIS habitats that are richest in species (EUNIS habitats V12 and V13), while EUNIS habitats V34 and V35 show the lowest number of families (up to 15). Each EUNIS habitat is characterized in terms of plant species with their frequency of occurrence and their mean abundance if present in the releve.

In this project we focused on the natural vegetation in the off-field area. Grass strips were not considered as these are sown and managed by farmers. Also wooden vegetation such as hedges, tree lines and bush mixed structures were not covered in this project because of reasons explained above (phyto-sociologically not characterized), although they are considered as an important vegetation habitat in the off-field area.

In general, variation over the seasons is important when considering vegetation. This aspect was not studied in this project, as the dataset was predominantly analyzed in space (covering European scale with focus on wheat and vine crops) and not in time. It is uncertain if the dataset enables an analysis over the seasons, that means if seasonal variation can be deduced from the dataset.

The plant traits show that the off-field area is in general dominated by annual species. Only EUNIS habitats V38 and V39 are dominated by perennial species. The EUNIS habitats in general have a short-living seed bank. This is most obvious for the EUNIS habitats V38 and V39. Dicotyledonous species are dominant in the EUNIS habitats, while relatively the highest proportion of monocotyledonous species is represented in the EUNIS habitat V34. C3 is the dominant photosynthetic pathway with the exception of EUNIS habitats V34, where also the C4 photosynthetic pathway is present in a significant proportion. Hemicryptophytes and therophytes (annuals) are the dominant growth forms. Hemicryptophytes are also represented in EUNIS habitats V38 and V39, while V34 shows a lower representation of hemicryptophytes and a higher representation of therophytes (annuals).

We compared our findings with literature on traits of plants growing in field boundaries. Bergholz $(2014 ; 2016)$ found that field boundaries are dominated by competitive perennials that are adapted to high nutrient availability (based on high Ellenberg indicator value for nutrients) but that these field boundaries also contain a large proportion of (less competitive) annuals and species that occur naturally in unproductive (nutrient-poor) habitats. These results are in line with the findings of our study.

Datasets and maps were integrated and combined in the QUICKScan tool. This tool was used to generate potential occurrence maps for the eight EUNIS habitats based on habitat suitability maps and crop occurrence maps for wheat and vine.

In this study, wheat and vine crops were used as case studies. The potential occurrence maps with vine show less coverage in some parts of Europe. The vegetation plot data in these vine areas were less compared to those in agricultural wheat areas. Also, vineyards seem to be less specifically characterized in terms of specific EUNIS habitats compared to the agricultural wheat areas. 
The EUNIS habitats are habitats defined at a high aggregation level. They represent broadly defined habitats. This is considered as an appropriate approach to be applied at European level which was the focus of this study. However, as a consequence of this we conclude there is overlap in the distribution of the EUNIS habitats in Europe and there is not always a clear separation.

One of the topics intended to elaborate in this project was to describe the management of field margins and similar structures in European agricultural landscapes. Management of off-field areas might differ over Europe. Long-term research has shown that several management measures might contribute to a higher plant diversity, e.g. field margins should have at least a $5 \mathrm{~m}$ width, at water courses $10 \mathrm{~m}$, to be left unsown for self-establishment and to be mowed every second or third year (El Titi, 1999). In-depth literature search was not performed in this study, but the intention is to explore this further in future.

The characterization of the vegetation in the off-field area and the data collated in this study can be used as a basis to deduce 5 - 10 surrogate plant communities that might be used to inform the risk assessment. The characterization of these surrogate communities might include a number of traits as were quantified in this study.

\section{Conclusions in light of the research questions}

Which typical vegetation is likely to grow in the off-field area?

The off-field habitats characterized by the eight EUNIS habitats include 329 species, belong to 45 plant families and refer to 46579 vegetation plot observations in the European Vegetation Archive (for further details per EUNIS habitat see Annexes 3 - 5).

How can this vegetation be characterized by their plant traits?

- Wheat and vine off-field areas are dominated by annual species;

- Only EUNIS habitats V38 and V39 are dominated by perennial species;

- The EUNIS habitats in general have a short-living seed bank;

- Dicotyledonous species are dominant in the EUNIS habitats, while relatively the highest proportion of monocotyledonous species is represented in the EUNIS habitat V34;

- C3 is the dominant photosynthetic pathway with the exception of EUNIS habitat V34;

- Hemicryptophytes and therophytes are the dominant growth forms.

What were the experiences with the QUICKScan spatial modelling tool that was used to answer the research questions?

- QUICKScan is a scientific tool that would need more elaboration for direct application in a regulatory process (validation, standardized scenarios, etc.), however it can serve as a basis to develop potential reference tiers to be used in non-target plant risk assessment.

- Validation of outcome and methodology needs data all over Europe;

- A future development could be a combination of this tool with an effect model like IBC Grass (Reeg et al., 2017; 2018; 2020);

- Trait spectra were quantified but further extension to other traits is needed.

\subsection{Workshop with CropLife Europe}

On the $11^{\text {th }}$ and $12^{\text {th }}$ of January 2021, a workshop with CLE was held. The aim of the workshop was to explain the datasets that were used for this study as well as the background of the QUICKScan tool. The workshop was used to further shape and streamline the project as well as to raise (and if possible) answer questions. The following text reflects the discussions done during the workshop.

QUICKScan is a flexible tool. It is a modelling environment and not a fixed model. In general, it was considered as a scientific tool that needs more work to be applicable to the regulatory world. Currently it can be used as a scientific tool adding more knowledge and information in the risk assessment i.e., list of species (sensitive families) next to a crop; information on what needs to be protected in off-crop areas; from list of species derive the ones that may need to be tested further in higher tier studies; 
understanding the communities in the off-field area. Participants also expressed the need for a standardized and harmonized tool that would be easy to use and understand for risk assessors and regulators.

It was questioned if and to what extend the tool needs validation. The focus of the current study was on European level. That means that one study in an off-field area is not sufficient as a case study to validate the outcome of the study. A lot more field data all over Europe and in different climate zones are needed to perform such a validation.

It was also suggested that for the future the QUICKScan tool could be combined with an effect model like IBC Grass (Reeg et al., 2017; 2018; 2020). IBC grass is a spatially explicit and individual-based plant community model that was originally designed to test the response of plant communities to different disturbances such as grazing (Reeg et al., 2018). The IBC model was modified to model the effects of herbicides on a number of terrestrial plant species in a community setting using endpoints as generated in toxicity tests.

It was recommended to add other traits. We agree that the number of traits we could use was limited by the available data. We could use data of 5 traits for the 329 species we identified as being part of the EUNIS habitats in the off-field area. During the workshop possible additional traits were suggested such as growth form (e.g., rosette, erect), plant size, competitor vs. non-competitor (e.g., nutrient requirements); reproduction type (e.g., seeds, stolon etc.). As a follow-up action, the Raunkiaer growth forms were added to the database and report.

The long-term target of the exercise was to use the predictions of plant communities and traits as outcome of this project as a reference tier in the risk assessment. The whole project was seen as a step towards the description of a reference tier.

\section{Conclusions from the workshop (summarized from workshop report)}

Starting as an exploratory tool, there is still considerable work needed for generating a risk assessment tool. The QUICKScan tool is very transparent (merging GIS and databases together), which was considered as an advantage in the regulatory risk assessment by participants. It was considered as a powerful approach. However, it needs to be more standardized with fixed rules if it is intended to be used as a tool in risk assessment. The workflow and linkages would need to be more robust because at the moment there are limited databases on the traits linked to the tool. More research work may be required to address the 'how' and understand better what the key questions should be.

Although transparency is important, the tool is too open to individuals who can make alterations with no justifications. Actually, the regulatory community may not have the skills to use the tool and so more work is needed to make it simpler. The QUICKScan tool can be used as a dynamic modelling environment to focus on specific crops, on specific crop areas, climate zones or regions. The tool can be downloaded (https://www.QUICKScan.pro/download) where also an instruction manual is available.

Traits database would need more elaboration and traits need to be re-considered. We need to be able to incorporate more crops to choose from in the tool, so the databases would need to be reviewed. There was also a wish for adding temporal aspects, e.g., different growth stages at different seasons. 


\section{References}

Bergholz, K., 2014. Species composition of herbaceous plant communities occurring in agricultural regions in Europe. Report Plant Ecology and Nature Conservation, University of Potsdam. 186 pp.

Bergholz, K., 2016. Follow-up study to species composition of herbaceous plant communities occurring in agricultural regions in Europe. Report Plant Ecology and Nature Conservation, University of Potsdam. 86 pp.

Chytrý M., Hennekens S.M., Jiménez-Alfaro, B., Knollová, I., Dengler, J., Jansen, F., Landucci, F., Schaminée, J.H.J. et al., 2016. European Vegetation Archive (EVA): an integrated database of European vegetation plots. Applied Vegetation Science 19: 173-180.

Chytrý M. et al. 2016. European Vegetation Archive (EVA): an integrated database of European vegetation plots. Applied Vegetation Science 19: 173-180. https://onlinelibrary.wiley.com/doi/full/10.1111/avsc. 12191

Chytrý M. et al., 2020. EUNIS habitat classification: Expert system, characteristic species combinations and distribution maps of European habitats. Appl. Veg. Sci. 2020;00:1-28.

Elith, J., J., Phillips, S. J., Hastie, T., Dudíte, M., Chee, Y. E. \& Yates, C. J., 2011. A statistical explanation of MaxEnt for ecologists. Diversity and Distributions, 17: 43-57.

Ehleringer, J. E. and T. E. Cerling, 2002. C3 and C4 Photosynthesis. In: Volume 2, The Earth system: biological and ecological dimensions of global environmental change, pp 186-190 (Eds.

H. A. Mooney and J. G. Canadell). Encyclopedia of Global Environmental Change (ISBN 0-47197796-9). John Wiley \& Sons, Ltd, Chichester, 2002

Hennekens, 2020 Distribution and habitat suitability maps of revised EUNIS vegetated man-made habitats. Task $n^{\circ}:$ 1.7.5.1. Report ETC/BD.

Kattge, J, Boenisch, G, Diaz, S, et al. TRY plant trait database - enhanced coverage and open access. Glob Change Biol. 2020; 26: 119-188. https://doi.org/10.1111/gcb.14904

Mucina, L., Helga Bültmann, Klaus Dierßen, Jean-Paul Theurillat, Thomas Raus, Andraž Čarni, Kateřina Šumberová, Wolfgang Willner,Jürgen Dengler, Rosario Gavilán García, Milan Chytrý, Michal Hájek, Romeo Di Pietro, Dmytro Iakushenko, Jens Pallas, Fred J.A. Daniëls, Erwin Bergmeier, Arnoldo Santos Guerra, Nikolai Ermakov, Milan Valachovič, Joop H.J. Schaminée, Tatiana Lysenko, Yakiv P. Didukh,Sandro Pignatti, John S. Rodwell, Jorge Capelo, Heinrich E. Weber, Ayzik Solomeshch, Panayotis Dimopoulos, Carlos Aguiar, Stephan M. Hennekens, Lubomír Tichý 2016.Vegetation of Europe: Hierarchical floristic classification system of vascular plant, bryophyte, lichen, and algal communities. Applied Vegetation Science 19 (Suppl. 1): 3-264.

Phillips, S.J., R.P. Anderson \& R.E. Schapire, 2006. Maximum entropy modeling of species geographic distributions. Ecological Modelling 190: 231-259.

Reeg, J., Heine, S., Mihan, C., McGee, S., Preuss, T.G., Jeltsch, F., 2020. Herbicide risk assessments of non-target terrestrial plant communities: A graphical user interface for the plant community model IBC-grass. PLoS ONE, 15 (3),

Reeg, J., Heine, S., Mihan, C., McGee, S., Preuss, T.G., Jeltsch, F., 2018. Simulation of herbicide impacts on a plant community: comparing model predictions of the plant community model IBCgrass to empirical data. Environmental Sciences Europe, 30 (1), art. no. 44.

Reeg, J., Schad, T., Preuss, T.G., Solga, A., Körner, K., Mihan, C., Jeltsch, F., 2017. Modelling direct and indirect effects of herbicides on non-target grassland communities. Ecological Modelling, 348, pp. 44-55.

Sage, R.F., 2013. Photorespiratory compensation: a driver for biological diversity. Plant Biology 15(4) Special Issue: p. 624-638 DOI: 10.1111/plb.12024.

Schaminée, Joop H.J., M. Chytrý, S. M. Hennekens, J. A.M. Janssen, I. Knollová, Z. Lososová, C. Marcenò, L. Tichý and data providers, 2020. Updated crosswalks, formal query routines and indicator species of the revised EUNIS Habitat Classification with the European Vegetation Classification for vegetated man-made habitats and alligning of crosswalks between European Red List habitats and Annex I habitats with crosswalks between EUNIS habitats and Annex I habitats. 3417/B2019/EEA6 Framework Contract: EEA/NSS/17/002/Lot 1. 46 pp. 
Schaminée, J.H.J., Chytrý, M., Dengler, J., Hennekens, S.M., Janssen, J.A.M., Jiménez-Alfaro, B., Knollová, I., Landucci, F., Marcenò, C., Rodwell, J.S., Tichý, L. \& data-providers (2016b).

Development of distribution maps of grassland habitats of EUNIS habitat classification. Report to the European Environmental Agency (EEA/NSV/16/005). Alterra WUR, Wageningen, the Netherlands.

Schaminée, J.H.J., Chytrý, M., Hennekens, S.M., Janssen, J.A.M., Knollová, I., Rodwell, J.S., Tichý, L. \& data-providers, 2018. Updated crosswalk of the revised EUNIS Habitat Classification with the European vegetation classification and indicator species for the EUNIS grassland, shrubland and forest types. Report to the European Environmental Agency (EEA/NSS/17/002/Lot 1). Alterra WUR, Wageningen, the Netherlands.

Verweij, P., S. Janssen, L. Braat, M. van Eupen, M. Pérez Soba, M. Winograd, W. de Winter, A. Cormont, 2016. QUICKScan as a quick and participatory methodology for problem identification and scoping in policy processes. Environmental Science \& Policy 66 (2016) 47-61. 


\section{Annex 1 Predictors for habitat suitability modelling}

\section{Climate}

- Potential Evapotranspiration

https://cgiarcsi.community/data/global-aridity-and-pet-database/

- Solar radiation

http://www. worldgrids.org/doku.php?id=wiki:inmsre3

- Temperature Seasonality (standard deviation *100)

https://www.worldclim.org/bioclim

- Mean Temperature of Wettest Quarter

https://www.worldclim.org/bioclim

- Annual Precipitation

https://www.worldclim.org/bioclim

- Precipitation Seasonality (Coefficient of Variation)

https://www.worldclim.org/bioclim

- Precipitation of Warmest Quarter

https://www.worldclim.org/bioclim

- Solar radiation ( $\times 365 / 8 \mathrm{kWh} \mathrm{m-2)}$

www.worldgrids.org

- Potential Evapotranspiration (mm yr-1)

https://cgiarcsi.community/data/global-aridity-and-pet-database/

\section{Topography}

- Distance to water (rivers, lakes, sea)

derived from the shapefile 'Inland_Waters.shp'

- Digital Elevation Map (DEM)

\section{Soil}

- Bulk density of the soil $\left(\mathrm{kg} / \mathrm{m}^{3}\right)$

Hengl et al. 2014

https://soilgrids.org/

- Cation Exchange Capacity of the soil

Hengl et al. 2014

https://soilgrids.org/

- Weight in \% of clay particles $(<0.0002 \mathrm{~mm}$ )

Hengl et al. 2014

https://soilgrids.org/

- Volume \% of coarse fragments (> $2 \mathrm{~mm}$ )

Hengl et al. 2014

https://soilgrids.org/

- Soil organic carbon content (\%o)

Hengl et al. 2014

https://soilgrids.org/

- Soil pH (water)

Hengl et al. 2014

https://soilgrids.org/

- Weight in \% of silt particles (0.0002-0.05 mm)

Hengl et al. 2014

https://soilgrids.org/

- Weight in \% of sand particles (0.05-2 mm)

Hengl et al. 2014

https://soilgrids.org/ 


\section{RS-EBV's}

- Land Use Land Cover (LULC) https://land.copernicus.eu/pan-european/corine-land-cover

- Inundation; occurrence Global Surface Water Explorer, 1984-2015, 30m, resampled to $1 \mathrm{~km}$ (resampling methods: average resampling and mode resampling (selects the value which appears most often of all the sampled points))

- Phenology; End of Season (day number) End of Season, defined as the point in time where the NDVI drops below the NDVI at the start of the growing season

- Phenology; Length of season (days) Length of season, number of days between EoS and Sos [days]

- Phenology; Low of season (day number) Phenology; Low of season (day number with lowest NDVI)

- Phenology; NDVI mean Mean NDVI [0..10000]

- Phenology; NDVI seasonality Minimum NDVI [0..10000]

- Phenology; Peak of season (day number) Phenology; Peak of season (day number with highest NDVI)

- Phenology; Start of Season (day number) Start of Season, defined as the point in the year with the largest positive rate of change (maximum of 1 st derivative) [day of year 1...365]

- Vegetation height (m) 3D Global Vegetation Map, 2000, $1 \mathrm{~km}$

\section{Anthropogenic}

- Population density 2018

https://landscan.ornl.gov/ 


\section{Annex 2 References of original individual datasets in TRY}

\begin{tabular}{|c|c|c|}
\hline \multicolumn{2}{|l|}{ Data owner } & Dataset \\
\hline Albrecht & Harald & Seed Longevity of European Early Successional Species \\
\hline Atkin & Owen & Plant Physiology Database \\
\hline Atkin & Owen & Global Respiration Database \\
\hline Baldocchi & Dennis & Photosynthesis Traits Database \\
\hline Biological Records & Centre (BRC) & PLANTATT - Attributes of British and Irish Plants \\
\hline Blonder & Benjamin & Leaf Structure, Venation and Economic Spectrum \\
\hline Bruelheide & Helge & Trait and biomass data 2014 and 2015 of the BE_LOW project \\
\hline Bucher & Solveig Franziska & Garmisch-Partenkirchen elevational gradients \\
\hline Burrascano & Sabina & Plant Traits from Circeo National Park, Italy \\
\hline Cerabolini & Bruno E. L. & Leaf Structure and Economics Spectrum \\
\hline Cerabolini & Bruno E. L. & Flora d'Italia Functional Traits Hoard (FIFTH) \\
\hline Cerabolini & Bruno E. L. & Malga San Simone Trait Database (MSS) \\
\hline Ciccarelli & Daniela & Mediterranean psammophytes \\
\hline Cornelissen & Johannes & Abisko \& Sheffield Database \\
\hline Cornelissen & Johannes & Sheffield Database \\
\hline Craine & Joseph & Global 15N Database \\
\hline Dainese & Matteo & Italian Alps Plant Traits Database \\
\hline de Frutos & Angel & Cabo de Gata-Níjar Natural Park \\
\hline Díaz & Sandra & Sheffield-Iran-Spain Database \\
\hline Dwyer & John & Specific leaf area responses to environmental gradients through space and time \\
\hline Engemann & Kristine & Plant growth form dataset for the New World \\
\hline Fan Reinfelder & Ying & Global Dataset of Maximum Rooting Depth \\
\hline Flores & Olivier & Categorical Plant Traits Database \\
\hline Flowers & Tim & eHALOPH - Halophytes Database (2015) \\
\hline Flowers & Tim & eHALOPH - Halophytes Database (2018) \\
\hline Ford & Henry & Ecological Flora of the British Isles \\
\hline Forey & Estelle & Plant Coastal Dune Traits (France, Aquitaine) \\
\hline Gachet & Sophie & BASECO: a floristic and ecological database of Mediterranean French flora \\
\hline Gallagher & Rachael & Climbing Plants Trait Database \\
\hline Gallagher & Rachael & Climbing plants trait dataset \\
\hline Günther & Angela & TRY Categorical Traits Dataset (update 2018) \\
\hline Higgins & Steve & Dispersal Traits Database \\
\hline Iversen & Colleen & FRED - Fine Root Ecology Database \\
\hline Jackson & Robert & Nutrient Resorption Efficiency Database \\
\hline Jansen & Steven & Xylem Functional Traits (XFT) Database \\
\hline Jansen & Steven & Leaf element composition of ferns and lycophytes \\
\hline Kattenborn & Teja & KIT herbaceous functional gradient (median) \\
\hline Kattge & Jens & Leaf Physiology Database \\
\hline Kleyer & Michael & The LEDA Traitbase \\
\hline Klimesova & Jitka & CLO-PLA : a Database of Clonal Growth in Plants \\
\hline Kühn & Ingolf & BiolFlor Database \\
\hline La Pierre & Kim & Plant traits of grassland species \\
\hline Lanta & Vojtech & Meadow Plant Traits: Biomass Allocation, Rooting depth \\
\hline $\mathrm{Li}$ & Yuanzhi & Sherbrooke \\
\hline Lin & Yan-Shih & Global Leaf Gas Exchange Database (I) \\
\hline Maire & Vincent & Photosynthesis Traits Worldwide \\
\hline Mehrabi & Zia & Shoot dry mass of annual grassland species \\
\hline Mencuccini & Maurizio & Whole Plant Hydraulic Conductance \\
\hline Milla & Ruben & Altitudinal Vicariants Spain \\
\hline Minden & Vanessa & Antibiotics-effects on plant traits \\
\hline Minden & Vanessa & Antibiotics-effects on plant elements \\
\hline Moles & Angela & Global Seed Mass, Plant Height Database \\
\hline Moretti & Marco & Traits from the Wildfire Project \\
\hline Ollerer & Kinga & Plant Traits from Romania \\
\hline Onoda & Yusuke & Leaf Biomechanics Database \\
\hline Onoda & Yusuke & Onoda 2017 leaf dataset \\
\hline Ordonez & Jenny & The Netherlands Plant Traits Database \\
\hline Otto & Sarah & Tree of sex: a database of sexual systems \\
\hline
\end{tabular}




$\begin{array}{lll}\text { Pärtel } & \text { Meelis } & \text { Grassland Plant Trait Database } \\ \text { Pausas } & \text { Juli } & \text { BROT Plant Trait Database } \\ \text { Peco } & \text { Begoña } & \text { Plant Traits of Acidic Grasslands in Central Spain } \\ \text { Poorter } & \text { Hendrik } & \text { Categorical Plant Traits Database } \\ \text { Poschlod } & \text { Peter } & \text { BIOPOP: Functional Traits for Nature Conservation } \\ \text { Reich } & \text { Peter } & \text { Reich-Oleksyn Global Leaf N, P Database } \\ \text { Reich } & \text { Peter } & \text { Global Respiration Database } \\ \text { Rolo Romero } & \text { Victor } & \text { Leaf nutrient concentrations } \\ \text { Schweingruber } & \text { Fritz } & \text { The Xylem/Phloem Database } \\ \text { Semchenko } & \text { Marina } & \text { Aboveground morphological traits of grassland species } \\ \text { Sheremetev } & \text { Serge } & \text { Herbs Water Relations on Soil Moisture Gradients } \\ \text { Sheremetev } & \text { Serge } & \text { The Global Leaf Traits } \\ \text { Shipley } & \text { Bill } & \text { Leaf and Whole Plant Traits Database } \\ \text { van Bodegom } & \text { Peter } & \text { Categorical Plant Traits Database } \\ \text { Vassilev } & \text { Kiril } & \text { Functional Traits Of Bulgarian Grasslands } \\ \text { Walker } & \text { Anthony } & \text { A Global Data Set of Leaf Photosynthetic Rates, Leaf N and P, and Specific Leaf Area } \\ \text { Werner } & \text { Gijsbert } & \text { Mycorrhizal Association Database } \\ \text { White } & \text { Michael } & \text { BIOME-BGC Parameterization Database } \\ \text { Wirth } & \text { Christian } & \text { The Functional Ecology of Trees (FET) Database - Jena } \\ \text { Wright } & \text { Ian } & \text { Categorical Plant Traits Database } \\ \text { Wright } & \text { Ian } & \text { GLOPNET - Global Plant Trait Network Database } \\ \text { Wright } & \text { Ian } & \text { Global leaf size dataset }\end{array}$




\section{Annex 3 Plant families per EUNIS habitat}

\begin{tabular}{|c|c|c|c|}
\hline EUNIS & EUNISName & Family & SUM \\
\hline V11 & Intensive unmixed crops & Amaranthaceae & 11 \\
\hline V11 & Intensive unmixed crops & Apiaceae & 22 \\
\hline V11 & Intensive unmixed crops & Boraginaceae & 18 \\
\hline V11 & Intensive unmixed crops & Brassicaceae & 65 \\
\hline V11 & Intensive unmixed crops & Caryophyllaceae & 61 \\
\hline V11 & Intensive unmixed crops & Chenopodiaceae & 32 \\
\hline V11 & Intensive unmixed crops & Compositae & 213 \\
\hline V11 & Intensive unmixed crops & Convolvulaceae & 29 \\
\hline V11 & Intensive unmixed crops & Equisetaceae & 14 \\
\hline V11 & Intensive unmixed crops & Euphorbiaceae & 11 \\
\hline V11 & Intensive unmixed crops & Fabaceae & 119 \\
\hline V11 & Intensive unmixed crops & Geraniaceae & 16 \\
\hline V11 & Intensive unmixed crops & Hypericacaea & 7 \\
\hline V11 & Intensive unmixed crops & Lamiaceae & 31 \\
\hline V11 & Intensive unmixed crops & Linaceae & 5 \\
\hline V11 & Intensive unmixed crops & Paniceae & 14 \\
\hline V11 & Intensive unmixed crops & Papaveraceae & 15 \\
\hline V11 & Intensive unmixed crops & Plantaginaceae & 60 \\
\hline V11 & Intensive unmixed crops & Poaceae & 173 \\
\hline V11 & Intensive unmixed crops & Polygonaceae & 99 \\
\hline V11 & Intensive unmixed crops & Primulaceae & 11 \\
\hline V11 & Intensive unmixed crops & Ranunculaceae & 13 \\
\hline V11 & Intensive unmixed crops & Rosaceae & 13 \\
\hline V11 & Intensive unmixed crops & Rubiaceae & 24 \\
\hline V11 & Intensive unmixed crops & Violaceae & 23 \\
\hline V12 & Mixed crops of market gardens and horticulture & Amaranthaceae & 34 \\
\hline V12 & Mixed crops of market gardens and horticulture & Apiaceae & 94 \\
\hline V12 & Mixed crops of market gardens and horticulture & Boraginaceae & 42 \\
\hline V12 & Mixed crops of market gardens and horticulture & Brassicaceae & 139 \\
\hline V12 & Mixed crops of market gardens and horticulture & Caryophyllaceae & 108 \\
\hline V12 & Mixed crops of market gardens and horticulture & Chenopodiaceae & 76 \\
\hline V12 & Mixed crops of market gardens and horticulture & Compositae & 390 \\
\hline V12 & Mixed crops of market gardens and horticulture & Convolvulaceae & 43 \\
\hline V12 & Mixed crops of market gardens and horticulture & Cucurbitaceae & 6 \\
\hline V12 & Mixed crops of market gardens and horticulture & Cucurbitaceaea & 5 \\
\hline V12 & Mixed crops of market gardens and horticulture & Equisetaceae & 26 \\
\hline V12 & Mixed crops of market gardens and horticulture & Euphorbiaceae & 33 \\
\hline V12 & Mixed crops of market gardens and horticulture & Fabaceae & 151 \\
\hline V12 & Mixed crops of market gardens and horticulture & Geraniaceae & 34 \\
\hline V12 & Mixed crops of market gardens and horticulture & Lamiaceae & 84 \\
\hline V12 & Mixed crops of market gardens and horticulture & Malvaceae & 7 \\
\hline V12 & Mixed crops of market gardens and horticulture & Oxalidaceae & 8 \\
\hline V12 & Mixed crops of market gardens and horticulture & Paniceae & 23 \\
\hline V12 & Mixed crops of market gardens and horticulture & Papaveraceae & 28 \\
\hline V12 & Mixed crops of market gardens and horticulture & Plantaginaceae & 124 \\
\hline V12 & Mixed crops of market gardens and horticulture & Poaceae & 175 \\
\hline V12 & Mixed crops of market gardens and horticulture & Polygonaceae & 196 \\
\hline V12 & Mixed crops of market gardens and horticulture & Portulacaceae & 8 \\
\hline V12 & Mixed crops of market gardens and horticulture & Primulaceae & 23 \\
\hline V12 & Mixed crops of market gardens and horticulture & Ranunculaceae & 27 \\
\hline V12 & Mixed crops of market gardens and horticulture & Resedaceaea & 5 \\
\hline V12 & Mixed crops of market gardens and horticulture & Rosaceae & 25 \\
\hline
\end{tabular}




\begin{tabular}{|c|c|c|c|}
\hline EUNIS & EUNISName & Family & SUM \\
\hline V12 & Mixed crops of market gardens and horticulture & Rubiaceae & 36 \\
\hline V12 & Mixed crops of market gardens and horticulture & Solanaceae & 44 \\
\hline V12 & Mixed crops of market gardens and horticulture & Triticeae & 11 \\
\hline V12 & Mixed crops of market gardens and horticulture & Urticaceae & 19 \\
\hline V12 & Mixed crops of market gardens and horticulture & Violaceae & 34 \\
\hline V13 & Arable land with unmixed crops grown by low-intensity agricultural methods & Amaranthaceae & 5 \\
\hline V13 & Arable land with unmixed crops grown by low-intensity agricultural methods & Apiaceae & 46 \\
\hline V13 & Arable land with unmixed crops grown by low-intensity agricultural methods & Boraginaceae & 83 \\
\hline V13 & Arable land with unmixed crops grown by low-intensity agricultural methods & Brassicaceae & 174 \\
\hline V13 & Arable land with unmixed crops grown by low-intensity agricultural methods & Campanulaceae & 12 \\
\hline V13 & Arable land with unmixed crops grown by low-intensity agricultural methods & Caryophyllaceae & 203 \\
\hline V13 & Arable land with unmixed crops grown by low-intensity agricultural methods & Chenopodiaceae & 38 \\
\hline V13 & Arable land with unmixed crops grown by low-intensity agricultural methods & Compositae & 340 \\
\hline V13 & Arable land with unmixed crops grown by low-intensity agricultural methods & Convolvulaceae & 50 \\
\hline V13 & Arable land with unmixed crops grown by low-intensity agricultural methods & Equisetaceae & 37 \\
\hline V13 & Arable land with unmixed crops grown by low-intensity agricultural methods & Euphorbiaceae & 25 \\
\hline V13 & Arable land with unmixed crops grown by low-intensity agricultural methods & Fabaceae & 156 \\
\hline V13 & Arable land with unmixed crops grown by low-intensity agricultural methods & Geraniaceae & 29 \\
\hline V13 & Arable land with unmixed crops grown by low-intensity agricultural methods & Juncaceae & 9 \\
\hline V13 & Arable land with unmixed crops grown by low-intensity agricultural methods & Lamiaceae & 64 \\
\hline V13 & Arable land with unmixed crops grown by low-intensity agricultural methods & Oxalidaceae & 9 \\
\hline V13 & Arable land with unmixed crops grown by low-intensity agricultural methods & Paniceae & 6 \\
\hline V13 & Arable land with unmixed crops grown by low-intensity agricultural methods & Papaveraceae & 67 \\
\hline V13 & Arable land with unmixed crops grown by low-intensity agricultural methods & Plantaginaceae & 117 \\
\hline V13 & Arable land with unmixed crops grown by low-intensity agricultural methods & Poaceae & 185 \\
\hline V13 & Arable land with unmixed crops grown by low-intensity agricultural methods & Polygonaceae & 178 \\
\hline V13 & Arable land with unmixed crops grown by low-intensity agricultural methods & Primulaceae & 38 \\
\hline V13 & Arable land with unmixed crops grown by low-intensity agricultural methods & Ranunculaceae & 49 \\
\hline V13 & Arable land with unmixed crops grown by low-intensity agricultural methods & Rosaceae & 31 \\
\hline V13 & Arable land with unmixed crops grown by low-intensity agricultural methods & Rubiaceae & 53 \\
\hline V13 & Arable land with unmixed crops grown by low-intensity agricultural methods & Solanaceae & 10 \\
\hline V13 & Arable land with unmixed crops grown by low-intensity agricultural methods & Triticeae & 68 \\
\hline V13 & Arable land with unmixed crops grown by low-intensity agricultural methods & Valerianaceae & 9 \\
\hline V13 & Arable land with unmixed crops grown by low-intensity agricultural methods & Violaceae & 65 \\
\hline V34 & Trampled xeric grassland with annuals & Amaranthaceae & 38 \\
\hline V34 & Trampled xeric grassland with annuals & Brassicaceae & 27 \\
\hline V34 & Trampled xeric grassland with annuals & Caryophyllaceae & 14 \\
\hline V34 & Trampled xeric grassland with annuals & Chenopodiaceae & 26 \\
\hline V34 & Trampled xeric grassland with annuals & Compositae & 82 \\
\hline V34 & Trampled xeric grassland with annuals & Convolvulaceae & 20 \\
\hline V34 & Trampled xeric grassland with annuals & Euphorbiaceae & 12 \\
\hline V34 & Trampled xeric grassland with annuals & Fabaceae & 16 \\
\hline V34 & Trampled xeric grassland with annuals & Paniceae & 12 \\
\hline V34 & Trampled xeric grassland with annuals & Plantaginaceae & 42 \\
\hline V34 & Trampled xeric grassland with annuals & Poaceae & 225 \\
\hline V34 & Trampled xeric grassland with annuals & Polygonaceae & 50 \\
\hline V34 & Trampled xeric grassland with annuals & Portulacaceae & 29 \\
\hline V34 & Trampled xeric grassland with annuals & Solanaceae & 7 \\
\hline V34 & Trampled xeric grassland with annuals & Zygophyllaceae & 9 \\
\hline V35 & Trampled mesophilous grassland with annuals & & 6 \\
\hline V35 & Trampled mesophilous grassland with annuals & Brassicaceae & 61 \\
\hline V35 & Trampled mesophilous grassland with annuals & Bryophyta & 17 \\
\hline V35 & Trampled mesophilous grassland with annuals & Caryophyllaceae & 34 \\
\hline V35 & Trampled mesophilous grassland with annuals & Chenopodiaceae & 10 \\
\hline V35 & Trampled mesophilous grassland with annuals & Compositae & 144 \\
\hline V35 & Trampled mesophilous grassland with annuals & Convolvulaceae & 5 \\
\hline V35 & Trampled mesophilous grassland with annuals & Fabaceae & 33 \\
\hline V35 & Trampled mesophilous grassland with annuals & Juncaceae & 5 \\
\hline
\end{tabular}




\begin{tabular}{|c|c|c|c|}
\hline EUNIS & EUNISName & Family & SUM \\
\hline V35 & Trampled mesophilous grassland with annuals & Malvaceae & 5 \\
\hline V35 & Trampled mesophilous grassland with annuals & Plantaginaceae & 82 \\
\hline V35 & Trampled mesophilous grassland with annuals & Poaceae & 148 \\
\hline V35 & Trampled mesophilous grassland with annuals & Polygonaceae & 76 \\
\hline V35 & Trampled mesophilous grassland with annuals & Ranunculaceae & 5 \\
\hline V35 & Trampled mesophilous grassland with annuals & Rosaceae & 5 \\
\hline V37 & Annual anthropogenic herbaceous vegetation & Amaranthaceae & 60 \\
\hline V37 & Annual anthropogenic herbaceous vegetation & Apiaceae & 7 \\
\hline V37 & Annual anthropogenic herbaceous vegetation & Brassicaceae & 78 \\
\hline V37 & Annual anthropogenic herbaceous vegetation & Caryophyllaceae & 19 \\
\hline V37 & Annual anthropogenic herbaceous vegetation & Chenopodiaceae & 54 \\
\hline V37 & Annual anthropogenic herbaceous vegetation & Compositae & 207 \\
\hline V37 & Annual anthropogenic herbaceous vegetation & Convolvulaceae & 37 \\
\hline V37 & Annual anthropogenic herbaceous vegetation & Equisetaceae & 7 \\
\hline V37 & Annual anthropogenic herbaceous vegetation & Fabaceae & 15 \\
\hline V37 & Annual anthropogenic herbaceous vegetation & Geraniaceae & 14 \\
\hline V37 & Annual anthropogenic herbaceous vegetation & Lamiaceae & 7 \\
\hline V37 & Annual anthropogenic herbaceous vegetation & Malvaceae & 20 \\
\hline V37 & Annual anthropogenic herbaceous vegetation & Paniceae & 16 \\
\hline V37 & Annual anthropogenic herbaceous vegetation & Papaveraceae & 6 \\
\hline V37 & Annual anthropogenic herbaceous vegetation & Plantaginaceae & 28 \\
\hline V37 & Annual anthropogenic herbaceous vegetation & Poaceae & 149 \\
\hline V37 & Annual anthropogenic herbaceous vegetation & Polygonaceae & 56 \\
\hline V37 & Annual anthropogenic herbaceous vegetation & Portulacaceae & 8 \\
\hline V37 & Annual anthropogenic herbaceous vegetation & Rubiaceae & 8 \\
\hline V37 & Annual anthropogenic herbaceous vegetation & Solanaceae & 20 \\
\hline V37 & Annual anthropogenic herbaceous vegetation & Urticaceae & 21 \\
\hline V37 & Annual anthropogenic herbaceous vegetation & Verbenaveae & 6 \\
\hline V38 & Dry perennial anthropogenic herbaceous vegetation & Anacardiaceaea & 6 \\
\hline V38 & Dry perennial anthropogenic herbaceous vegetation & Apiaceae & 32 \\
\hline V38 & Dry perennial anthropogenic herbaceous vegetation & Boraginaceae & 16 \\
\hline V38 & Dry perennial anthropogenic herbaceous vegetation & Brassicaceae & 22 \\
\hline V38 & Dry perennial anthropogenic herbaceous vegetation & Caryophyllaceae & 23 \\
\hline V38 & Dry perennial anthropogenic herbaceous vegetation & Chenopodiaceae & 12 \\
\hline V38 & Dry perennial anthropogenic herbaceous vegetation & Compositae & 300 \\
\hline V38 & Dry perennial anthropogenic herbaceous vegetation & Convolvulaceae & 30 \\
\hline V38 & Dry perennial anthropogenic herbaceous vegetation & Cyperaceae & 5 \\
\hline V38 & Dry perennial anthropogenic herbaceous vegetation & Equisetaceae & 9 \\
\hline V38 & Dry perennial anthropogenic herbaceous vegetation & Euphorbiaceae & 12 \\
\hline V38 & Dry perennial anthropogenic herbaceous vegetation & Fabaceae & 75 \\
\hline V38 & Dry perennial anthropogenic herbaceous vegetation & Hypericacaea & 13 \\
\hline V38 & Dry perennial anthropogenic herbaceous vegetation & Lamiaceae & 10 \\
\hline V38 & Dry perennial anthropogenic herbaceous vegetation & Malvaceae & 5 \\
\hline V38 & Dry perennial anthropogenic herbaceous vegetation & Onagraceae & 5 \\
\hline V38 & Dry perennial anthropogenic herbaceous vegetation & Plantaginaceae & 40 \\
\hline V38 & Dry perennial anthropogenic herbaceous vegetation & Poaceae & 182 \\
\hline V38 & Dry perennial anthropogenic herbaceous vegetation & Polygonaceae & 24 \\
\hline V38 & Dry perennial anthropogenic herbaceous vegetation & Ranunculaceae & 5 \\
\hline V38 & Dry perennial anthropogenic herbaceous vegetation & Resedaceaea & 6 \\
\hline V38 & Dry perennial anthropogenic herbaceous vegetation & Rosaceae & 17 \\
\hline V38 & Dry perennial anthropogenic herbaceous vegetation & Rubiaceae & 21 \\
\hline V38 & Dry perennial anthropogenic herbaceous vegetation & Urticaceae & 20 \\
\hline V39 & Mesic perennial anthropogenic herbaceous vegetation & Adoxaceae & 9 \\
\hline V39 & Mesic perennial anthropogenic herbaceous vegetation & Apiaceae & 96 \\
\hline V39 & Mesic perennial anthropogenic herbaceous vegetation & Balsaminaceae & 9 \\
\hline V39 & Mesic perennial anthropogenic herbaceous vegetation & Brassicaceae & 24 \\
\hline V39 & Mesic perennial anthropogenic herbaceous vegetation & Cannabaceae & 5 \\
\hline V39 & Mesic perennial anthropogenic herbaceous vegetation & Caryophyllaceae & 20 \\
\hline
\end{tabular}




\begin{tabular}{|c|c|c|c|}
\hline EUNIS & EUNISName & Family & SUM \\
\hline V39 & Mesic perennial anthropogenic herbaceous vegetation & Compositae & 143 \\
\hline V39 & Mesic perennial anthropogenic herbaceous vegetation & Convolvulaceae & 30 \\
\hline V39 & Mesic perennial anthropogenic herbaceous vegetation & Equisetaceae & 5 \\
\hline V39 & Mesic perennial anthropogenic herbaceous vegetation & Fabaceae & 6 \\
\hline V39 & Mesic perennial anthropogenic herbaceous vegetation & Lamiaceae & 61 \\
\hline V39 & Mesic perennial anthropogenic herbaceous vegetation & Papaveraceae & 20 \\
\hline V39 & Mesic perennial anthropogenic herbaceous vegetation & Plantaginaceae & 17 \\
\hline V39 & Mesic perennial anthropogenic herbaceous vegetation & Poaceae & 136 \\
\hline V39 & Mesic perennial anthropogenic herbaceous vegetation & Rubiaceae & 58 \\
\hline V39 & Mesic perennial anthropogenic herbaceous vegetation & Urticaceae & 70 \\
\hline
\end{tabular}




\section{Annex 4 List of 329 plant species of the eight EUNIS habitats}

\begin{tabular}{|c|c|c|}
\hline Speciesname & Family & Group \\
\hline Achillea millefolium & Compositae & Dicotyls \\
\hline Adonis aestivalis & Ranunculaceae & Dicotyls \\
\hline Aegopodium podagraria & Apiaceae & Dicotyls \\
\hline Agrostemma githago & Caryophyllaceae & Dicotyls \\
\hline Agrostis capillaris & Poaceae & Monocotyls \\
\hline Agrostis gigantea & Poaceae & Monocotyls \\
\hline Alliaria petiolata & Brassicaceae & Dicotyls \\
\hline Amaranthus albus & Amaranthaceae & Dicotyls \\
\hline Amaranthus blitoides & Amaranthaceae & Dicotyls \\
\hline Amaranthus deflexus & Amaranthaceae & Dicotyls \\
\hline Amaranthus hybridus & Amaranthaceae & Dicotyls \\
\hline Amaranthus retroflexus & Amaranthaceae & Dicotyls \\
\hline Anagallis arvensis & Primulaceae & Dicotyls \\
\hline Anagallis foemina & Primulaceae & Dicotyls \\
\hline Anchusa arvensis & Boraginaceae & Dicotyls \\
\hline Anethum graveolens & Apiaceae & Dicotyls \\
\hline Anisantha sterilis & Poaceae & Monocotyls \\
\hline Anthemis arvensis & Compositae & Dicotyls \\
\hline Anthemis austriaca & Compositae & Dicotyls \\
\hline Anthoxanthum aristatum & Poaceae & Monocotyls \\
\hline Anthoxanthum odoratum & Poaceae & Monocotyls \\
\hline Anthriscus sylvestris & Apiaceae & Dicotyls \\
\hline Apera spica-venti & Poaceae & Monocotyls \\
\hline Aphanes arvensis & Rosaceae & Dicotyls \\
\hline Arabidopsis thaliana & Brassicaceae & Dicotyls \\
\hline Arctium lappa & Compositae & Dicotyls \\
\hline Arctium minus & Compositae & Dicotyls \\
\hline Arctium tomentosum & Compositae & Dicotyls \\
\hline Arenaria serpyllifolia & Caryophyllaceae & Dicotyls \\
\hline Argentina anserina & Rosaceae & Dicotyls \\
\hline Armoracia rusticana & Brassicaceae & Dicotyls \\
\hline Arnoseris minima & Compositae & Dicotyls \\
\hline Arrhenatherum elatius & Poaceae & Monocotyls \\
\hline Artemisia absinthium & Compositae & Dicotyls \\
\hline Artemisia campestris & Compositae & Dicotyls \\
\hline Artemisia vulgaris & Compositae & Dicotyls \\
\hline Atriplex nitens & Amaranthaceae & Dicotyls \\
\hline Atriplex patula & Amaranthaceae & Dicotyls \\
\hline Atriplex tatarica & Amaranthaceae & Dicotyls \\
\hline Avena fatua & Poaceae & Monocotyls \\
\hline Avena sativa & Poaceae & Monocotyls \\
\hline Ballota nigra & Lamiaceae & Dicotyls \\
\hline Berteroa incana & Brassicaceae & Dicotyls \\
\hline Beta vulgaris & Brassicaceae & Dicotyls \\
\hline Beta vulgaris subsp. vulgaris & Chenopodiaceae & Dicotyls \\
\hline Bidens tripartita & Compositae & Dicotyls \\
\hline Bifora testiculata & Apiaceae & Dicotyls \\
\hline Brassica napus & Brassicaceae & Dicotyls \\
\hline Brassica oleracea & Brassicaceae & Dicotyls \\
\hline Brassica rapa & Brassicaceae & Dicotyls \\
\hline Bromus hordeaceus & Poaceae & Monocotyls \\
\hline Bromus hordeaceus subsp. hordeaceus & Poaceae & Monocotyls \\
\hline
\end{tabular}




\begin{tabular}{|c|c|c|}
\hline Speciesname & Family & Group \\
\hline Bromus inermis & Poaceae & Monocotyls \\
\hline Bromus secalinus & Poaceae & Monocotyls \\
\hline Bromus sterilis & Poaceae & Monocotyls \\
\hline Bromus tectorum & Poaceae & Monocotyls \\
\hline Bryum argenteum & Bryophyta & Bryophyta \\
\hline Buglossoides arvensis & Boraginaceae & Dicotyls \\
\hline Calamagrostis epigejos & Poaceae & Monocotyls \\
\hline Calystegia sepium & Convolvulaceae & Dicotyls \\
\hline Camelina microcarpa & Brassicaceae & Dicotyls \\
\hline Campanula rapunculoides & Campanulaceae & Dicotyls \\
\hline Capsella bursa-pastoris & Brassicaceae & Dicotyls \\
\hline Cardaria draba & Brassicaceae & Dicotyls \\
\hline Carduus acanthoides & Compositae & Dicotyls \\
\hline Carduus crispus & Compositae & Dicotyls \\
\hline Carex praecox & Cyperaceae & Monocotyls \\
\hline Caucalis platycarpos & Apiaceae & Dicotyls \\
\hline Centaurea cyanus & Compositae & Dicotyls \\
\hline Cerastium fontanum subsp. vulgare & Caryophyllaceae & Dicotyls \\
\hline Cerastium glomeratum & Caryophyllaceae & Dicotyls \\
\hline \multicolumn{3}{|l|}{ Ceratodon purpureus } \\
\hline Chaerophyllum aureum & Apiaceae & Dicotyls \\
\hline Chaerophyllum bulbosum & Apiaceae & Dicotyls \\
\hline Chaerophyllum temulum & Apiaceae & Dicotyls \\
\hline Chamomilla recutita & Compositae & Dicotyls \\
\hline Chamomilla suaveolens & Compositae & Dicotyls \\
\hline Chelidonium majus & Papaveraceae & Dicotyls \\
\hline Chenopodium album & Chenopodiaceae & Dicotyls \\
\hline Chenopodium album aggr. & Chenopodiaceae & Dicotyls \\
\hline Chenopodium hybridum & Chenopodiaceae & Dicotyls \\
\hline Chenopodium polyspermum & Chenopodiaceae & Dicotyls \\
\hline Chondrilla juncea & Compositae & Dicotyls \\
\hline Cichorium intybus & Compositae & Dicotyls \\
\hline Cirsium arvense & Compositae & Dicotyls \\
\hline Cirsium vulgare & Compositae & Dicotyls \\
\hline Conium maculatum & Apiaceae & Dicotyls \\
\hline Consolida regalis & Ranunculaceae & Dicotyls \\
\hline Convolvulus arvensis & Convolvulaceae & Dicotyls \\
\hline Conyza bonariensis & Compositae & Dicotyls \\
\hline Conyza canadensis & Compositae & Dicotyls \\
\hline Conyzanthus squamatus & Compositae & Dicotyls \\
\hline Coronopus squamatus & Brassicaceae & Dicotyls \\
\hline Cota austriaca & Compositae & Dicotyls \\
\hline Cruciata laevipes & Rubiaceae & Dicotyls \\
\hline Cucumis sativus & Cucurbitaceaea & Dicotyls \\
\hline Cucurbita pepo & Cucurbitaceae & Dicotyls \\
\hline Cyanus segetum & Compositae & Dicotyls \\
\hline Cynodon dactylon & Poaceae & Monocotyls \\
\hline Dactylis glomerata & Poaceae & Monocotyls \\
\hline Datura stramonium & Solanaceae & Dicotyls \\
\hline Daucus carota & Apiaceae & Dicotyls \\
\hline Descurainia sophia & Brassicaceae & Dicotyls \\
\hline Digitaria sanguinalis & Poaceae & Monocotyls \\
\hline Echinochloa crus-galli & Paniceae & Monocotyls \\
\hline Echium vulgare & Boraginaceae & Dicotyls \\
\hline Eleusine indica & Poaceae & Monocotyls \\
\hline Elsholtzia ciliata & Lamiaceae & Dicotyls \\
\hline Elymus repens & Poaceae & Monocotyls \\
\hline Elytrigia repens & Poaceae & Monocotyls \\
\hline
\end{tabular}




\begin{tabular}{|c|c|c|}
\hline Speciesname & Family & Group \\
\hline Equisetum arvense & Equisetaceae & Dicotyls \\
\hline Eragrostis cilianensis & Poaceae & Monocotyls \\
\hline Eragrostis minor & Poaceae & Monocotyls \\
\hline Eragrostis pilosa & Poaceae & Monocotyls \\
\hline Erigeron annuus & Compositae & Dicotyls \\
\hline Erigeron canadensis & Compositae & Dicotyls \\
\hline Erodium cicutarium & Geraniaceae & Dicotyls \\
\hline Erophila verna & Brassicaceae & Dicotyls \\
\hline Eryngium campestre & Apiaceae & Dicotyls \\
\hline Erysimum cheiranthoides & Brassicaceae & Dicotyls \\
\hline Euphorbia cyparissias & Euphorbiaceae & Dicotyls \\
\hline Euphorbia esula subsp. tommasiniana & Euphorbiaceae & Dicotyls \\
\hline Euphorbia exigua & Euphorbiaceae & Dicotyls \\
\hline Euphorbia helioscopia & Euphorbiaceae & Dicotyls \\
\hline Euphorbia maculata & Euphorbiaceae & Dicotyls \\
\hline Euphorbia peplus & Euphorbiaceae & Dicotyls \\
\hline Falcaria vulgaris & Apiaceae & Dicotyls \\
\hline Fallopia convolvulus & Polygonaceae & Dicotyls \\
\hline Festuca pratensis & Poaceae & Monocotyls \\
\hline Festuca rubra & Poaceae & Monocotyls \\
\hline Fumaria officinalis & Papaveraceae & Dicotyls \\
\hline Galeopsis bifida & Apiaceae & Dicotyls \\
\hline Galeopsis tetrahit & Apiaceae & Dicotyls \\
\hline Galinsoga ciliata & Compositae & Dicotyls \\
\hline Galinsoga parviflora & Compositae & Dicotyls \\
\hline Galinsoga quadriradiata & Compositae & Dicotyls \\
\hline Galium album & Rubiaceae & Dicotyls \\
\hline Galium aparine & Rubiaceae & Dicotyls \\
\hline Galium mollugo & Rubiaceae & Dicotyls \\
\hline Galium spurium & Rubiaceae & Dicotyls \\
\hline Galium tricornutum & Rubiaceae & Dicotyls \\
\hline Galium verum & Rubiaceae & Dicotyls \\
\hline Geranium dissectum & Geraniaceae & Dicotyls \\
\hline Geranium pusillum & Geraniaceae & Dicotyls \\
\hline Geranium robertianum & Geraniaceae & Dicotyls \\
\hline Geum urbanum & Rosaceae & Dicotyls \\
\hline Glechoma hederacea & Lamiaceae & Dicotyls \\
\hline Gnaphalium uliginosum & Compositae & Dicotyls \\
\hline Gypsophila muralis & Caryophyllaceae & Dicotyls \\
\hline Helianthus annuus & Compositae & Dicotyls \\
\hline Helianthus tuberosus & Compositae & Dicotyls \\
\hline Heliotropium europaeum & Brassicaceae & Dicotyls \\
\hline Heracleum sphondylium & Apiaceae & Dicotyls \\
\hline Holcus lanatus & Poaceae & Monocotyls \\
\hline Holcus mollis & Poaceae & Monocotyls \\
\hline Hordeum distichon & Poaceae & Monocotyls \\
\hline Hordeum murinum & Poaceae & Monocotyls \\
\hline Hordeum murinum subsp. leporinum & Poaceae & Monocotyls \\
\hline Hordeum vulgare & Poaceae & Monocotyls \\
\hline Humulus lupulus & Cannabaceae & Dicotyls \\
\hline Hypericum perforatum & Hypericacaea & Dicotyls \\
\hline Impatiens parviflora & Balsaminaceae & Dicotyls \\
\hline Inula britannica & Compositae & Dicotyls \\
\hline Juncus bufonius & Juncaceae & Monocotyls \\
\hline Lactuca sativa & Compositae & Dicotyls \\
\hline Lactuca serriola & Compositae & Dicotyls \\
\hline Lamium album & Lamiaceae & Dicotyls \\
\hline Lamium amplexicaule & Lamiaceae & Dicotyls \\
\hline
\end{tabular}




\begin{tabular}{|c|c|c|}
\hline Speciesname & Family & Group \\
\hline Lamium maculatum & Lamiaceae & Dicotyls \\
\hline Lamium purpureum & Lamiaceae & Dicotyls \\
\hline Lapsana communis & Compositae & Dicotyls \\
\hline Lathyrus pratensis & Fabaceae & Dicotyls \\
\hline Lathyrus tuberosus & Fabaceae & Dicotyls \\
\hline Legousia speculum-veneris & Campanulaceae & Dicotyls \\
\hline Leontodon autumnalis & Compositae & Dicotyls \\
\hline Lepidium ruderale & Brassicaceae & Dicotyls \\
\hline Leucanthemum vulgare & Compositae & Dicotyls \\
\hline Linaria vulgaris & Plantaginaceae & Dicotyls \\
\hline Linum usitatissimum & Linaceae & Dicotyls \\
\hline Lipandra polysperma & Chenopodiaceae & Dicotyls \\
\hline Lolium perenne & Poaceae & Monocotyls \\
\hline Lolium rigidum & Poaceae & Monocotyls \\
\hline Lotus corniculatus & Fabaceae & Dicotyls \\
\hline Lycopersicon esculentum & Solanaceae & Dicotyls \\
\hline Malva neglecta & Malvaceae & Dicotyls \\
\hline Malva sylvestris & Malvaceae & Dicotyls \\
\hline Matricaria perforata & Compositae & Dicotyls \\
\hline Medicago lupulina & Fabaceae & Dicotyls \\
\hline Medicago sativa & Fabaceae & Dicotyls \\
\hline Medicago sativa subsp. falcata & Fabaceae & Dicotyls \\
\hline Melilotus alba & Fabaceae & Dicotyls \\
\hline Melilotus officinalis & Fabaceae & Dicotyls \\
\hline Mentha arvensis & Lamiaceae & Dicotyls \\
\hline Myosotis arvensis & Boraginaceae & Dicotyls \\
\hline Myosotis stricta & Boraginaceae & Dicotyls \\
\hline Neslia paniculata & Brassicaceae & Dicotyls \\
\hline Ochlopoa annua & Poaceae & Monocotyls \\
\hline Oenothera biennis & Onagraceae & Dicotyls \\
\hline Onopordum acanthium & Compositae & Dicotyls \\
\hline Oxalis corniculata & Euphorbiaceae & Dicotyls \\
\hline Oxalis stricta & Oxalidaceae & Dicotyls \\
\hline Papaver argemone & Papaveraceae & Dicotyls \\
\hline Papaver dubium & Papaveraceae & Dicotyls \\
\hline Papaver rhoeas & Papaveraceae & Dicotyls \\
\hline Papaver somniferum & Papaveraceae & Dicotyls \\
\hline Pastinaca sativa & Anacardiaceaea & Dicotyls \\
\hline Persicaria lapathifolia & Polygonaceae & Dicotyls \\
\hline Persicaria maculosa & Polygonaceae & Dicotyls \\
\hline Phalaris arundinacea & Poaceae & Monocotyls \\
\hline Phleum pratense & Poaceae & Monocotyls \\
\hline Phragmites australis & Poaceae & Monocotyls \\
\hline Picris hieracioides & Compositae & Dicotyls \\
\hline Pisum sativum & Fabaceae & Dicotyls \\
\hline Plantago coronopus & Plantaginaceae & Dicotyls \\
\hline Plantago lanceolata & Plantaginaceae & Dicotyls \\
\hline Plantago major & Plantaginaceae & Dicotyls \\
\hline Plantago major subsp. intermedia & Plantaginaceae & Dicotyls \\
\hline Plantago major subsp. major & Plantaginaceae & Dicotyls \\
\hline Poa angustifolia & Poaceae & Monocotyls \\
\hline Poa annua & Poaceae & Monocotyls \\
\hline Poa bulbosa & Poaceae & Monocotyls \\
\hline Poa compressa & Poaceae & Monocotyls \\
\hline Poa pratensis & Poaceae & Monocotyls \\
\hline Poa trivialis & Poaceae & Monocotyls \\
\hline Polycarpon tetraphyllum & Caryophyllaceae & Dicotyls \\
\hline Polygonum arenastrum & Polygonaceae & Dicotyls \\
\hline
\end{tabular}




\begin{tabular}{|c|c|c|}
\hline Speciesname & Family & Group \\
\hline Polygonum aviculare & Polygonaceae & Dicotyls \\
\hline Polygonum aviculare aggr. & Polygonaceae & Dicotyls \\
\hline Polygonum hydropiper & Polygonaceae & Dicotyls \\
\hline Polygonum lapathifolium & Polygonaceae & Dicotyls \\
\hline Polygonum persicaria & Polygonaceae & Dicotyls \\
\hline Polygonum tomentosum & Polygonaceae & Dicotyls \\
\hline Portulaca oleracea & Portulacaceae & Dicotyls \\
\hline Potentilla anserina & Rosaceae & Dicotyls \\
\hline Potentilla argentea & Rosaceae & Dicotyls \\
\hline Potentilla reptans & Rosaceae & Dicotyls \\
\hline Prunella vulgaris & Lamiaceae & Dicotyls \\
\hline Ranunculus arvensis & Ranunculaceae & Dicotyls \\
\hline Ranunculus bulbosus & Ranunculaceae & Dicotyls \\
\hline Ranunculus repens & Ranunculaceae & Dicotyls \\
\hline Raphanus raphanistrum & Brassicaceae & Dicotyls \\
\hline Raphanus sativus & Brassicaceae & Dicotyls \\
\hline Reseda lutea & Resedaceaea & Dicotyls \\
\hline Reynoutria japonica & Polygonaceae & Dicotyls \\
\hline Rorippa sylvestris & Brassicaceae & Dicotyls \\
\hline Rostraria cristata & Poaceae & Monocotyls \\
\hline Rubus caesius & Rosaceae & Dicotyls \\
\hline Rumex acetosa & Polygonaceae & Dicotyls \\
\hline Rumex acetosella & Polygonaceae & Dicotyls \\
\hline Rumex crispus & Polygonaceae & Dicotyls \\
\hline Rumex obtusifolius & Polygonaceae & Dicotyls \\
\hline Sagina apetala & Caryophyllaceae & Dicotyls \\
\hline Sagina procumbens & Caryophyllaceae & Dicotyls \\
\hline Sambucus nigra & Adoxaceae & Dicotyls \\
\hline Sanguisorba minor & Rosaceae & Dicotyls \\
\hline Scandix pecten-veneris & Apiaceae & Dicotyls \\
\hline Scleranthus annuus & Caryophyllaceae & Dicotyls \\
\hline Sclerochloa dura & Poaceae & Monocotyls \\
\hline Secale cereale & Triticeae & Dicotyls \\
\hline Senecio jacobaea & Compositae & Dicotyls \\
\hline Senecio vulgaris & Compositae & Dicotyls \\
\hline Setaria pumila & Poaceae & Monocotyls \\
\hline Setaria verticillata & Poaceae & Monocotyls \\
\hline Setaria viridis & Poaceae & Monocotyls \\
\hline Sherardia arvensis & Rubiaceae & Dicotyls \\
\hline Silene latifolia & Caryophyllaceae & Dicotyls \\
\hline Silene latifolia subsp. alba & Caryophyllaceae & Dicotyls \\
\hline Silene noctiflora & Caryophyllaceae & Dicotyls \\
\hline Silene vulgaris & Caryophyllaceae & Dicotyls \\
\hline Sinapis arvensis & Brassicaceae & Dicotyls \\
\hline Sisymbrium loeselii & Brassicaceae & Dicotyls \\
\hline Sisymbrium officinale & Brassicaceae & Dicotyls \\
\hline Solanum nigrum & Solanaceae & Dicotyls \\
\hline Solanum tuberosum & Solanaceae & Dicotyls \\
\hline Solidago canadensis & Compositae & Dicotyls \\
\hline Solidago gigantea & Compositae & Dicotyls \\
\hline Sonchus arvensis & Compositae & Dicotyls \\
\hline Sonchus asper & Compositae & Dicotyls \\
\hline Sonchus oleraceus & Compositae & Dicotyls \\
\hline Sorghum halepense & Poaceae & Monocotyls \\
\hline Spergula arvensis & Caryophyllaceae & Dicotyls \\
\hline Spergularia rubra & Caryophyllaceae & Dicotyls \\
\hline Stachys annua & Lamiaceae & Dicotyls \\
\hline Stachys palustris & Lamiaceae & Dicotyls \\
\hline
\end{tabular}




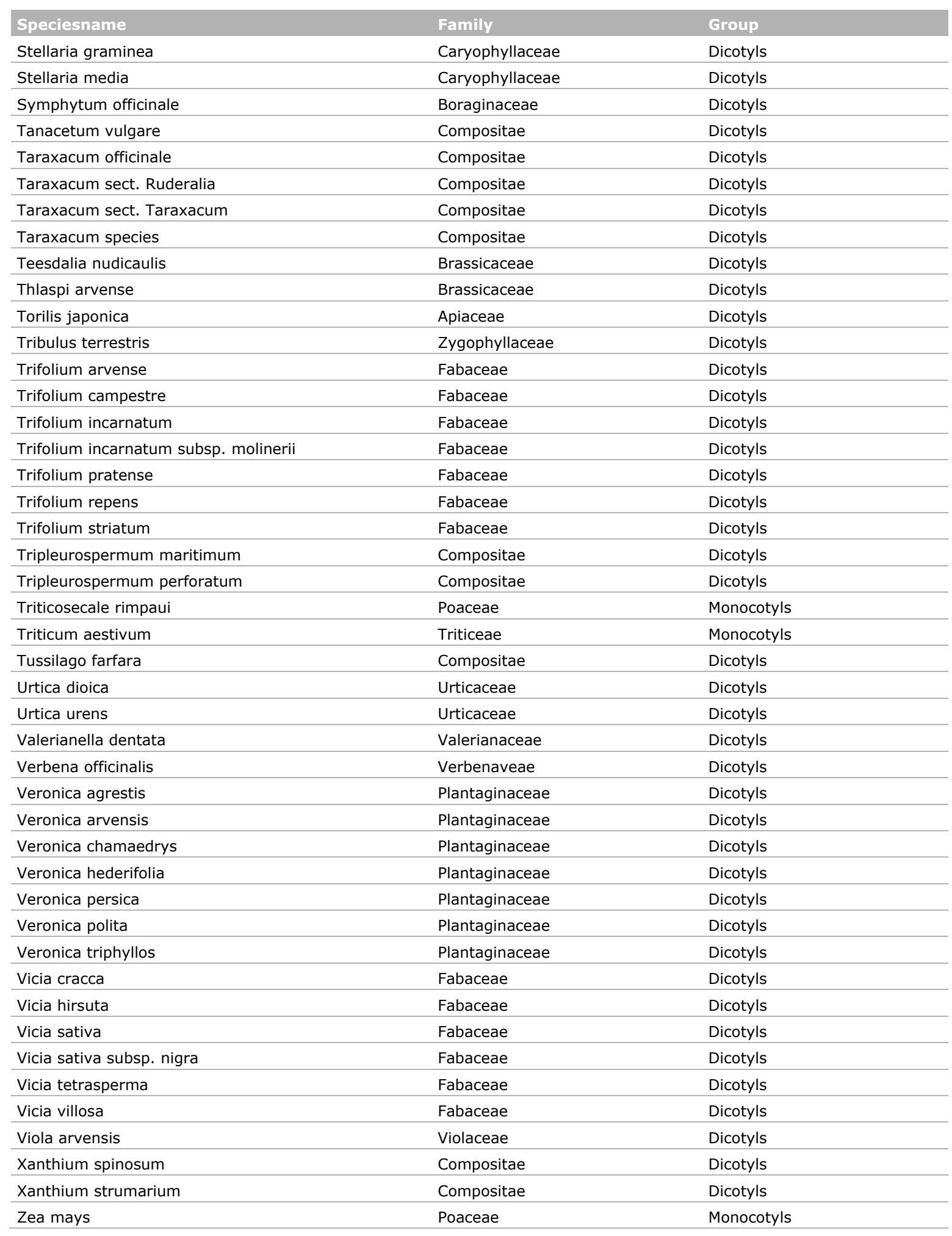




\section{Annex 5 Species list per EUNIS habitat}

$\checkmark$ numbers refer to man-made habitats. Frequency in percentages. Mip $=$ mean abundance if present

V11

\begin{tabular}{|c|c|c|}
\hline Species name & Frequency & Mip \\
\hline Chenopodium album & 32 & 5 \\
\hline Elymus repens & 32 & 6 \\
\hline Cirsium arvense & 29 & 3 \\
\hline Convolvulus arvensis & 29 & 3 \\
\hline Fallopia convolvulus & 25 & 3 \\
\hline Viola arvensis & 23 & 3 \\
\hline Plantago lanceolata & 19 & 3 \\
\hline Achillea millefolium & 18 & 3 \\
\hline Veronica persica & 14 & 4 \\
\hline Echinochloa crus-galli & 14 & 5 \\
\hline Myosotis arvensis & 13 & 4 \\
\hline Dactylis glomerata & 13 & 7 \\
\hline Trifolium repens & 13 & 4 \\
\hline Tripleurospermum perforatum & 13 & 5 \\
\hline Sonchus arvensis & 13 & 4 \\
\hline Veronica arvensis & 13 & 3 \\
\hline Lolium perenne & 12 & 5 \\
\hline Polygonum lapathifolium & 11 & 5 \\
\hline Anagallis arvensis & 11 & 2 \\
\hline Thlaspi arvense & 11 & 2 \\
\hline Euphorbia helioscopia & 11 & 2 \\
\hline Sonchus oleraceus & 11 & 3 \\
\hline Lamium purpureum & 11 & 4 \\
\hline Amaranthus retroflexus & 11 & 6 \\
\hline Erodium cicutarium & 11 & 3 \\
\hline Rumex acetosella & 11 & 4 \\
\hline Centaurea cyanus & 10 & 4 \\
\hline Vicia hirsuta & 9 & 3 \\
\hline Medicago lupulina & 9 & 3 \\
\hline Taraxacum sect. Ruderalia & 9 & 5 \\
\hline Plantago major & 9 & 2 \\
\hline Sinapis arvensis & 9 & 5 \\
\hline Setaria pumila & 9 & 5 \\
\hline Raphanus raphanistrum & 9 & 6 \\
\hline Polygonum persicaria & 9 & 3 \\
\hline
\end{tabular}




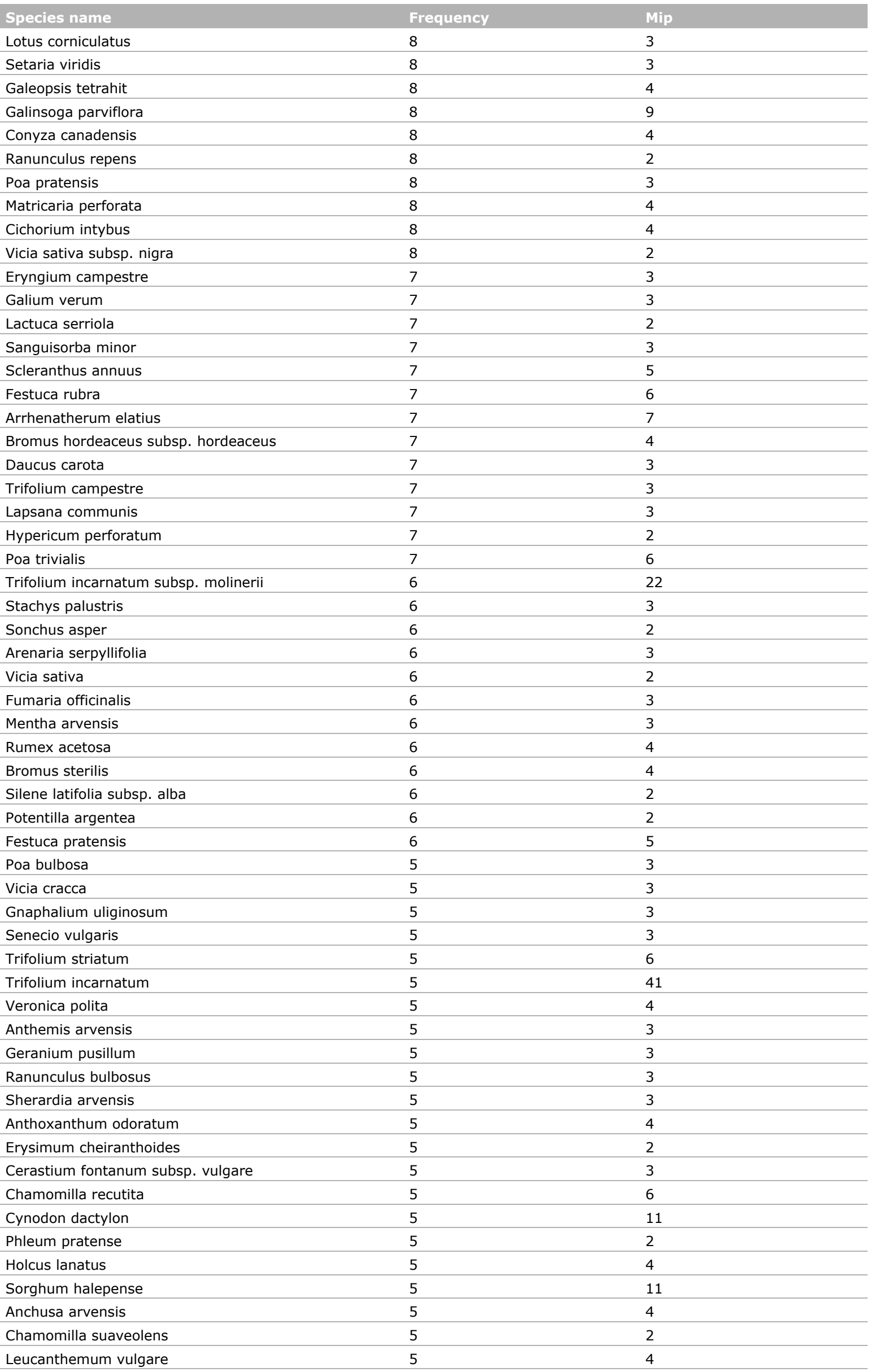


V12

\begin{tabular}{|c|c|c|}
\hline Species name & Frequency & Mip \\
\hline Stellaria media & 53 & 8 \\
\hline Chenopodium album & 49 & 4 \\
\hline Daucus carota & 45 & 4 \\
\hline Convolvulus arvensis & 43 & 5 \\
\hline Fallopia convolvulus & 41 & 5 \\
\hline Cirsium arvense & 40 & 2 \\
\hline Capsella bursa-pastoris & 39 & 2 \\
\hline Veronica persica & 37 & 3 \\
\hline Polygonum persicaria & 35 & 3 \\
\hline Elymus repens & 35 & 3 \\
\hline Galeopsis tetrahit & 34 & 6 \\
\hline Viola arvensis & 34 & 3 \\
\hline Poa annua & 31 & 5 \\
\hline Sonchus oleraceus & 29 & 2 \\
\hline Trifolium repens & 29 & 2 \\
\hline Lamium purpureum & 27 & 2 \\
\hline Ranunculus repens & 27 & 3 \\
\hline Equisetum arvense & 26 & 3 \\
\hline Galinsoga parviflora & 26 & 16 \\
\hline Euphorbia helioscopia & 26 & 2 \\
\hline Solanum tuberosum & 26 & 2 \\
\hline Achillea millefolium & 25 & 2 \\
\hline Myosotis arvensis & 25 & 3 \\
\hline Sonchus arvensis & 24 & 5 \\
\hline Mentha arvensis & 24 & 6 \\
\hline Anagallis arvensis & 23 & 2 \\
\hline Echinochloa crus-galli & 23 & 6 \\
\hline Sonchus asper & 22 & 2 \\
\hline Polygonum aviculare & 21 & 4 \\
\hline Polygonum lapathifolium & 21 & 3 \\
\hline Plantago lanceolata & 21 & 2 \\
\hline Vicia hirsuta & 20 & 3 \\
\hline Rumex crispus & 20 & 2 \\
\hline Galium aparine & 20 & 5 \\
\hline Taraxacum officinale & 20 & 2 \\
\hline Lapsana communis & 19 & 3 \\
\hline Atriplex patula & 19 & 3 \\
\hline Plantago major & 19 & 2 \\
\hline Artemisia vulgaris & 18 & 3 \\
\hline Medicago lupulina & 18 & 2 \\
\hline Matricaria perforata & 18 & 4 \\
\hline Sinapis arvensis & 18 & 2 \\
\hline Galinsoga ciliata & 17 & 9 \\
\hline Potentilla anserina & 17 & 3 \\
\hline Polygonum aviculare aggr. & 17 & 3 \\
\hline Tussilago farfara & 16 & 2 \\
\hline Pisum sativum & 16 & 10 \\
\hline Geranium pusillum & 16 & 2 \\
\hline Plantago major subsp. intermedia & 16 & 3 \\
\hline Amaranthus retroflexus & 15 & 3 \\
\hline Armoracia rusticana & 15 & 4 \\
\hline Brassica rapa & 15 & 19 \\
\hline Setaria pumila & 15 & 5 \\
\hline Chenopodium album aggr. & 15 & 4 \\
\hline Taraxacum sect. Ruderalia & 15 & 3 \\
\hline Avena sativa & 14 & 41 \\
\hline Silene latifolia subsp. alba & 14 & 2 \\
\hline
\end{tabular}




\begin{tabular}{|c|c|c|}
\hline Species name & Frequency & Mip \\
\hline Trifolium pratense & 13 & 4 \\
\hline Stachys palustris & 13 & 9 \\
\hline Papaver rhoeas & 13 & 2 \\
\hline Setaria viridis & 13 & 2 \\
\hline Anthemis arvensis & 13 & 6 \\
\hline Vicia sativa & 13 & 3 \\
\hline Erodium cicutarium & 13 & 2 \\
\hline Veronica arvensis & 13 & 2 \\
\hline Erysimum cheiranthoides & 12 & 3 \\
\hline Chenopodium polyspermum & 12 & 5 \\
\hline Vicia sativa subsp. nigra & 12 & 2 \\
\hline Rumex obtusifolius & 12 & 2 \\
\hline Polygonum tomentosum & 12 & 3 \\
\hline Centaurea cyanus & 11 & 2 \\
\hline Thlaspi arvense & 11 & 2 \\
\hline Spergula arvensis & 11 & 3 \\
\hline Veronica polita & 11 & 2 \\
\hline Lycopersicon esculentum & 11 & 24 \\
\hline Avena fatua & 11 & 2 \\
\hline Secale cereale & 11 & 64 \\
\hline Urtica dioica & 10 & 2 \\
\hline Dactylis glomerata & 10 & 2 \\
\hline Senecio vulgaris & 9 & 2 \\
\hline Raphanus raphanistrum & 9 & 2 \\
\hline Polygonum hydropiper & 9 & 4 \\
\hline Urtica urens & 9 & 4 \\
\hline Tripleurospermum perforatum & 9 & 3 \\
\hline Conyza canadensis & 8 & 2 \\
\hline Chamomilla suaveolens & 8 & 2 \\
\hline Vicia cracca & 8 & 2 \\
\hline Papaver somniferum & 8 & 2 \\
\hline Oxalis stricta & 8 & 2 \\
\hline Rumex acetosella & 8 & 4 \\
\hline Potentilla reptans & 8 & 2 \\
\hline Anethum graveolens & 8 & 2 \\
\hline Gnaphalium uliginosum & 8 & 3 \\
\hline Helianthus annuus & 8 & 3 \\
\hline Brassica oleracea & 8 & 2 \\
\hline Scleranthus annuus & 8 & 14 \\
\hline Stellaria graminea & 8 & 2 \\
\hline Lamium amplexicaule & 8 & 2 \\
\hline Portulaca oleracea & 8 & 16 \\
\hline Galium spurium & 8 & 2 \\
\hline Sherardia arvensis & 8 & 10 \\
\hline Digitaria sanguinalis & 8 & 4 \\
\hline Agrostis gigantea & 8 & 2 \\
\hline Apera spica-venti & 8 & 4 \\
\hline Poa trivialis & 8 & 2 \\
\hline Hordeum distichon & 8 & 52 \\
\hline Anchusa arvensis & 7 & 10 \\
\hline Arabidopsis thaliana & 7 & 2 \\
\hline Arenaria serpyllifolia & 7 & 2 \\
\hline Euphorbia peplus & 7 & 3 \\
\hline Galeopsis bifida & 7 & 4 \\
\hline Fumaria officinalis & 7 & 2 \\
\hline Malva neglecta & 7 & 3 \\
\hline Linaria vulgaris & 7 & 2 \\
\hline Solanum nigrum & 7 & 12 \\
\hline
\end{tabular}




\begin{tabular}{|c|c|c|}
\hline Species name & Frequency & Mip \\
\hline Cerastium fontanum subsp. vulgare & 7 & 1 \\
\hline Lactuca sativa & 6 & 7 \\
\hline Cucurbita pepo & 6 & 20 \\
\hline Vicia villosa & 6 & 3 \\
\hline Prunella vulgaris & 6 & 2 \\
\hline Elsholtzia ciliata & 6 & 2 \\
\hline Setaria verticillata & 6 & 17 \\
\hline Cichorium intybus & 5 & 2 \\
\hline Echium vulgare & 5 & 2 \\
\hline Beta vulgaris & 5 & 2 \\
\hline Cucumis sativus & 5 & 66 \\
\hline Lathyrus pratensis & 5 & 4 \\
\hline Lotus corniculatus & 5 & 4 \\
\hline Geranium dissectum & 5 & 4 \\
\hline Reseda lutea & 5 & 2 \\
\hline
\end{tabular}

\section{V13}

\begin{tabular}{|c|c|c|}
\hline Species name & Frequency & Mip \\
\hline Centaurea cyanus & 66 & 5 \\
\hline Viola arvensis & 65 & 3 \\
\hline Fallopia convolvulus & 58 & 4 \\
\hline Convolvulus arvensis & 50 & 3 \\
\hline Cirsium arvense & 48 & 3 \\
\hline Secale cereale & 45 & 57 \\
\hline Stellaria media & 43 & 5 \\
\hline Apera spica-venti & 42 & 10 \\
\hline Scleranthus annuus & 42 & 6 \\
\hline Myosotis arvensis & 39 & 3 \\
\hline Anthemis arvensis & 38 & 4 \\
\hline Chenopodium album & 38 & 4 \\
\hline Elymus repens & 38 & 5 \\
\hline Capsella bursa-pastoris & 37 & 3 \\
\hline Equisetum arvense & 37 & 4 \\
\hline Vicia hirsuta & 36 & 4 \\
\hline Veronica arvensis & 34 & 3 \\
\hline Papaver rhoeas & 34 & 5 \\
\hline Raphanus raphanistrum & 33 & 3 \\
\hline Anagallis arvensis & 33 & 3 \\
\hline Vicia sativa subsp. nigra & 28 & 3 \\
\hline Rumex acetosella & 28 & 4 \\
\hline Achillea millefolium & 28 & 2 \\
\hline Galium aparine & 26 & 4 \\
\hline Polygonum aviculare & 26 & 3 \\
\hline Aphanes arvensis & 25 & 4 \\
\hline Spergula arvensis & 24 & 4 \\
\hline Buglossoides arvensis & 23 & 3 \\
\hline Triticum aestivum & 23 & 55 \\
\hline Arenaria serpyllifolia & 23 & 4 \\
\hline Matricaria perforata & 22 & 6 \\
\hline Veronica persica & 22 & 3 \\
\hline Arabidopsis thaliana & 20 & 4 \\
\hline Galeopsis tetrahit & 19 & 3 \\
\hline
\end{tabular}




\begin{tabular}{|c|c|c|}
\hline Species name & Frequency & Mip \\
\hline Sonchus arvensis & 19 & 4 \\
\hline Papaver argemone & 18 & 3 \\
\hline Sinapis arvensis & 18 & 4 \\
\hline Thlaspi arvense & 18 & 3 \\
\hline Lamium amplexicaule & 17 & 2 \\
\hline Vicia tetrasperma & 17 & 3 \\
\hline Agrostemma githago & 17 & 3 \\
\hline Euphorbia helioscopia & 16 & 2 \\
\hline Ranunculus repens & 16 & 3 \\
\hline Veronica hederifolia & 16 & 6 \\
\hline Polygonum aviculare aggr. & 16 & 3 \\
\hline Mentha arvensis & 16 & 4 \\
\hline Consolida regalis & 16 & 5 \\
\hline Polygonum persicaria & 14 & 3 \\
\hline Medicago lupulina & 14 & 3 \\
\hline Rumex crispus & 14 & 2 \\
\hline Vicia sativa & 14 & 3 \\
\hline Myosotis stricta & 13 & 4 \\
\hline Erodium cicutarium & 13 & 2 \\
\hline Artemisia vulgaris & 13 & 2 \\
\hline Arnoseris minima & 13 & 4 \\
\hline Lamium purpureum & 13 & 2 \\
\hline Veronica triphyllos & 13 & 5 \\
\hline Taraxacum officinale & 12 & 2 \\
\hline Stachys palustris & 12 & 3 \\
\hline Trifolium repens & 12 & 4 \\
\hline Ranunculus arvensis & 12 & 4 \\
\hline Vicia villosa & 12 & 5 \\
\hline Sherardia arvensis & 12 & 3 \\
\hline Lapsana communis & 12 & 3 \\
\hline Sonchus asper & 11 & 2 \\
\hline Cerastium fontanum subsp. vulgare & 11 & 2 \\
\hline Setaria pumila & 10 & 6 \\
\hline Agrostis gigantea & 10 & 5 \\
\hline Neslia paniculata & 10 & 2 \\
\hline Silene latifolia subsp. alba & 10 & 2 \\
\hline Lolium rigidum & 10 & 5 \\
\hline Valerianella dentata & 9 & 3 \\
\hline Juncus bufonius & 9 & 4 \\
\hline Gnaphalium uliginosum & 9 & 2 \\
\hline Galium tricornutum & 9 & 4 \\
\hline Erophila verna & 9 & 4 \\
\hline Daucus carota & 9 & 2 \\
\hline Euphorbia exigua & 9 & 3 \\
\hline Oxalis stricta & 9 & 3 \\
\hline Polygonum tomentosum & 8 & 3 \\
\hline Poa annua & 8 & 3 \\
\hline Polygonum lapathifolium & 8 & 3 \\
\hline Geranium pusillum & 8 & 2 \\
\hline Anchusa arvensis & 8 & 3 \\
\hline Plantago major & 8 & 2 \\
\hline Stellaria graminea & 8 & 3 \\
\hline Setaria viridis & 8 & 4 \\
\hline Geranium dissectum & 8 & 2 \\
\hline Silene noctiflora & 8 & 3 \\
\hline Fumaria officinalis & 8 & 2 \\
\hline Tripleurospermum perforatum & 8 & 6 \\
\hline Conyza canadensis & 7 & 2 \\
\hline
\end{tabular}




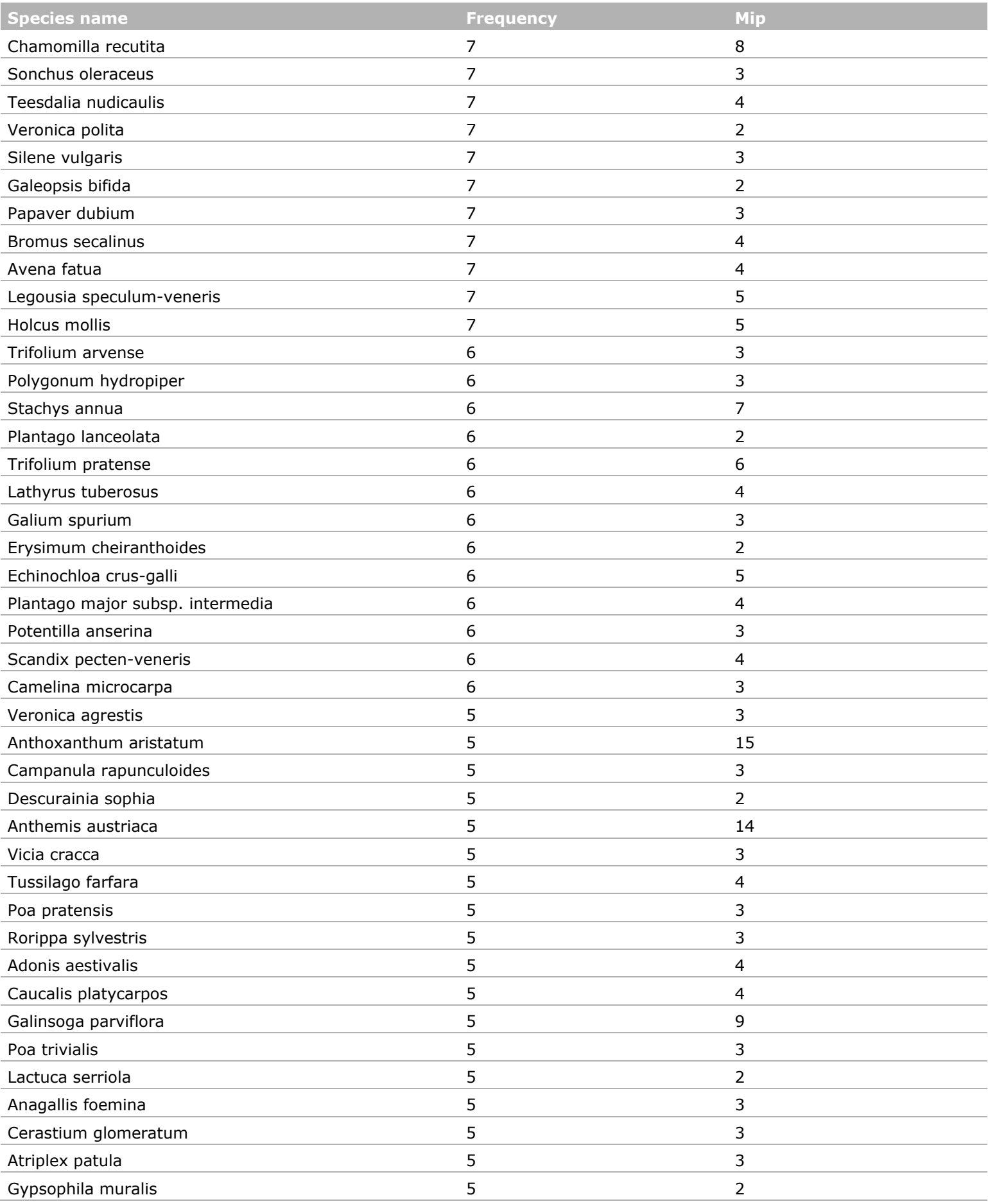

\section{V34}

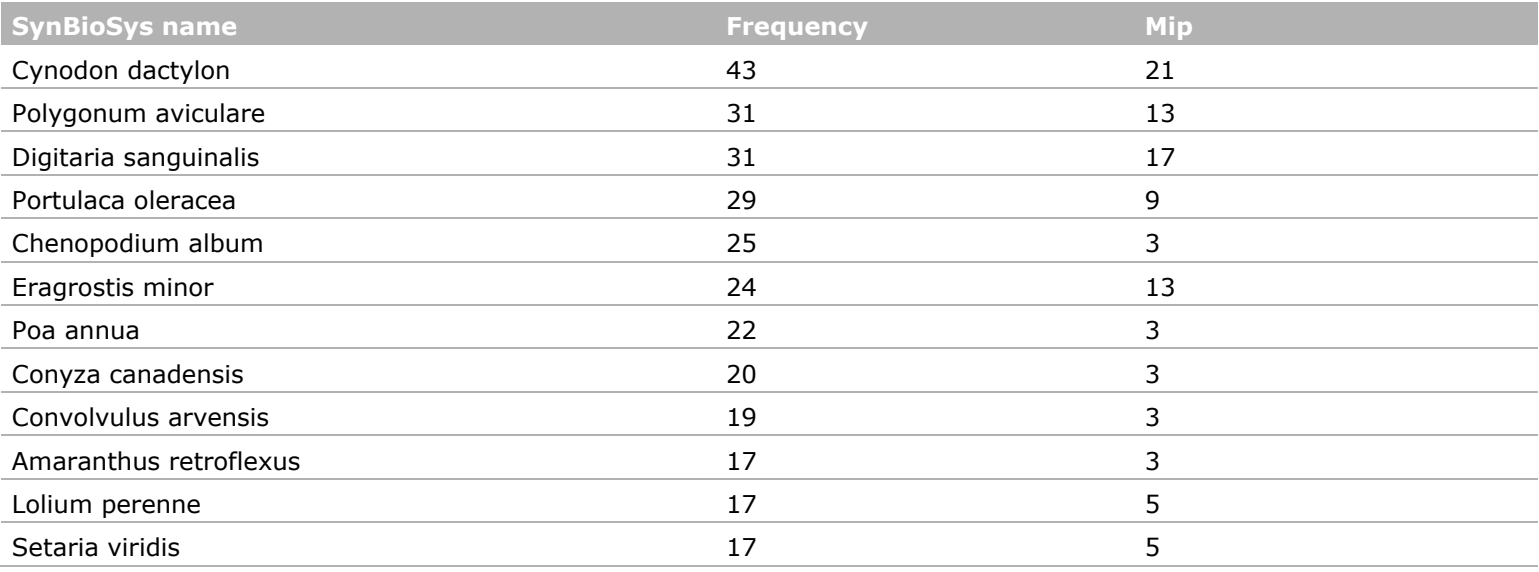




\begin{tabular}{|c|c|c|}
\hline SynBiosys name & Frequency & Mip \\
\hline Plantago major & 16 & 3 \\
\hline Polygonum arenastrum & 14 & 12 \\
\hline Plantago coronopus & 13 & 12 \\
\hline Plantago lanceolata & 13 & 3 \\
\hline Setaria pumila & 12 & 8 \\
\hline Echinochloa crus-galli & 12 & 5 \\
\hline Sclerochloa dura & 11 & 31 \\
\hline Sonchus oleraceus & 10 & 2 \\
\hline Taraxacum sect. Ruderalia & 8 & 2 \\
\hline Polycarpon tetraphyllum & 8 & 6 \\
\hline Conyza bonariensis & 8 & 6 \\
\hline Taraxacum officinale & 8 & 3 \\
\hline Medicago lupulina & 8 & 2 \\
\hline Trifolium repens & 8 & 2 \\
\hline Solanum nigrum & 7 & 3 \\
\hline Cichorium intybus & 7 & 2 \\
\hline Euphorbia maculata & 6 & 28 \\
\hline Hordeum murinum subsp. leporinum & 5 & 3 \\
\hline Conyzanthus squamatus & 5 & 3 \\
\hline Chamomilla recutita & 5 & 3 \\
\hline Amaranthus deflexus & 5 & 10 \\
\hline Eragrostis cilianensis & 5 & 7 \\
\hline Lepidium ruderale & 5 & 2 \\
\hline Eragrostis pilosa & 5 & 12 \\
\hline Lactuca serriola & 5 & 2 \\
\hline Sagina apetala & 5 & 5 \\
\hline
\end{tabular}

\section{V35}

\begin{tabular}{lll}
\hline SynBioSys name & Frequency & Mip \\
Poa annua & 83 & 18 \\
\hline Plantago major & 64 & 9 \\
\hline Chamomilla suaveolens & 47 & 11 \\
\hline Lolium perenne & 43 & 6 \\
\hline Polygonum aviculare & 41 & 23 \\
\hline Capsella bursa-pastoris & 36 & 3 \\
\hline Trifolium repens & 28 & 4 \\
\hline Polygonum arenastrum & 22 & 27 \\
\hline Taraxacum sect. Ruderalia & 22 & 3 \\
\hline Bryum argenteum & 18 & 13 \\
\hline Sagina procumbens & 16 & 12 \\
\hline Taraxacum officinale & 14 & 3 \\
\hline Polygonum aviculare aggr. & 14 & 22 \\
\hline Plantago lanceolata & 13 & 3 \\
\hline Lepidium ruderale & 12 & 11 \\
\hline Conyza canadensis & 12 & 3 \\
\hline Chenopodium album & 9 & 2 \\
\hline Stellaria media & 9 & 3
\end{tabular}




\begin{tabular}{|c|c|c|}
\hline SynBiosys name & Frequency & Mip \\
\hline Artemisia vulgaris & 9 & 2 \\
\hline Elymus repens & 8 & 3 \\
\hline Tripleurospermum perforatum & 8 & 2 \\
\hline Spergularia rubra & 8 & 11 \\
\hline Poa pratensis & 7 & 3 \\
\hline Coronopus squamatus & 7 & 16 \\
\hline Ceratodon purpureus & 7 & 10 \\
\hline Chamomilla recutita & 6 & 5 \\
\hline Potentilla anserina & 6 & 5 \\
\hline Leontodon autumnalis & 6 & 2 \\
\hline Sonchus oleraceus & 6 & 2 \\
\hline Plantago major subsp. major & 5 & 8 \\
\hline Agrostis capillaris & 5 & 4 \\
\hline Juncus bufonius & 5 & 6 \\
\hline Taraxacum species & 5 & 2 \\
\hline Malva neglecta & 5 & 4 \\
\hline
\end{tabular}

\section{V37}

\begin{tabular}{|c|c|c|}
\hline Species name & Frequency & Mip \\
\hline Chenopodium album & 48 & 11 \\
\hline Convolvulus arvensis & 37 & 6 \\
\hline Capsella bursa-pastoris & 30 & 4 \\
\hline Amaranthus retroflexus & 26 & 9 \\
\hline Cirsium arvense & 23 & 6 \\
\hline Polygonum aviculare & 22 & 5 \\
\hline Conyza canadensis & 22 & 5 \\
\hline Elymus repens & 21 & 5 \\
\hline Lactuca serriola & 20 & 7 \\
\hline Stellaria media & 19 & 8 \\
\hline Sonchus oleraceus & 18 & 3 \\
\hline Lolium perenne & 18 & 5 \\
\hline Poa annua & 18 & 5 \\
\hline Artemisia vulgaris & 17 & 4 \\
\hline Echinochloa crus-galli & 16 & 7 \\
\hline Bromus sterilis & 15 & 14 \\
\hline Solanum nigrum & 15 & 5 \\
\hline Sisymbrium officinale & 14 & 6 \\
\hline Hordeum murinum & 14 & 26 \\
\hline Plantago major & 13 & 3 \\
\hline Tripleurospermum perforatum & 13 & 6 \\
\hline Senecio vulgaris & 12 & 3 \\
\hline Urtica dioica & 12 & 5 \\
\hline Malva neglecta & 12 & 19 \\
\hline Cynodon dactylon & 11 & 7 \\
\hline Bromus tectorum & 11 & 12 \\
\hline Setaria viridis & 11 & 5 \\
\hline Atriplex patula & 11 & 8 \\
\hline Plantago lanceolata & 10 & 2 \\
\hline Setaria pumila & 10 & 7 \\
\hline Descurainia sophia & 10 & 8 \\
\hline Taraxacum sect. Ruderalia & 10 & 2 \\
\hline Taraxacum officinale & 10 & 2 \\
\hline
\end{tabular}




\begin{tabular}{|c|c|c|}
\hline Species name & Frequency & Mip \\
\hline Fallopia convolvulus & 9 & 3 \\
\hline Urtica urens & 9 & 10 \\
\hline Digitaria sanguinalis & 8 & 8 \\
\hline Portulaca oleracea & 8 & 7 \\
\hline Medicago lupulina & 8 & 2 \\
\hline Achillea millefolium & 8 & 3 \\
\hline Malva sylvestris & 8 & 7 \\
\hline Trifolium repens & 7 & 3 \\
\hline Geranium pusillum & 7 & 5 \\
\hline Daucus carota & 7 & 3 \\
\hline Atriplex tatarica & 7 & 24 \\
\hline Galinsoga parviflora & 7 & 4 \\
\hline Ballota nigra & 7 & 3 \\
\hline Sisymbrium loeselii & 7 & 13 \\
\hline Rumex crispus & 7 & 3 \\
\hline Equisetum arvense & 7 & 9 \\
\hline Sinapis arvensis & 6 & 5 \\
\hline Xanthium spinosum & 6 & 10 \\
\hline Cichorium intybus & 6 & 2 \\
\hline Chenopodium hybridum & 6 & 6 \\
\hline Papaver rhoeas & 6 & 3 \\
\hline Verbena officinalis & 6 & 3 \\
\hline Carduus acanthoides & 5 & 3 \\
\hline
\end{tabular}

\section{V38}

\begin{tabular}{|c|c|c|}
\hline Species name & Frequency & Mip \\
\hline Elymus repens & 41 & 15 \\
\hline Artemisia vulgaris & 39 & 13 \\
\hline Cirsium arvense & 26 & 4 \\
\hline Achillea millefolium & 22 & 3 \\
\hline Dactylis glomerata & 20 & 4 \\
\hline Urtica dioica & 20 & 7 \\
\hline Conyza canadensis & 19 & 5 \\
\hline Plantago lanceolata & 18 & 3 \\
\hline Echium vulgare & 16 & 6 \\
\hline Cichorium intybus & 15 & 3 \\
\hline Bromus inermis & 14 & 26 \\
\hline Lactuca serriola & 13 & 3 \\
\hline Hypericum perforatum & 13 & 3 \\
\hline Silene latifolia subsp. alba & 13 & 3 \\
\hline Tussilago farfara & 12 & 20 \\
\hline Melilotus alba & 12 & 17 \\
\hline
\end{tabular}




\begin{tabular}{|c|c|c|}
\hline Species name & Frequency & Mip \\
\hline Chenopodium album & 12 & 3 \\
\hline Lolium perenne & 12 & 4 \\
\hline Carduus acanthoides & 12 & 9 \\
\hline Artemisia absinthium & 11 & 13 \\
\hline Poa angustifolia & 11 & 7 \\
\hline Plantago major & 11 & 3 \\
\hline Arrhenatherum elatius & 11 & 6 \\
\hline Taraxacum sect. Ruderalia & 11 & 2 \\
\hline Poa compressa & 11 & 8 \\
\hline Cirsium vulgare & 11 & 4 \\
\hline Linaria vulgaris & 11 & 3 \\
\hline Melilotus officinalis & 11 & 9 \\
\hline Picris hieracioides & 10 & 5 \\
\hline Tripleurospermum perforatum & 10 & 4 \\
\hline Ballota nigra & 10 & 8 \\
\hline Taraxacum officinale & 10 & 3 \\
\hline Trifolium repens & 10 & 3 \\
\hline Equisetum arvense & 9 & 6 \\
\hline Berteroa incana & 9 & 7 \\
\hline Poa pratensis & 9 & 4 \\
\hline Galium verum & 9 & 3 \\
\hline Rumex crispus & 9 & 2 \\
\hline Capsella bursa-pastoris & 8 & 3 \\
\hline Arctium lappa & 8 & 11 \\
\hline Rumex obtusifolius & 8 & 11 \\
\hline Vicia cracca & 7 & 3 \\
\hline Potentilla argentea & 7 & 6 \\
\hline Trifolium pratense & 7 & 3 \\
\hline Polygonum aviculare & 7 & 4 \\
\hline Bromus sterilis & 7 & 5 \\
\hline Euphorbia esula subsp. tommasiniana & 7 & 2 \\
\hline Galium aparine & 7 & 3 \\
\hline Erigeron annuus & 7 & 7 \\
\hline Lotus corniculatus & 7 & 2 \\
\hline Eryngium campestre & 6 & 3 \\
\hline Senecio jacobaea & 6 & 3 \\
\hline Pastinaca sativa & 6 & 4 \\
\hline Onopordum acanthium & 6 & 25 \\
\hline Poa annua & 6 & 4 \\
\hline Bromus tectorum & 6 & 5 \\
\hline Falcaria vulgaris & 6 & 7 \\
\hline Poa trivialis & 6 & 4 \\
\hline Reseda lutea & 6 & 4 \\
\hline Sonchus oleraceus & 5 & 2 \\
\hline Potentilla reptans & 5 & 4 \\
\hline Arctium minus & 5 & 8 \\
\hline Arenaria serpyllifolia & 5 & 4 \\
\hline Rubus caesius & 5 & 3 \\
\hline Agrostis capillaris & 5 & 5 \\
\hline Sonchus arvensis & 5 & 5 \\
\hline Arctium tomentosum & 5 & 9 \\
\hline Solidago canadensis & 5 & 12 \\
\hline Ranunculus repens & 5 & 4 \\
\hline Euphorbia cyparissias & 5 & 3 \\
\hline Carex praecox & 5 & 9 \\
\hline Cardaria draba & 5 & 15 \\
\hline Galium mollugo & 5 & 3 \\
\hline Inula britannica & 5 & 2 \\
\hline
\end{tabular}


Festuca rubra

Malva sylvestris

Silene vulgaris

Oenothera biennis

Medicago sativa subsp. falcata

\begin{tabular}{ll}
5 & 5 \\
5 & 6 \\
\hline 5 & 4 \\
5 & 4 \\
\hline 5 & 4 \\
5 & 4
\end{tabular}

\section{V39}

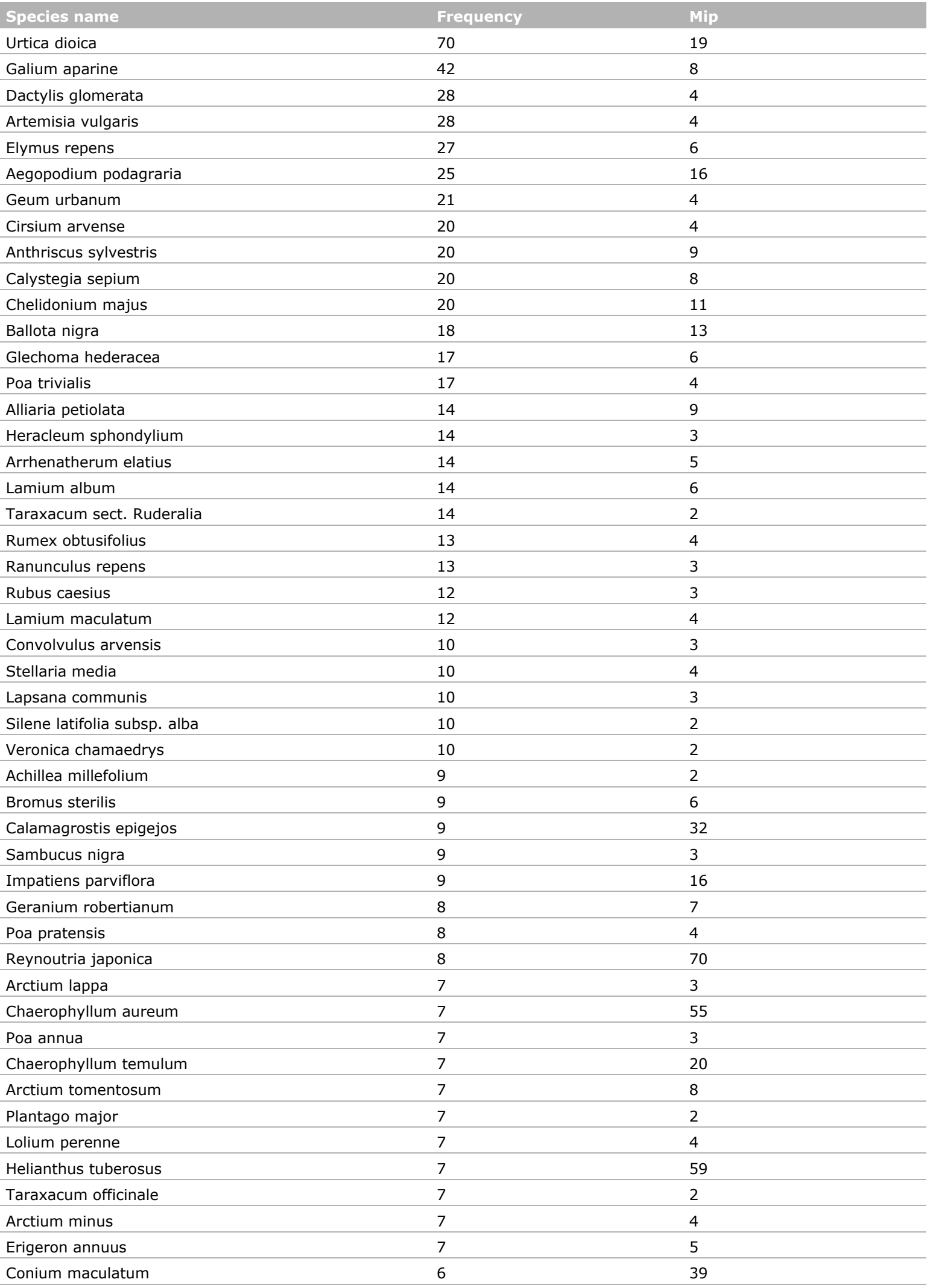




\begin{tabular}{|c|c|c|}
\hline Species name & Frequency & Mip \\
\hline Chaerophyllum bulbosum & 6 & 35 \\
\hline Potentilla reptans & 6 & 3 \\
\hline Vicia cracca & 6 & 2 \\
\hline Galeopsis tetrahit & 6 & 4 \\
\hline Equisetum arvense & 5 & 3 \\
\hline Humulus lupulus & 5 & 5 \\
\hline Torilis japonica & 5 & 13 \\
\hline Carduus crispus & 5 & 5 \\
\hline Galium album & 5 & 2 \\
\hline Capsella bursa-pastoris & 5 & 2 \\
\hline Phragmites australis & 5 & 14 \\
\hline Sisymbrium officinale & 5 & 2 \\
\hline Phalaris arundinacea & 5 & 4 \\
\hline Galium mollugo & 5 & 3 \\
\hline Sonchus oleraceus & 5 & 2 \\
\hline
\end{tabular}




\section{Annex 6 Summary of traits (binary categories) for use in QUICKScan.}

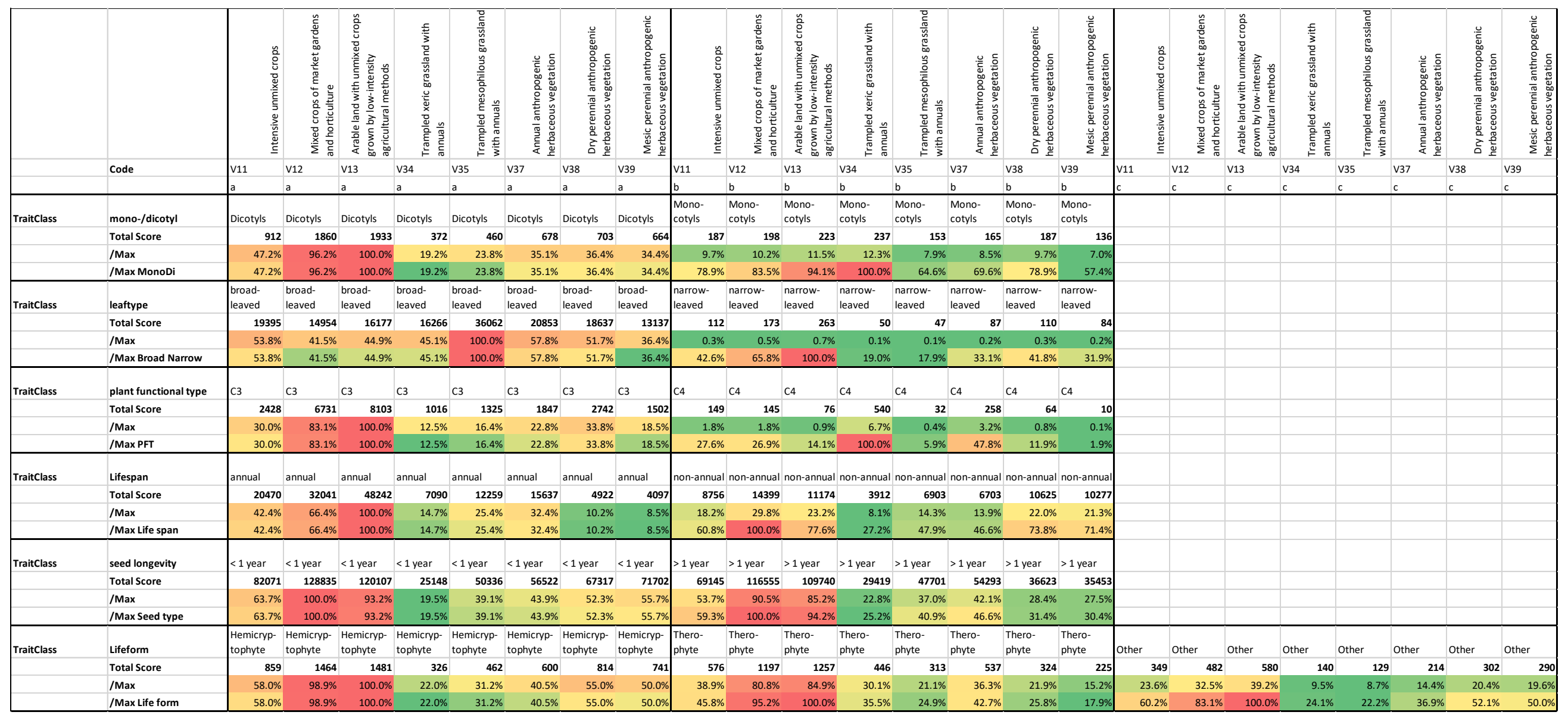




\section{Annex $7 \quad 47$ maps including suitability maps for the eight EUNIS habitats, the potential occurrence maps of the eight EUNIS habitats in agricultural land surrounding wheat crops and surrounding vineyards and trait maps for the example trait annual vs non-annual}

Annex 7 includes 47 maps i.e. the habitat suitability maps for the eight EUNIS habitats, the potential occurrence maps of the eight EUNIS habitats in agricultural land surrounding wheat crops and in agricultural land surrounding vineyards and trait maps for the trait annual vs non-annual.

The maps are designed in such a way that the more intense the colour, the more suitable the habitat is supposed to be (habitat suitability maps), the higher the occurrence (potential occurrence maps) and the higher the representation of annual or non-annual species in the EUNIS habitat. 
Habitat suitability v-types

HABITAT SUITABILITY \% 


\section{V11 Habitat suitability}

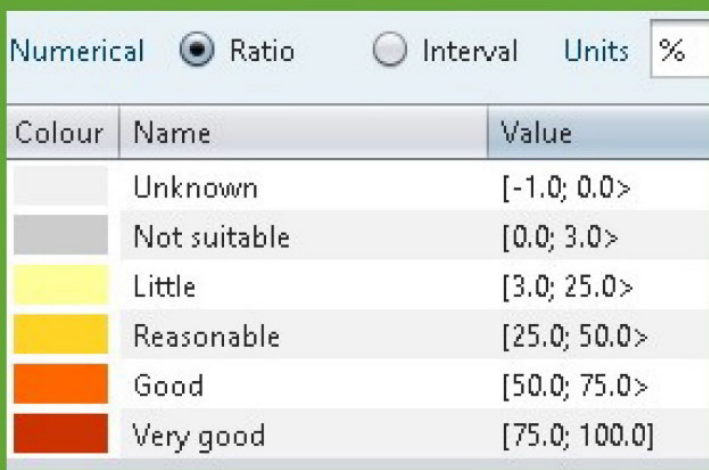

\section{$\bigsqcup_{\text {quickscan }}$}

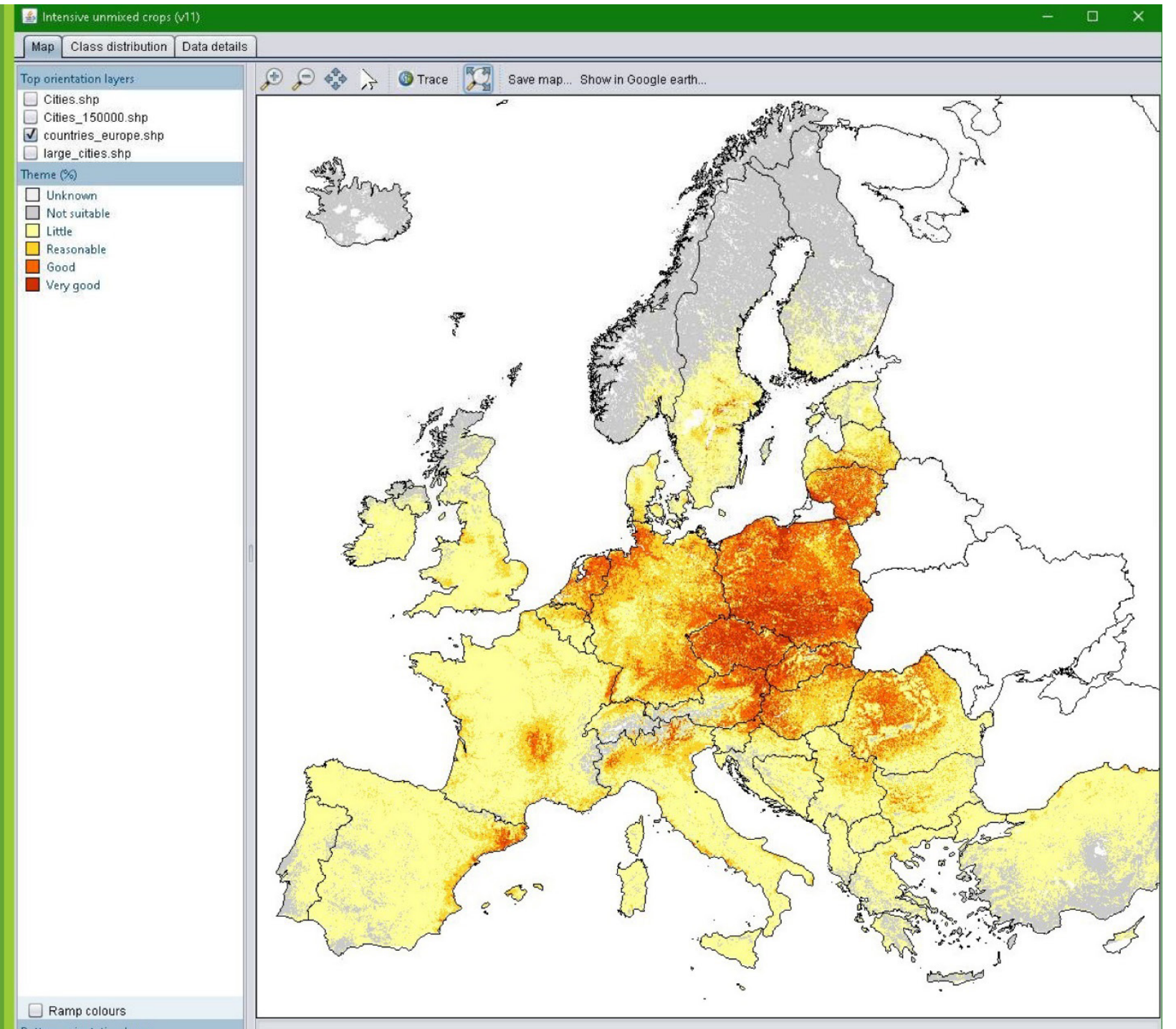


V12

Habitat

suitability

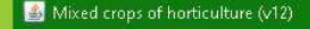

\begin{tabular}{|l|l|l|l|l|l|l}
\hline Map Class distribution & Data details \\
\hline
\end{tabular}

Top orientotion layers

$\square$ Cities.shp

Cities_150000.shp
countries_europe.shp

$\checkmark$ large_cities.shp

Theme (\%)

Gunkown

Little

Reasonable

Q Very good

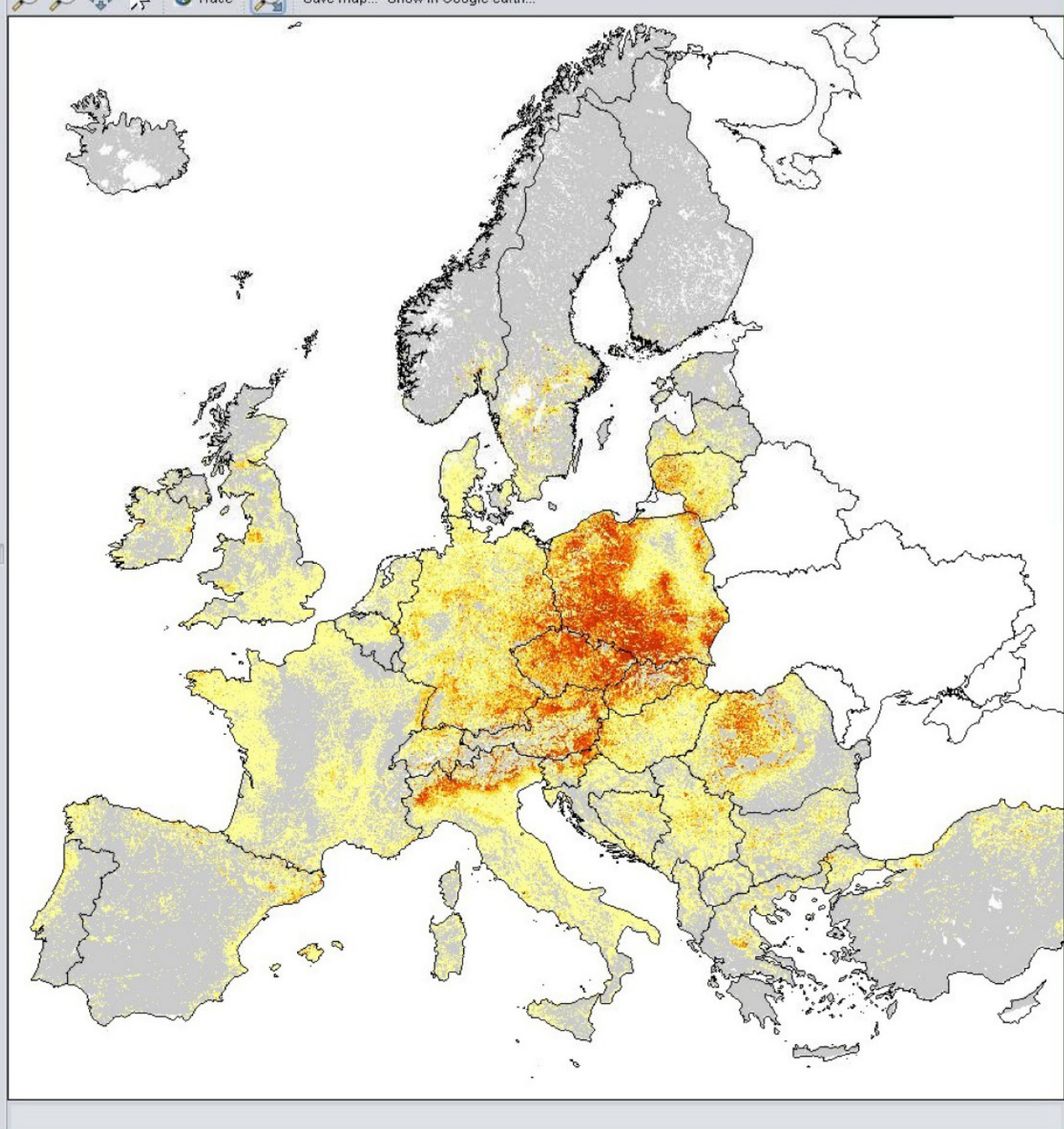


V13

Habitat

suitability
G. Low intensity unmixed crops (M13)

distribution Data details

Top orientation lay

Cities_150000.shp

V countries_europe.shp

Theme ${ }^{\circ}$ )

$\square$ Unknown

Little

Reasonable

Very good

$\underset{\text { quickscan }}{\square}$

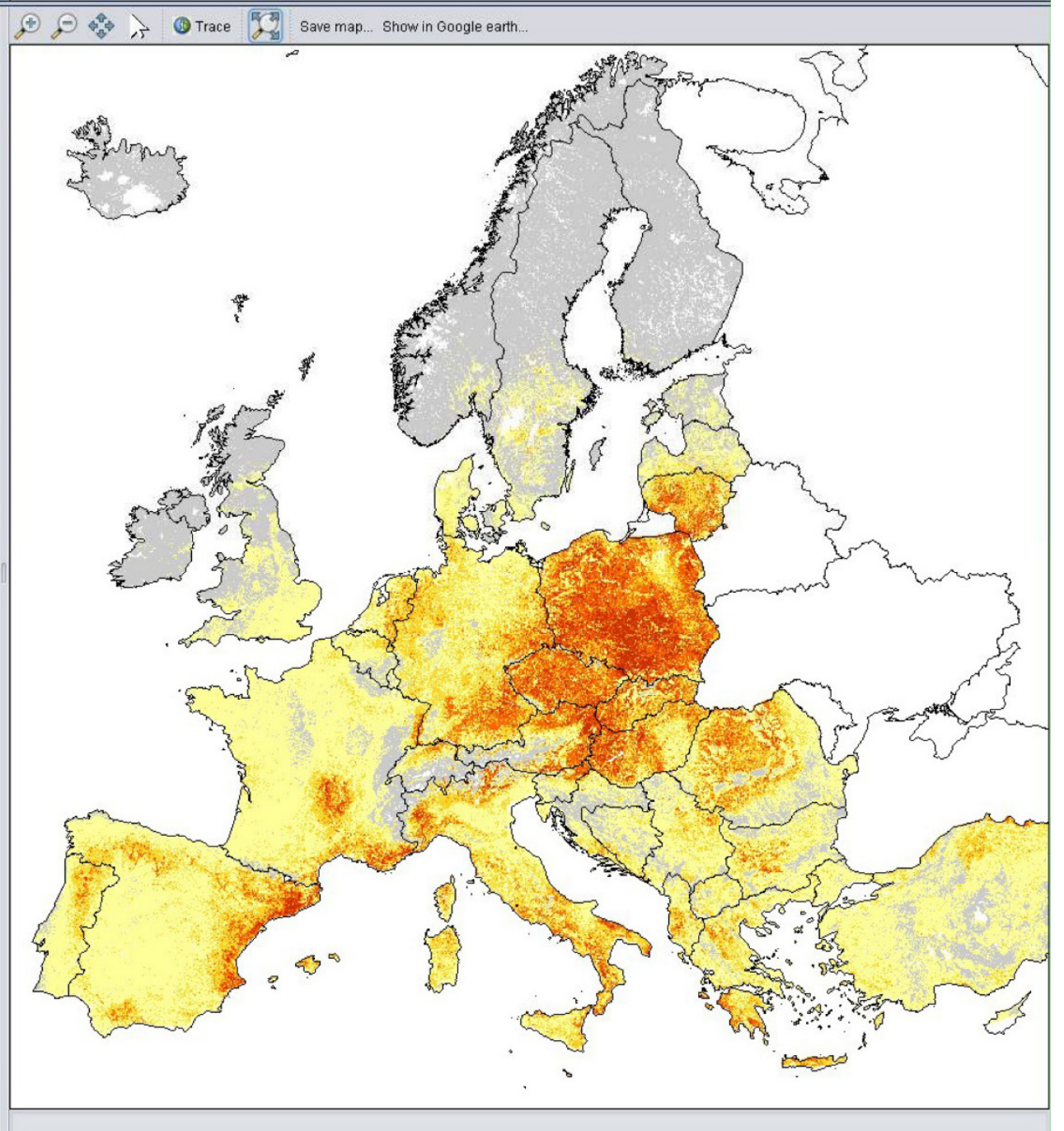




\section{V34} Habitat suitability

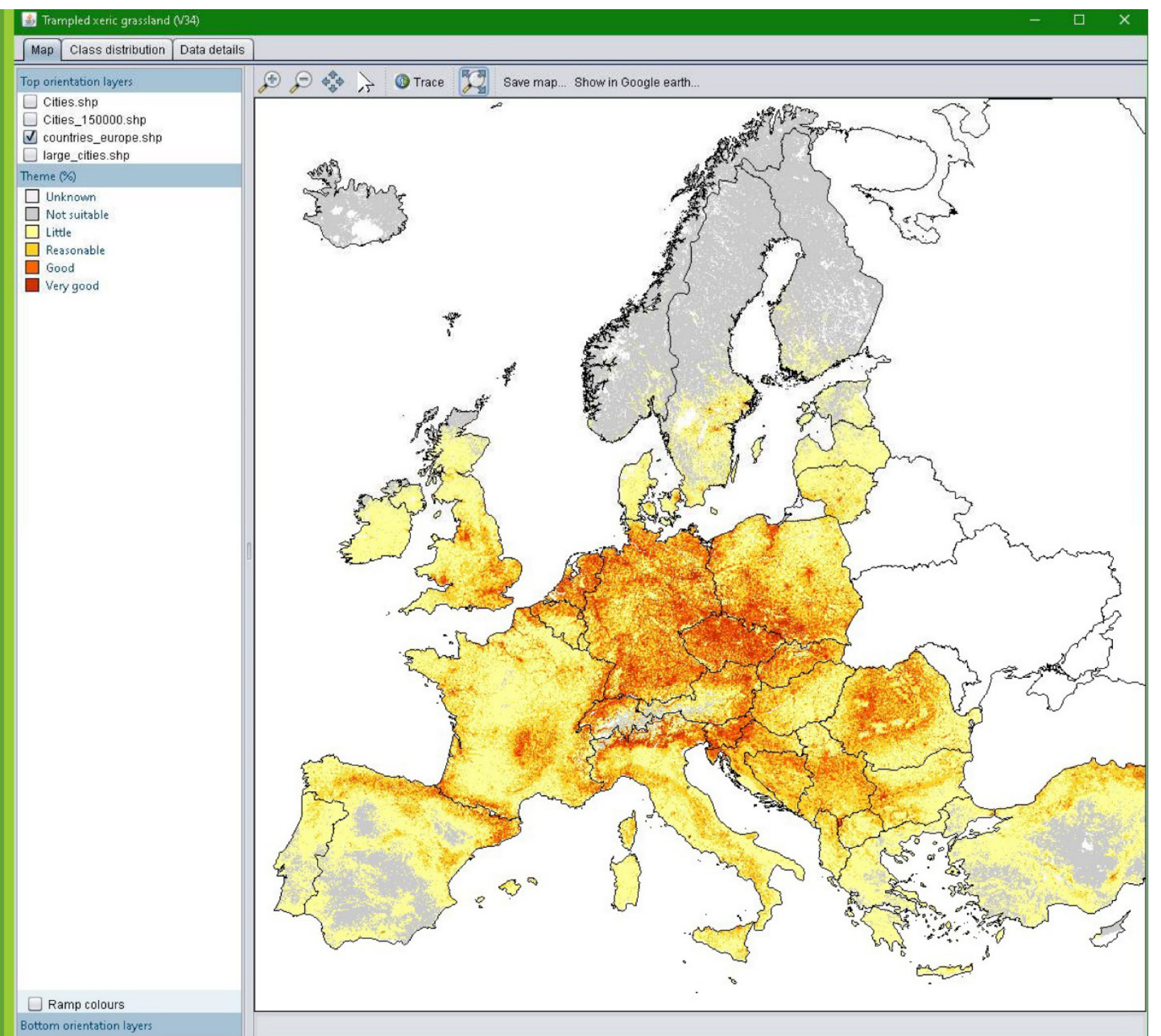

$\underset{\text { quickscan }}{\square}$ 
V35 Habitat suitability

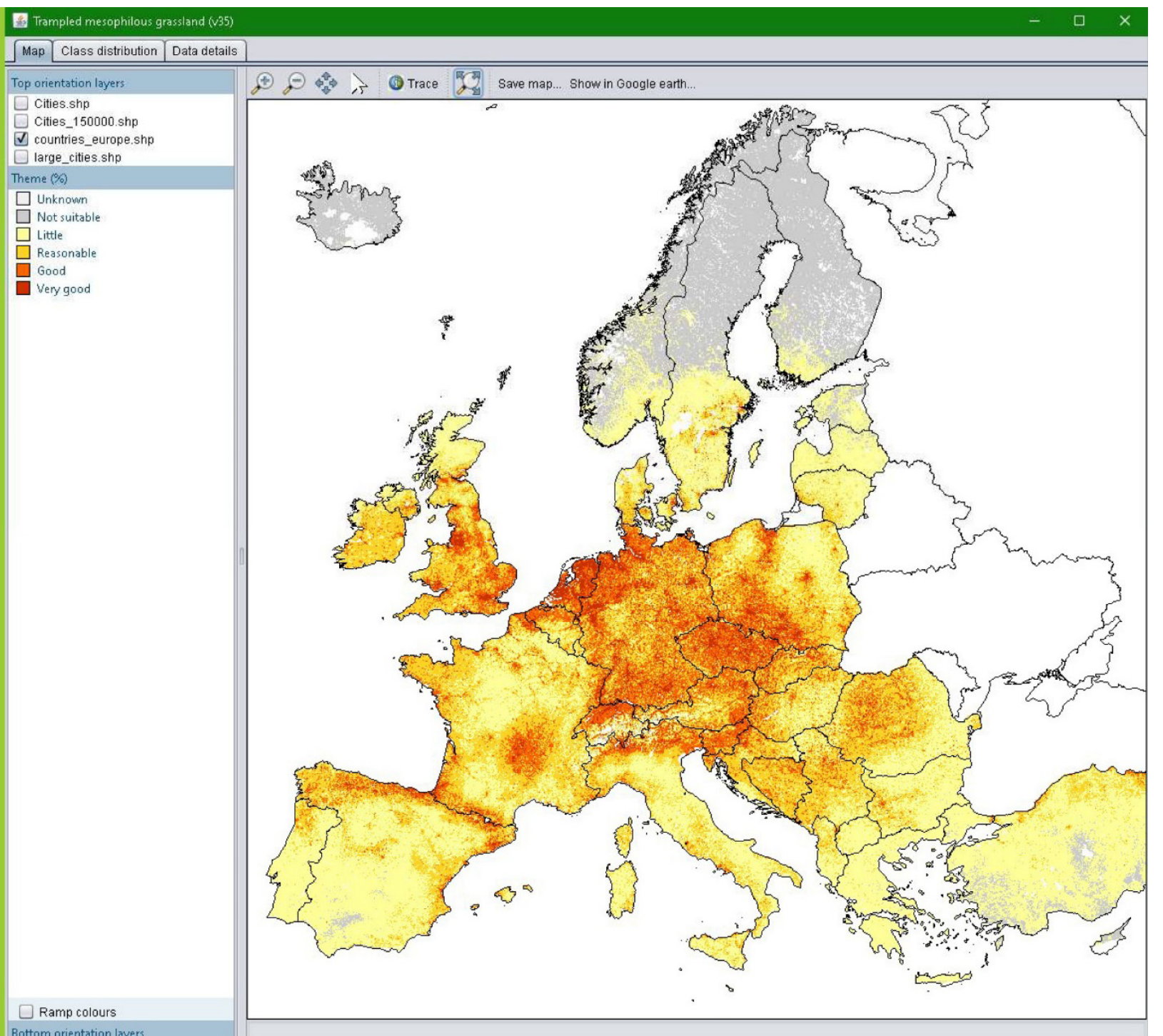


V37

Habitat

suitability

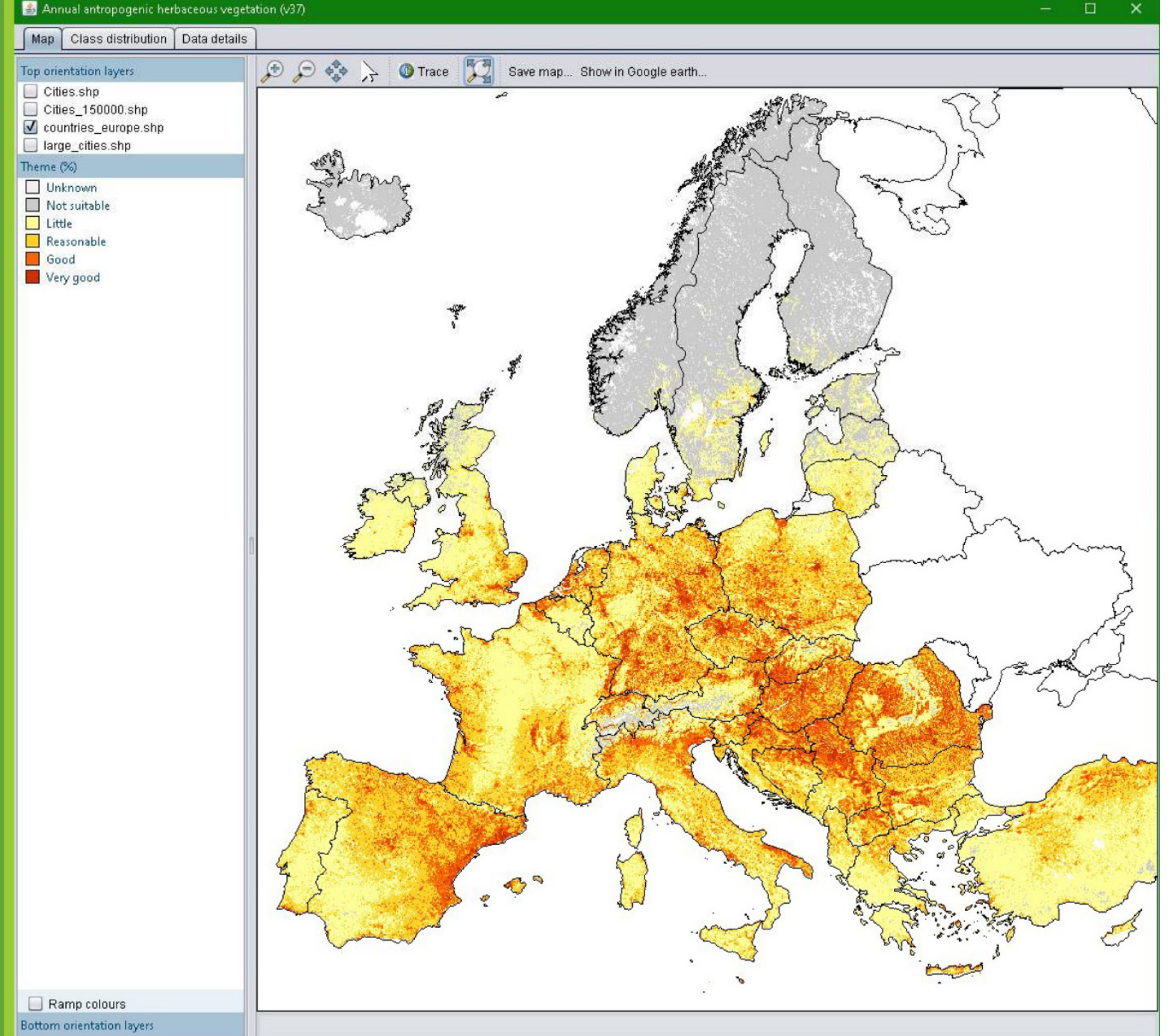

$\underset{\text { quickscan }}{\square}$ 
V38

\section{Habitat}

suitability
B. Diy perrennial anthropogenic hebaceous
\begin{tabular}{|l} 
Map Class distribution \\
Data details
\end{tabular}

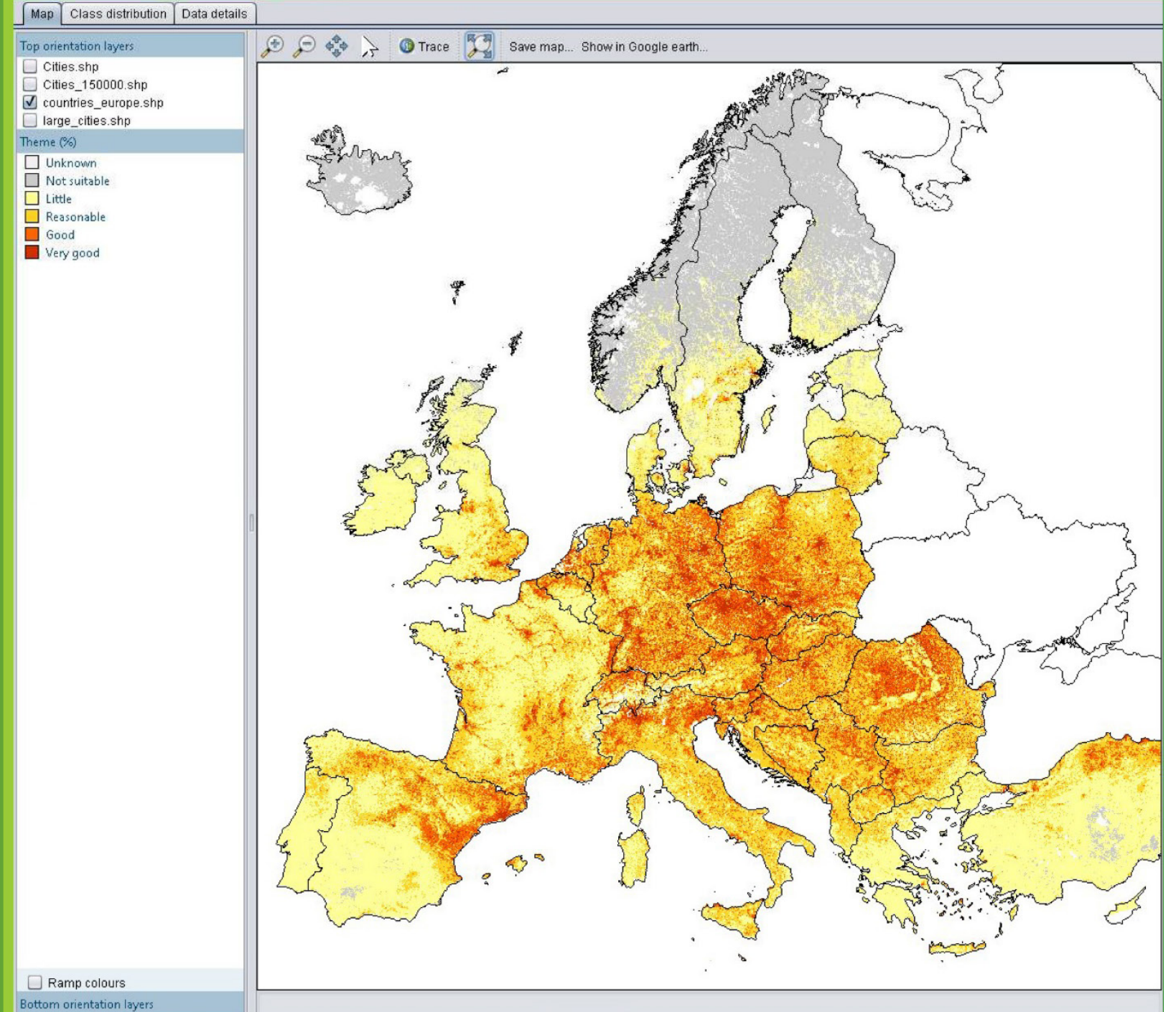


V39

\section{Habitat}

suitability

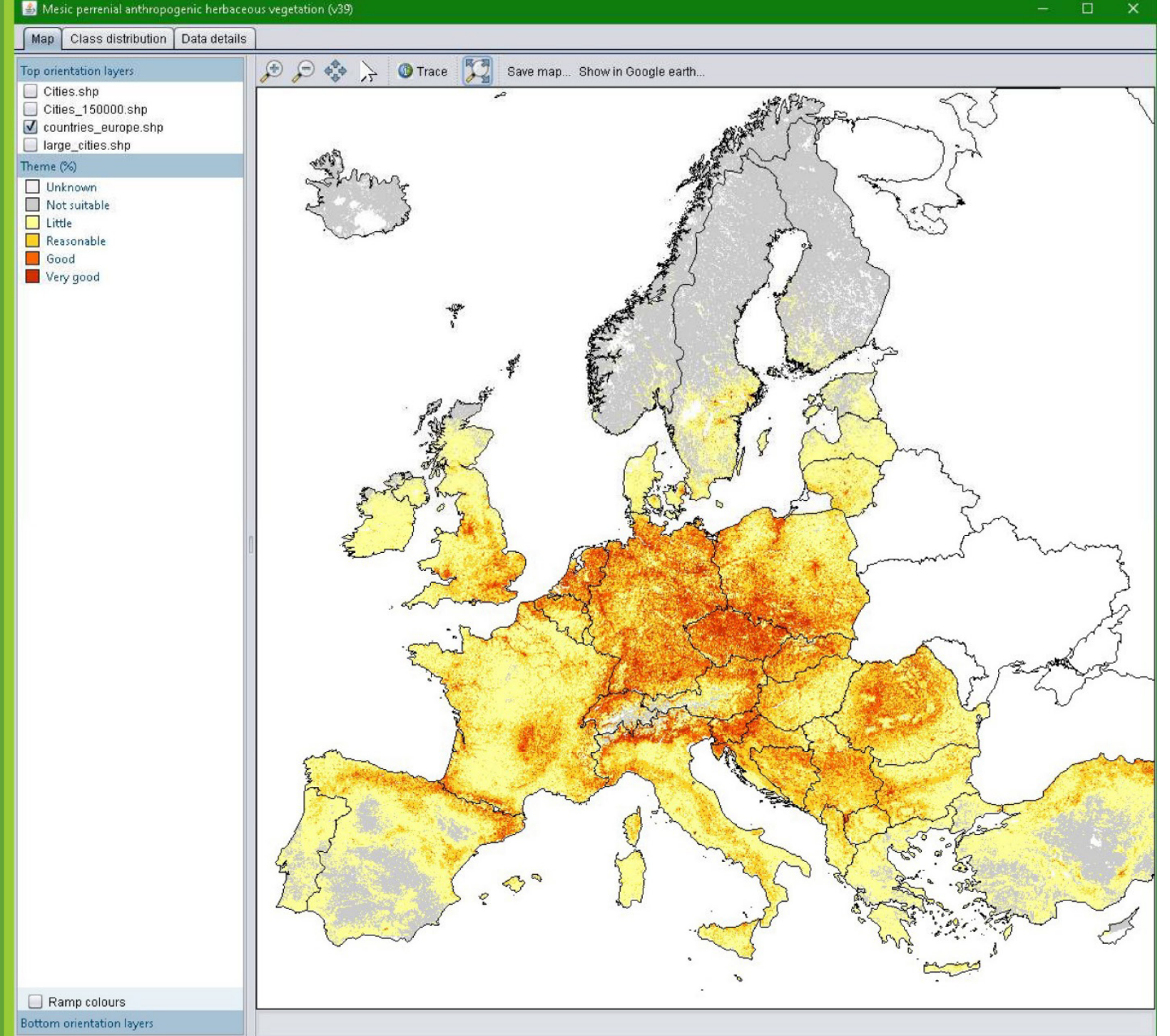


Cereals

HABITAT SUITABILITY \&

POTENTIAL OCCURRENCE (SUITABILITY X FSS2010-CROP PRESENCE) 


\section{Cereals FSS2010}

(\% ha / total ha crops)

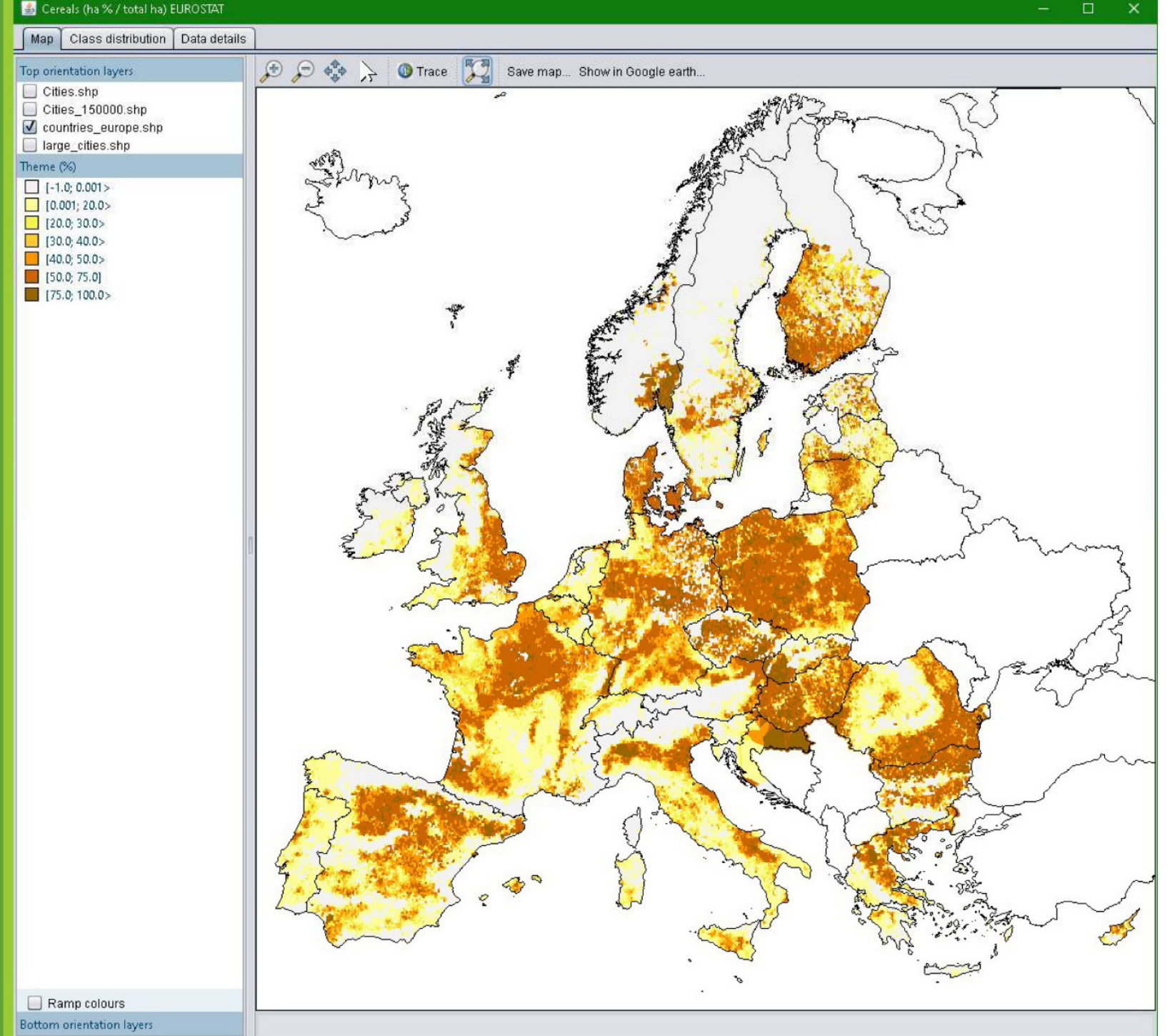




\section{Cereals FSS2010}

Agricultural Mask

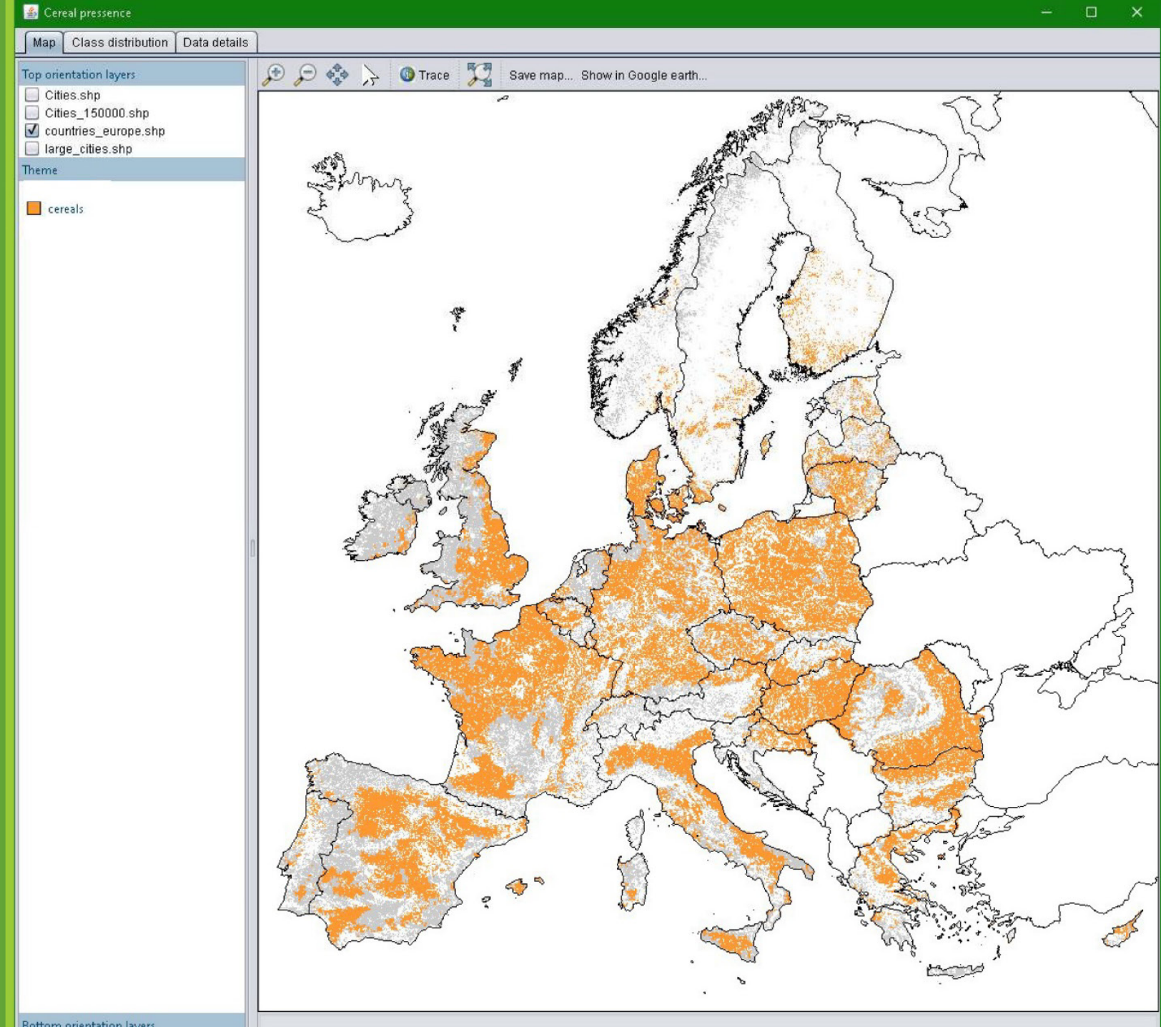




\section{V11 potential occurrence}

\begin{tabular}{|c|c|c|}
\hline \multicolumn{3}{|c|}{ Units 9} \\
\hline \multirow[t]{7}{*}{ Colour } & Name & Value \\
\hline & No agricultural area & {$[-1.0 ; 0.0>$} \\
\hline & No occurence expected & {$[0.0 ; 3.0>$} \\
\hline & Occurence possible & {$[3.0 ; 25.0>$} \\
\hline & Reasonable occurence c... & {$[25.0 ; 50.0>$} \\
\hline & High occurence chance & {$[50.0 ; 75.0>$} \\
\hline & Occurence probable & {$[75.0 ; 100.0]$} \\
\hline
\end{tabular}

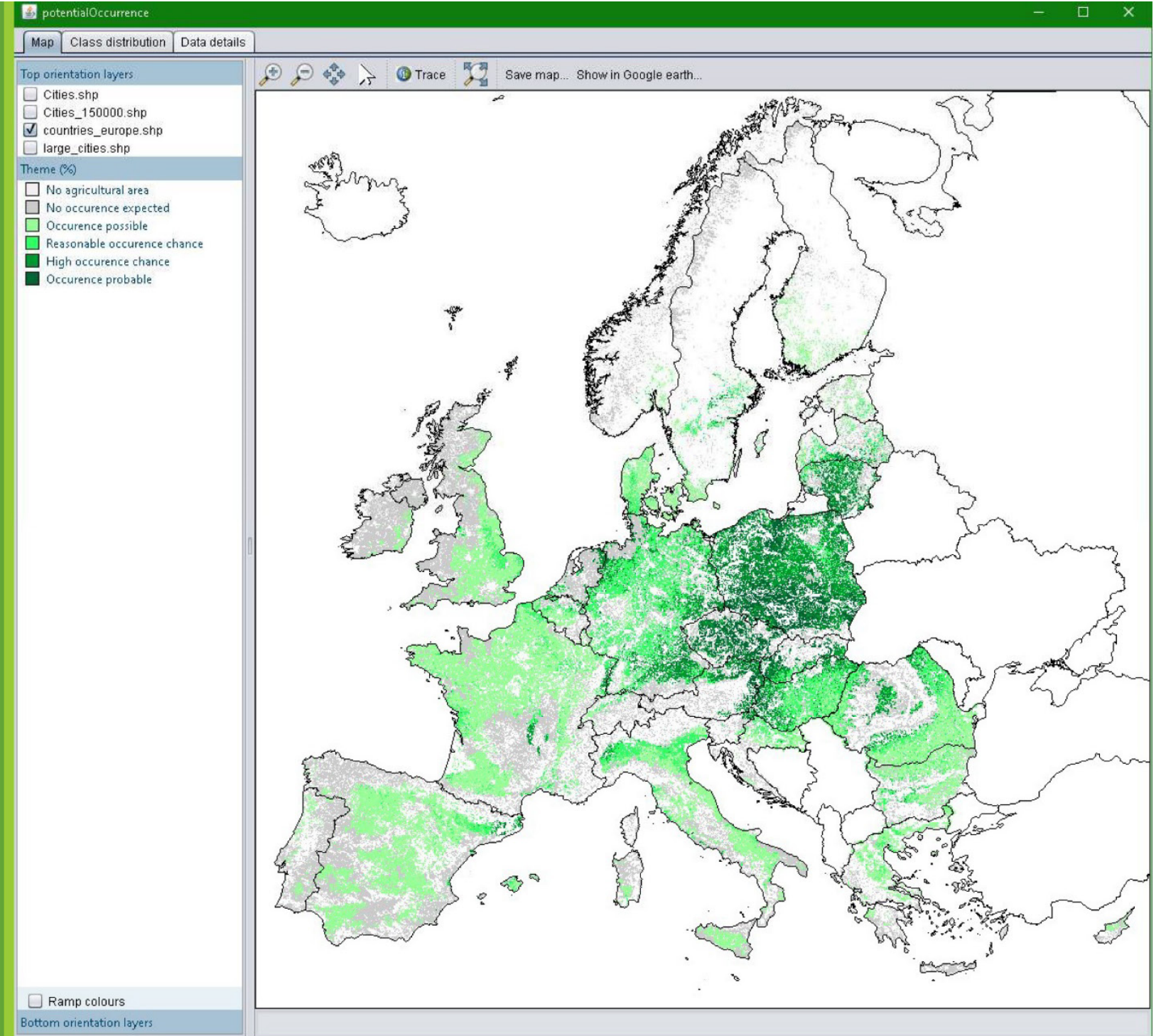




\section{V12}

potential occurrence

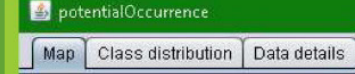

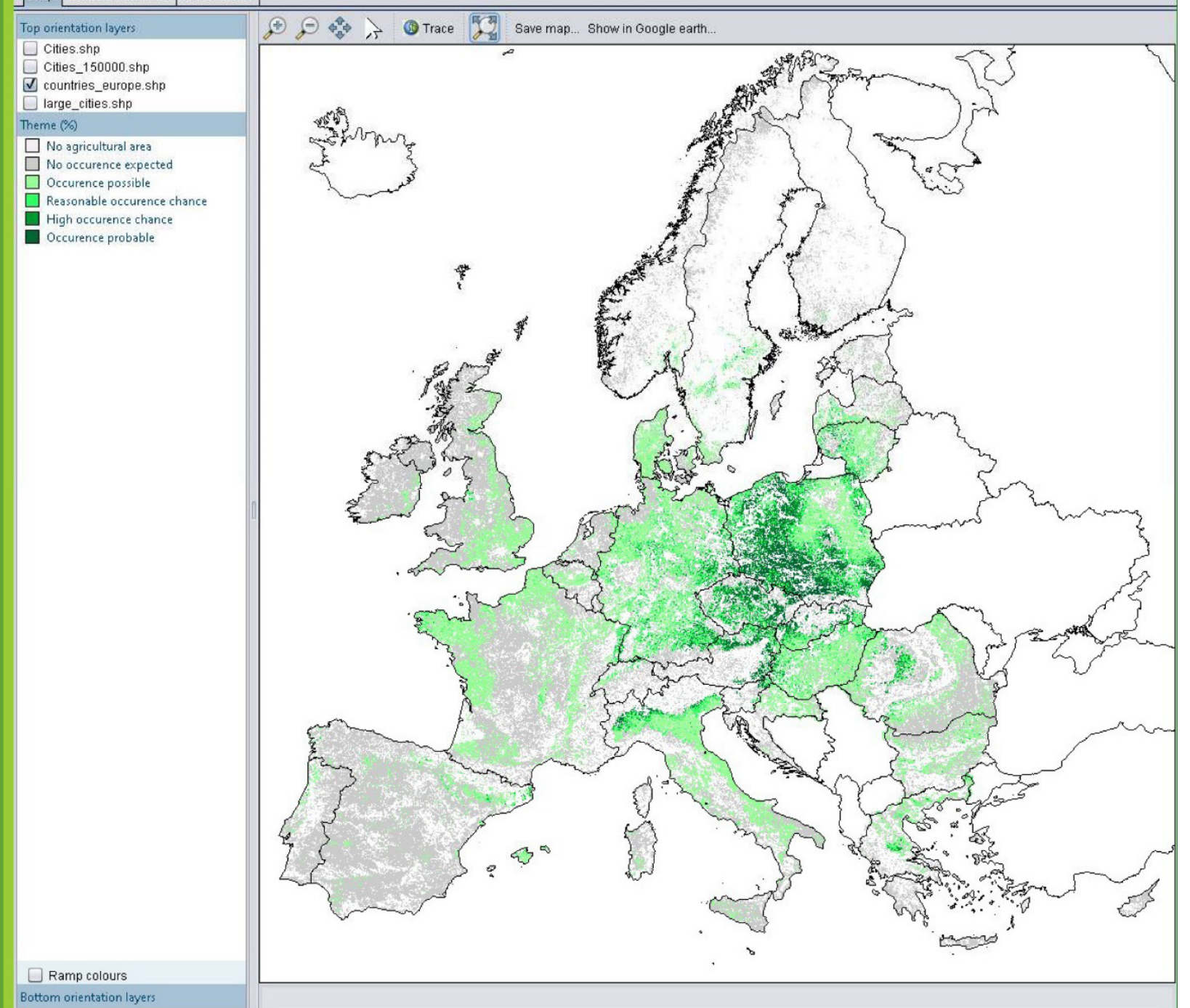




\section{V13}

potential occurrence

모곤

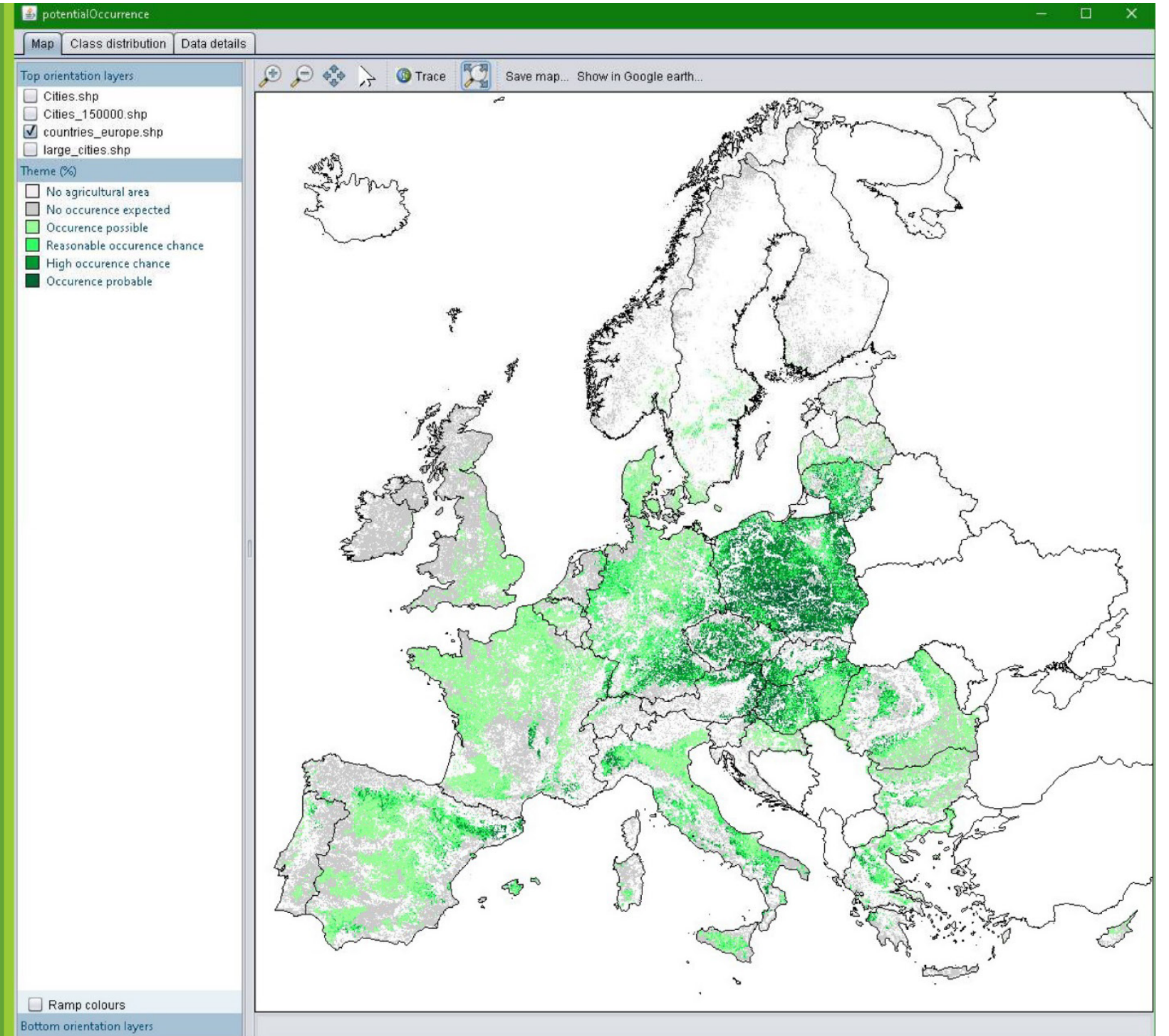




\section{V34} potential occurrence

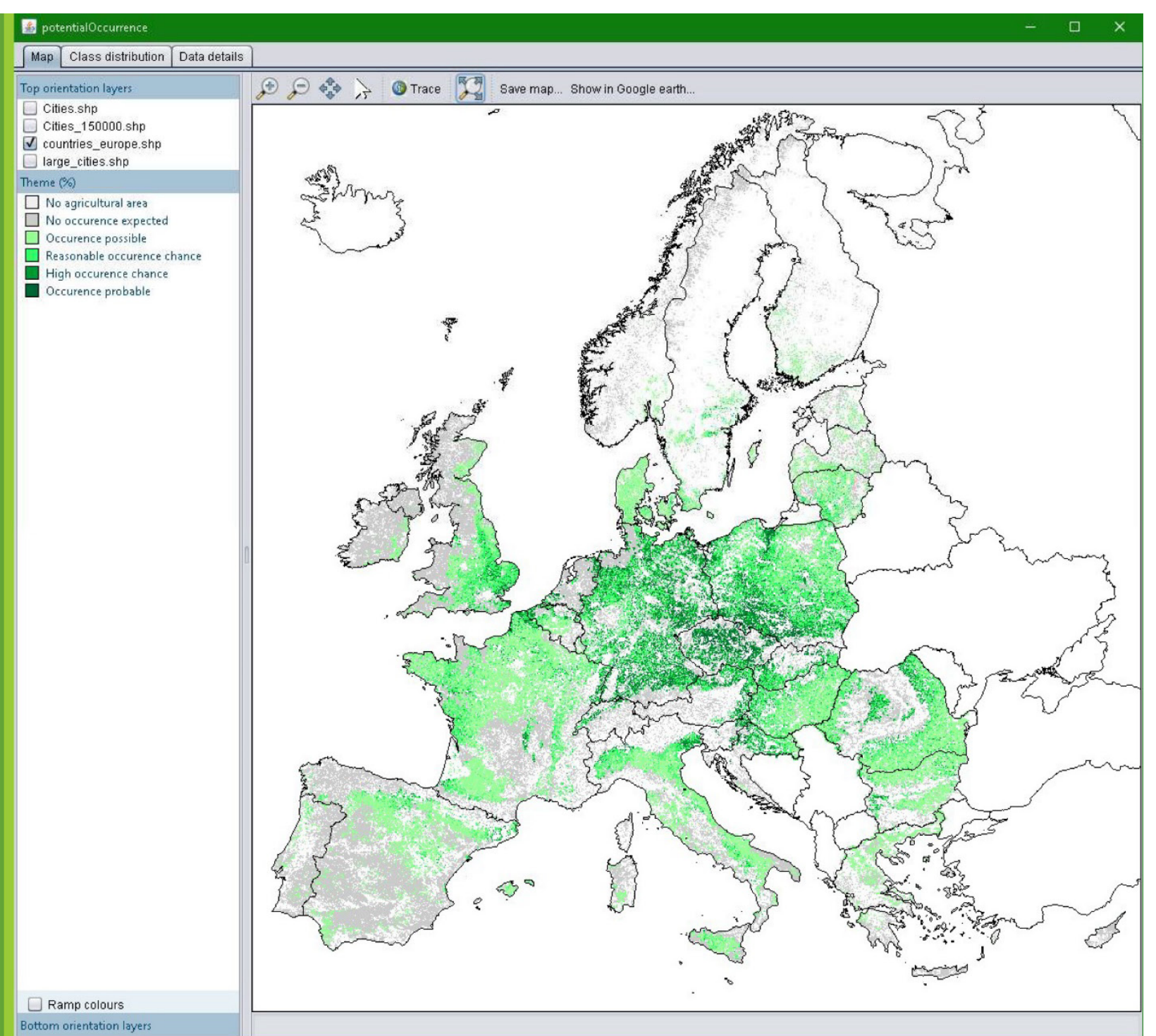




\section{V35} potential occurrence

매돈

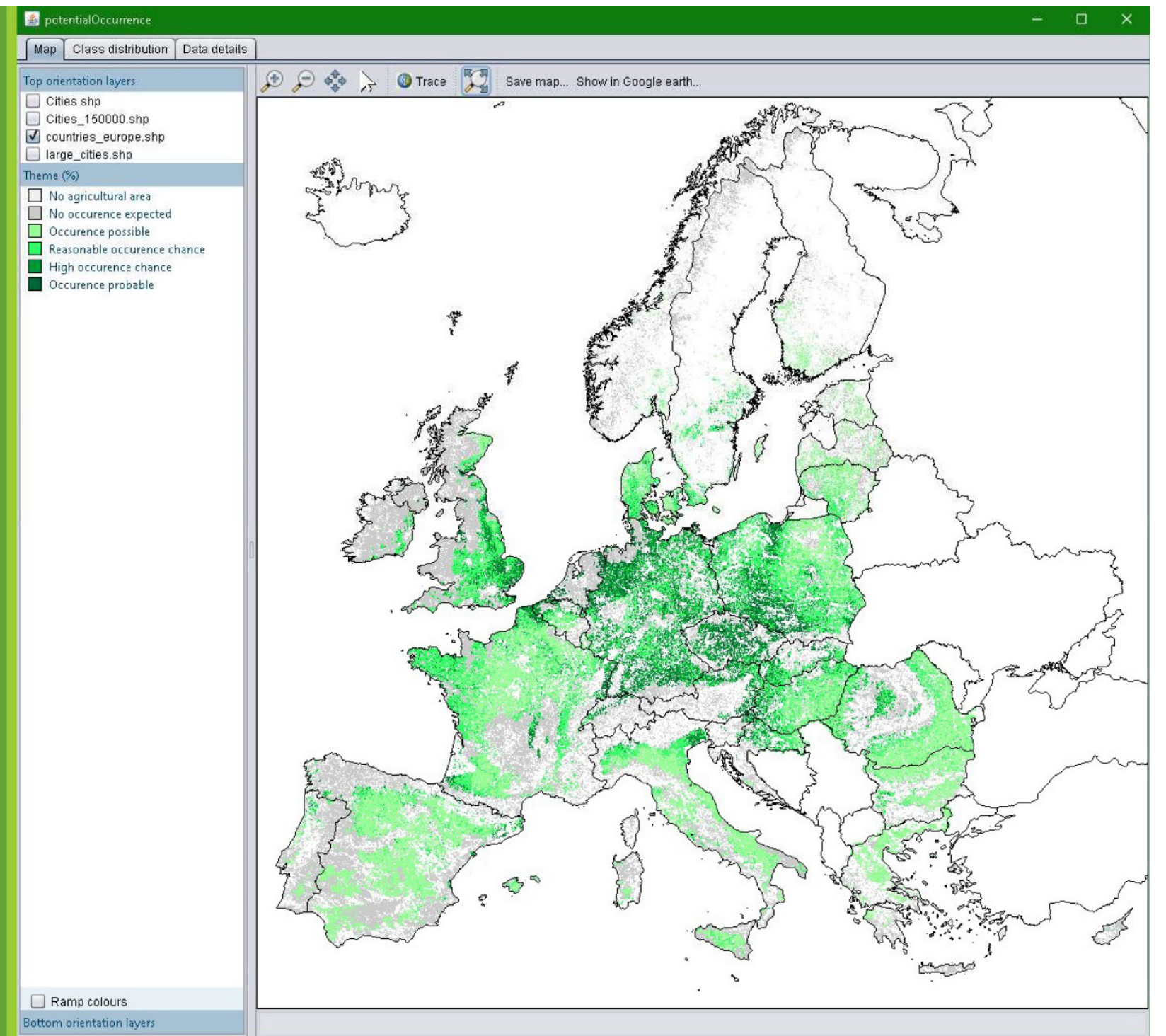




\section{V37}

potential

occurrence

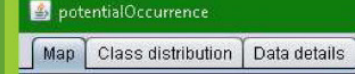

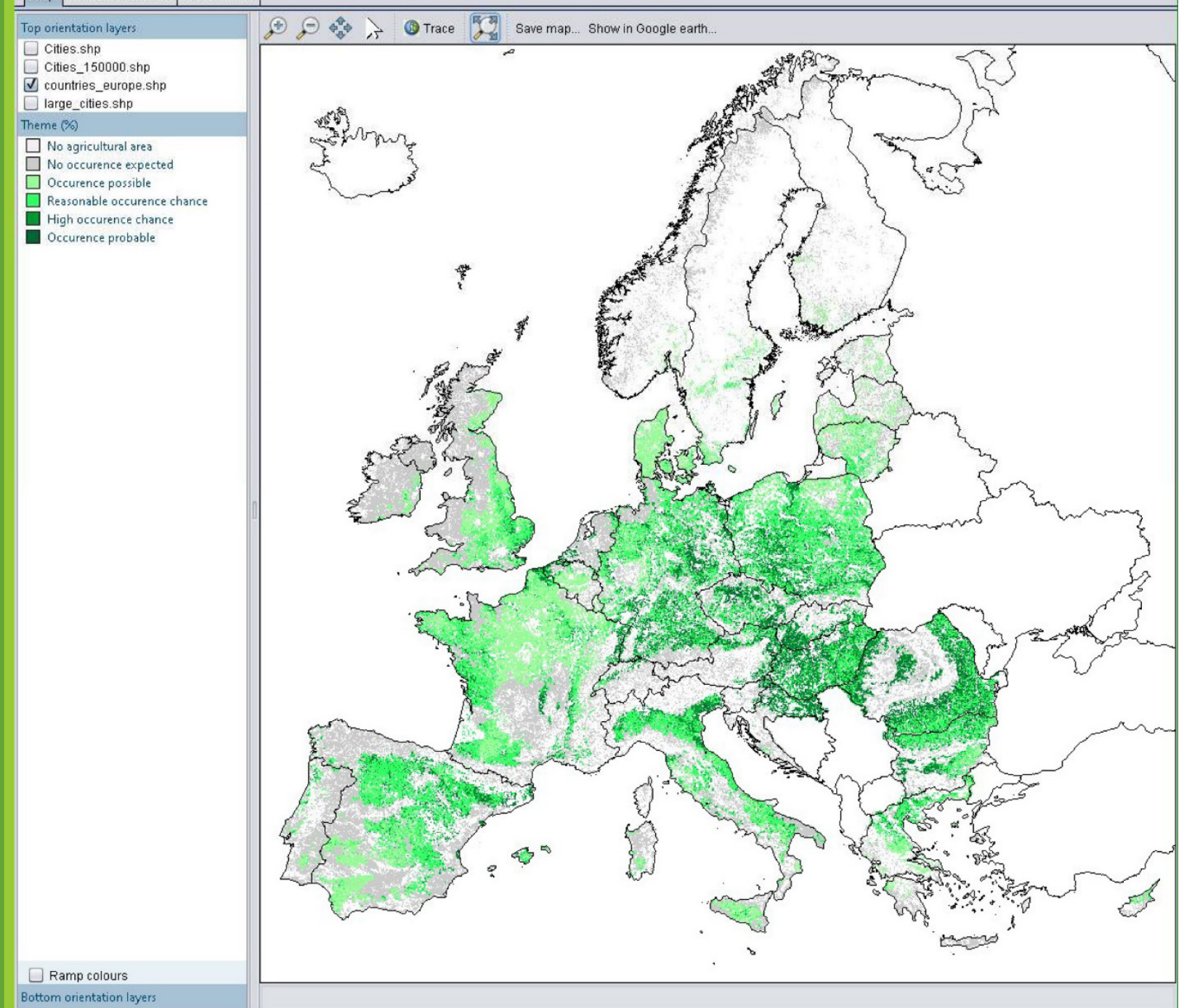




\section{V38} potential occurrence

매돈

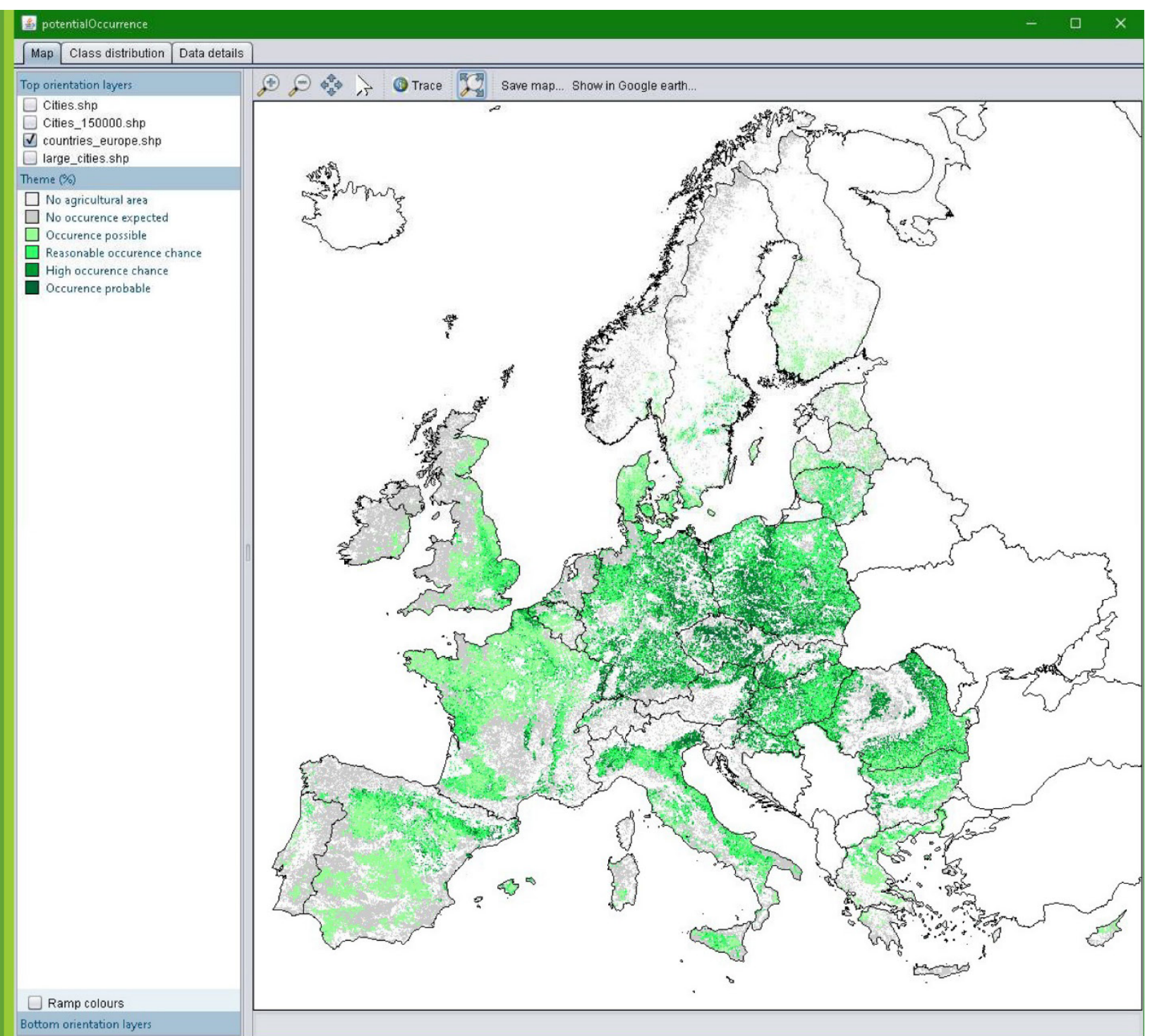


V39 potential occurrence

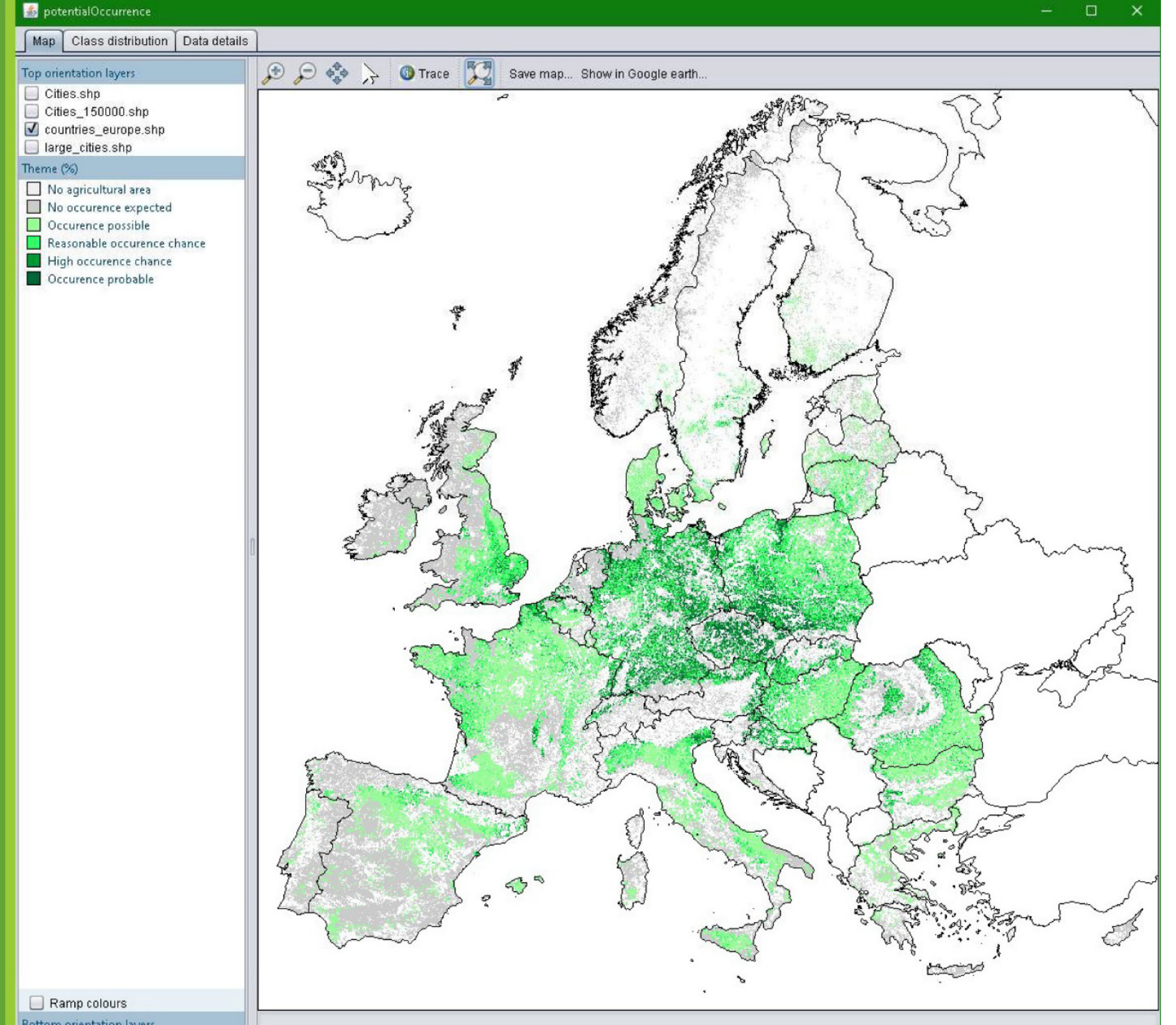




\section{Cereals}

TRAITS 


\section{V11 Traits Annual}

Theme (\%)
$\square<0$
$\square 0-1$
$\square 1-2$
$\square 2-5$
$\square 5-10$
$\square 10-15$
$\square 15-20$
$\square 20-30$
$\square 30-40$
$\square 40-50$
$\square 0-65$
$\square 6-80$
$80-100$

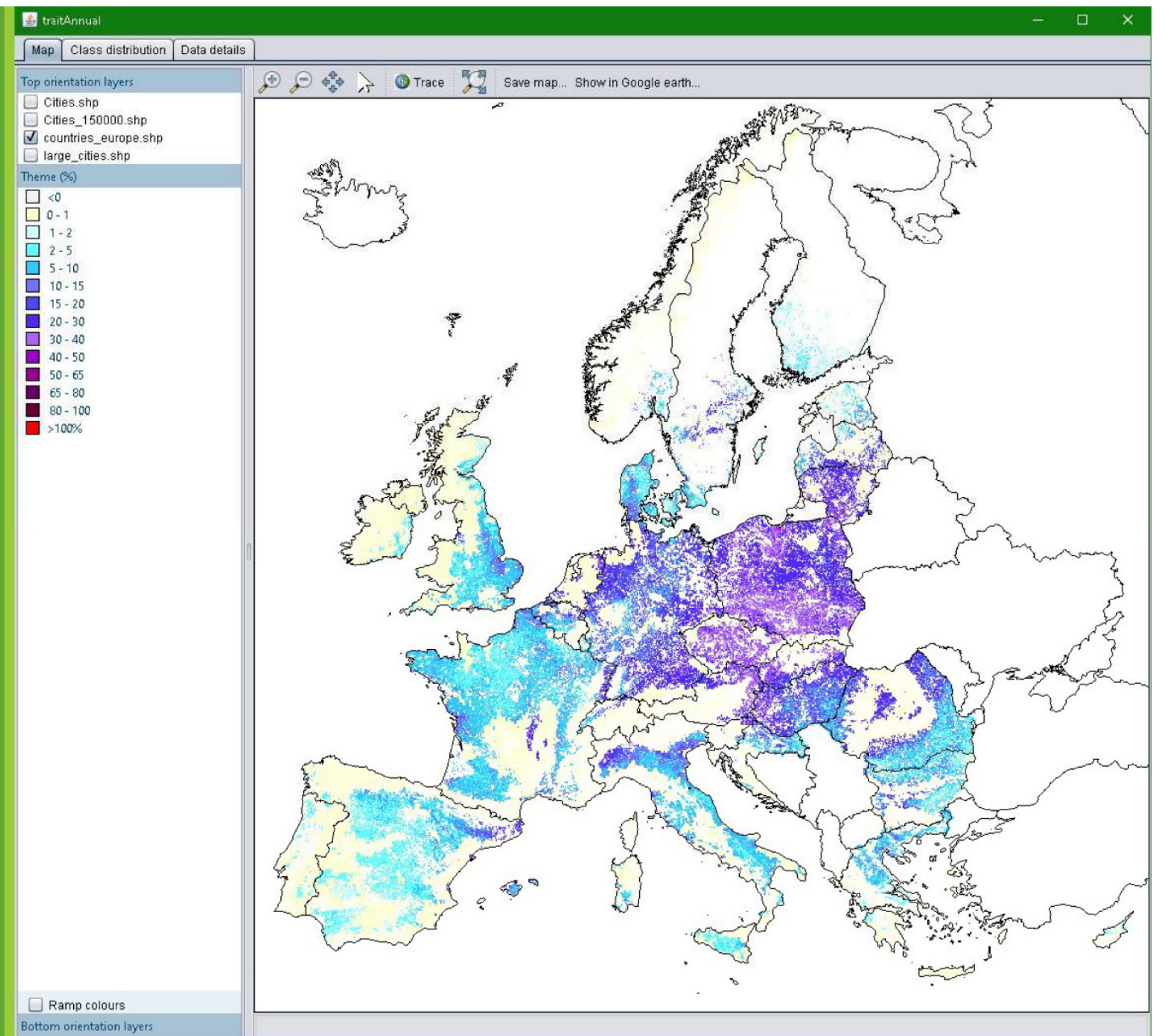




\section{V11 Traits \\ Non-annual}

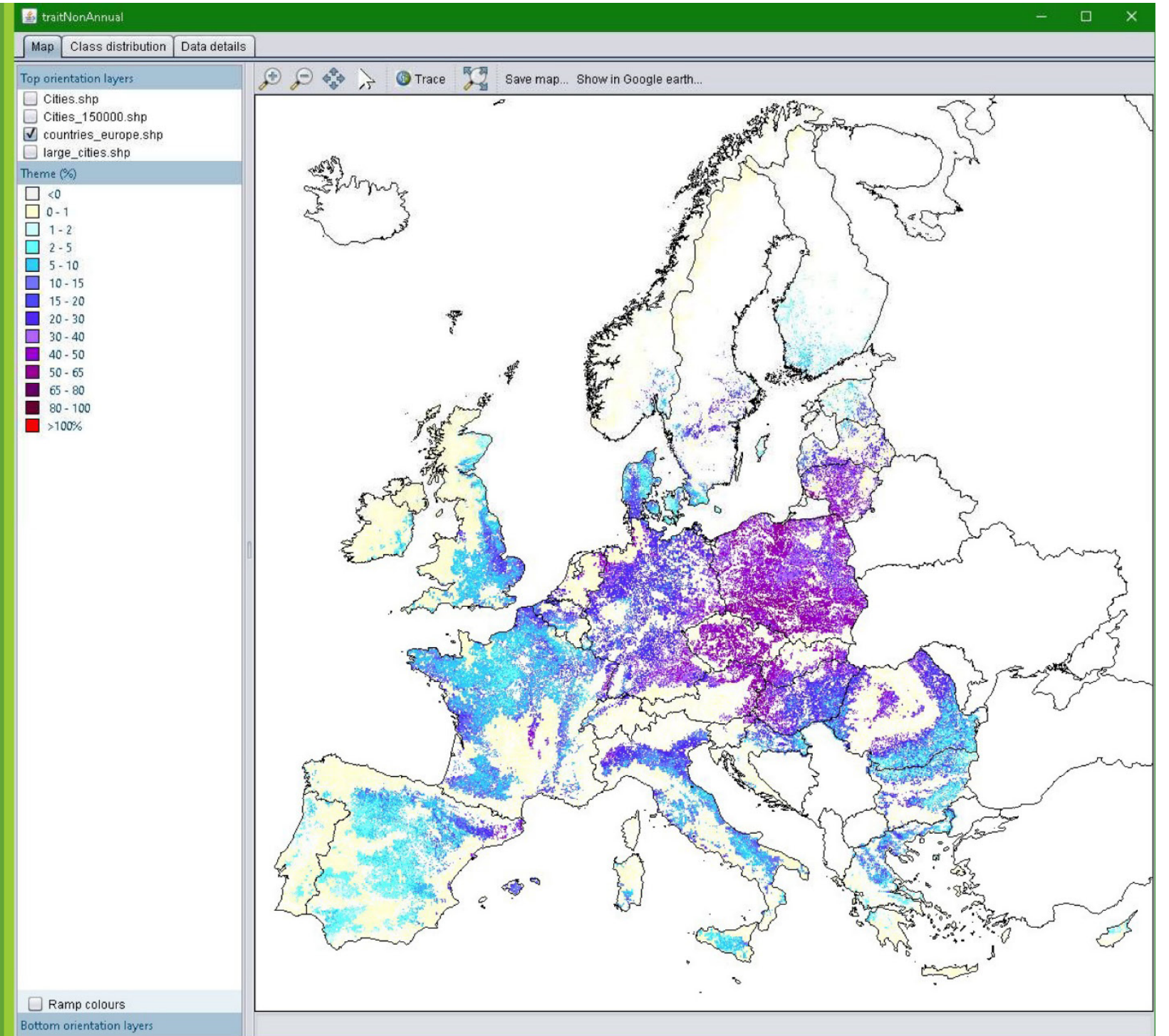

$\underset{\text { quickscan }}{\square}$ 


\section{V12 Traits Annual}

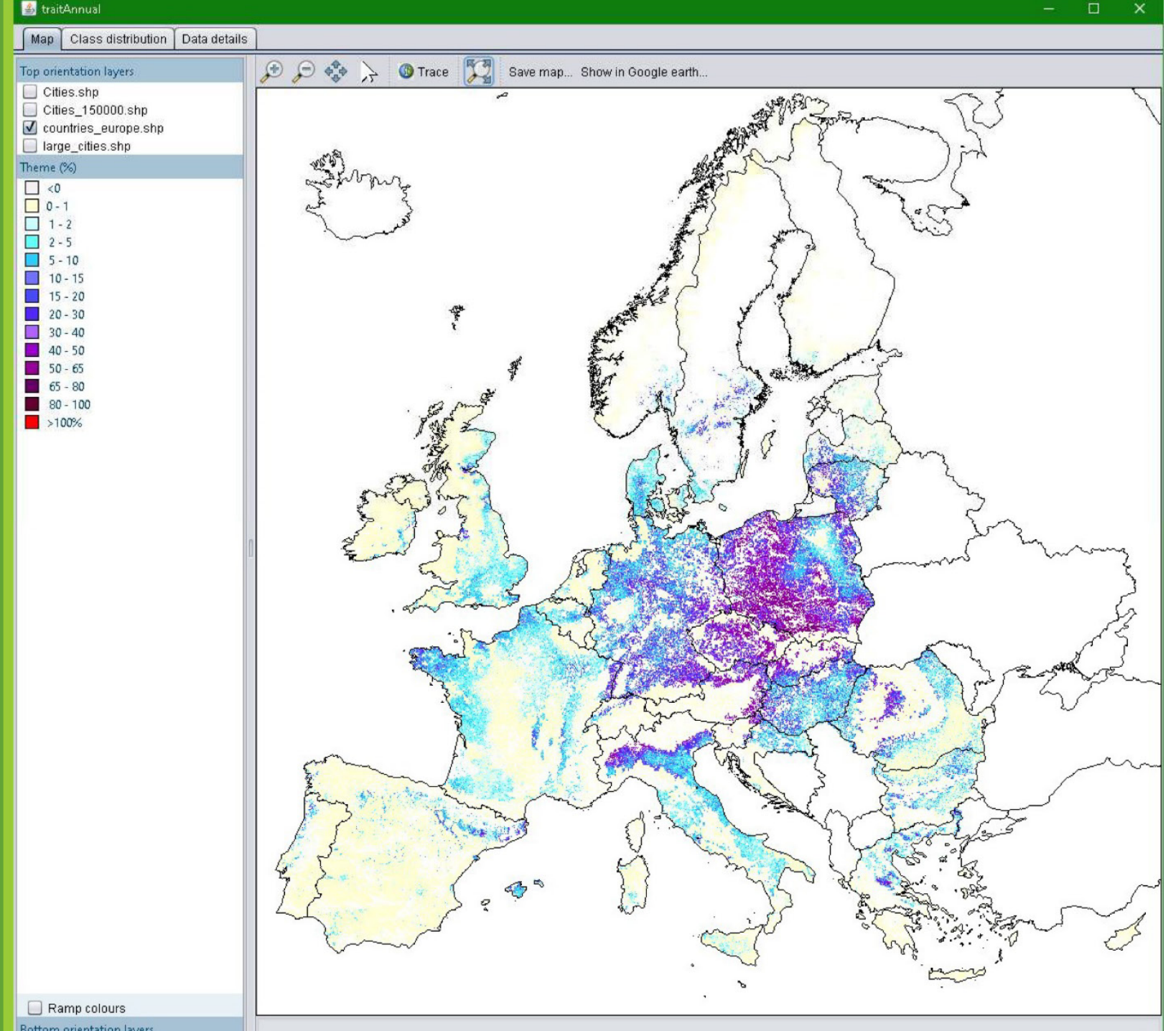




\section{V12 Traits Non-annual}

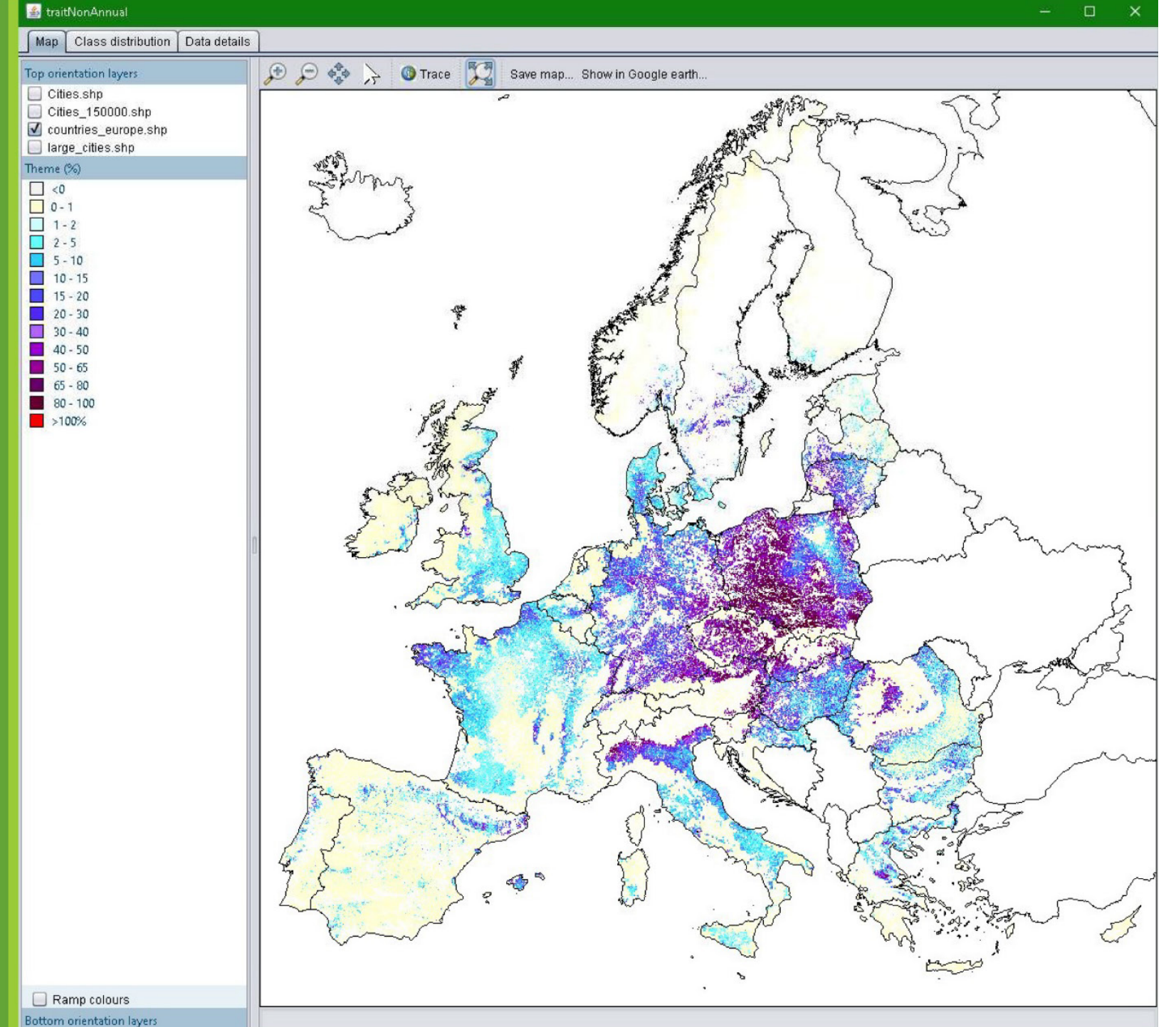




\section{V13 Traits Annual}

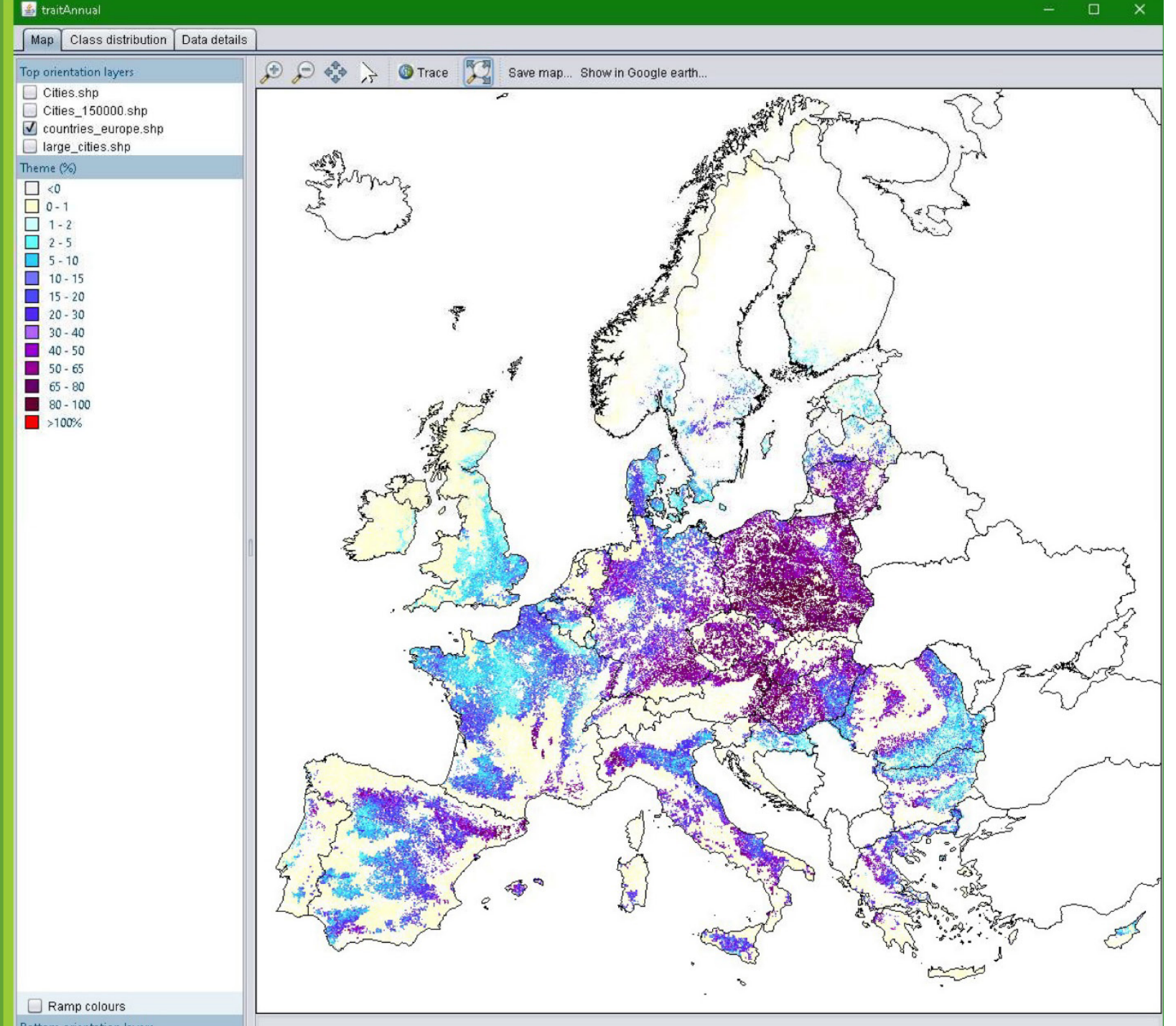




\section{V13 Traits \\ Non-annual}

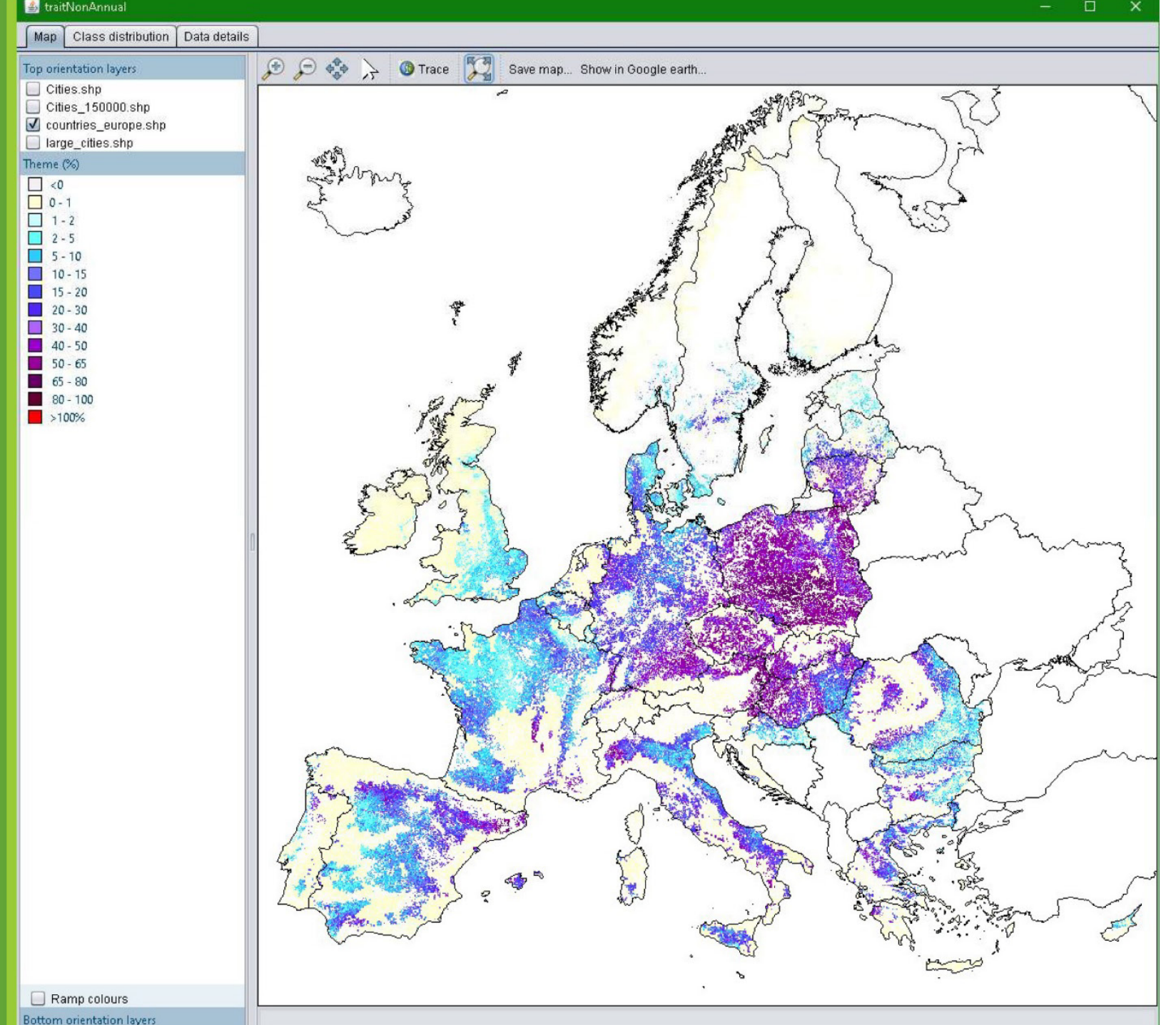




\section{V34 Traits}

Annual

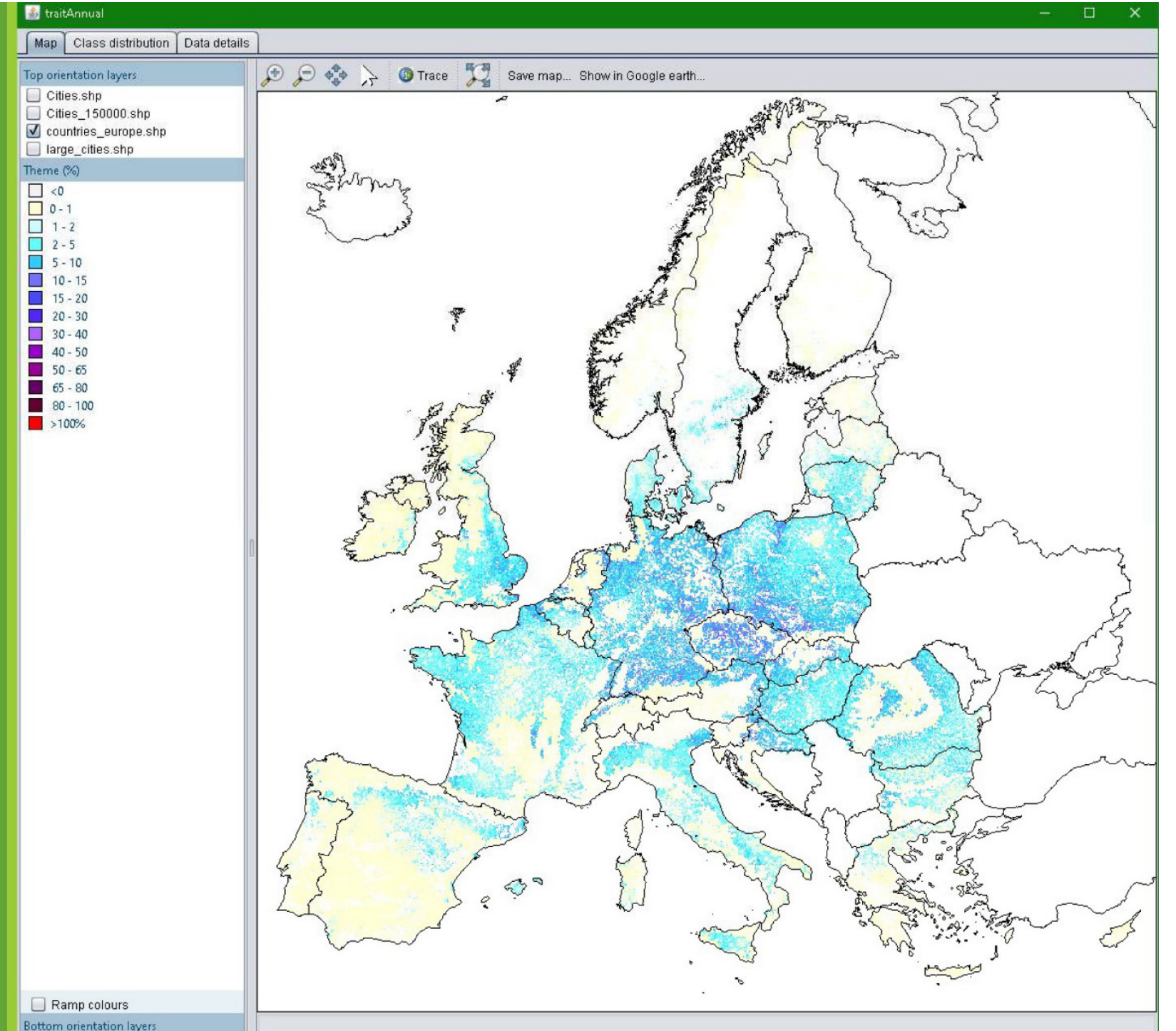




\section{V34 Traits Non-annual}

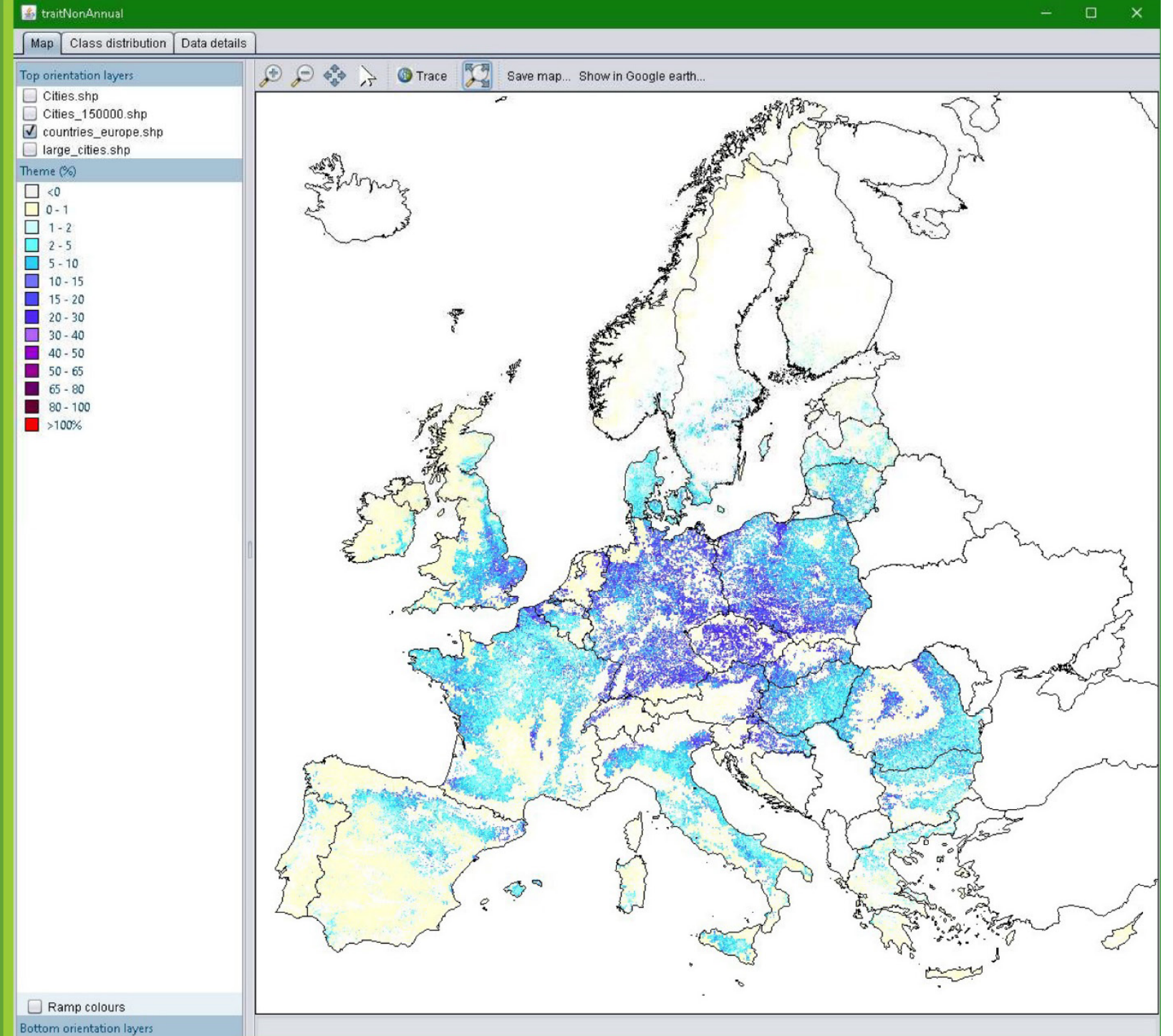




\section{V35 Traits}

Annual

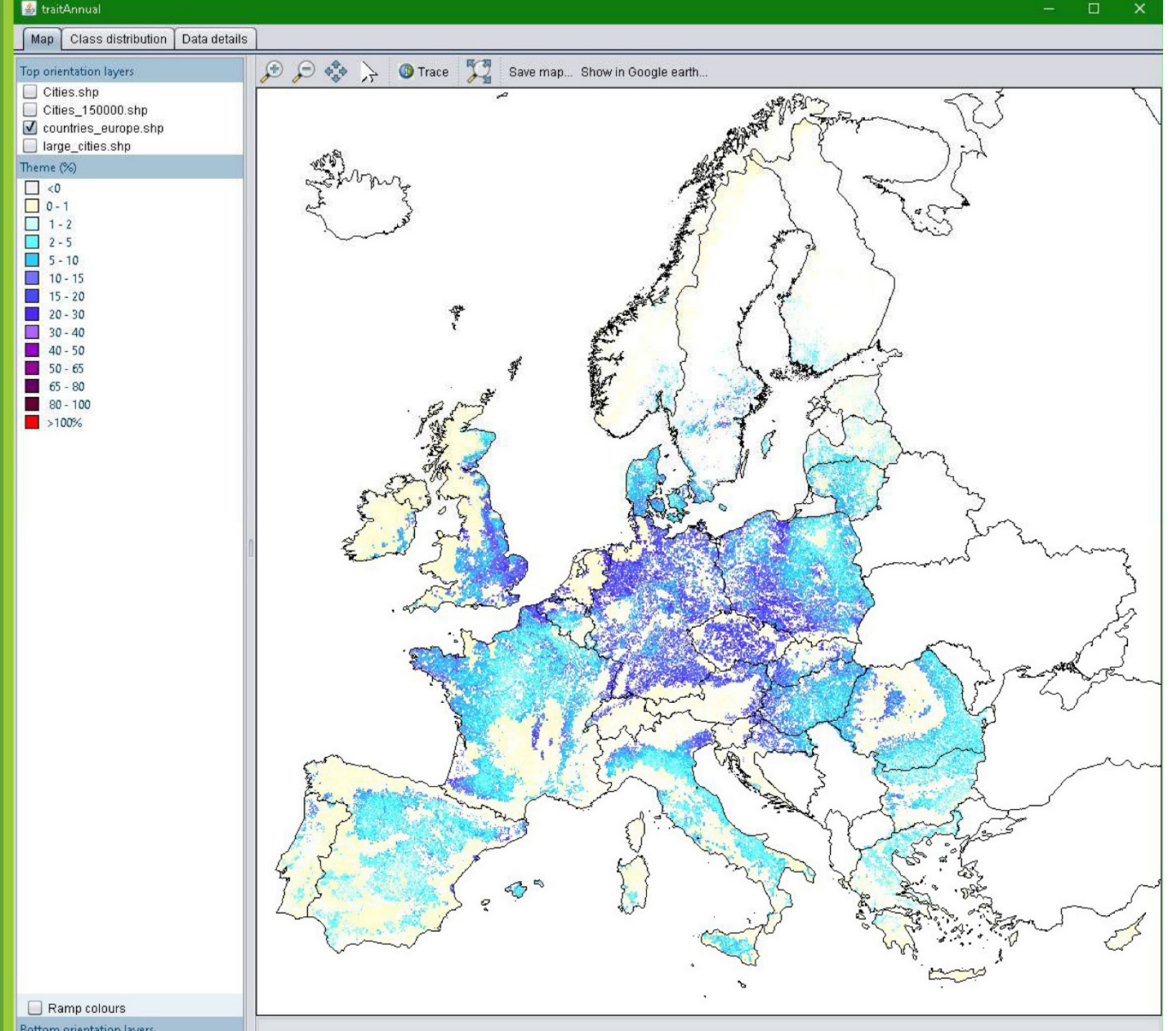


V35 Traits Non-annual

매돌

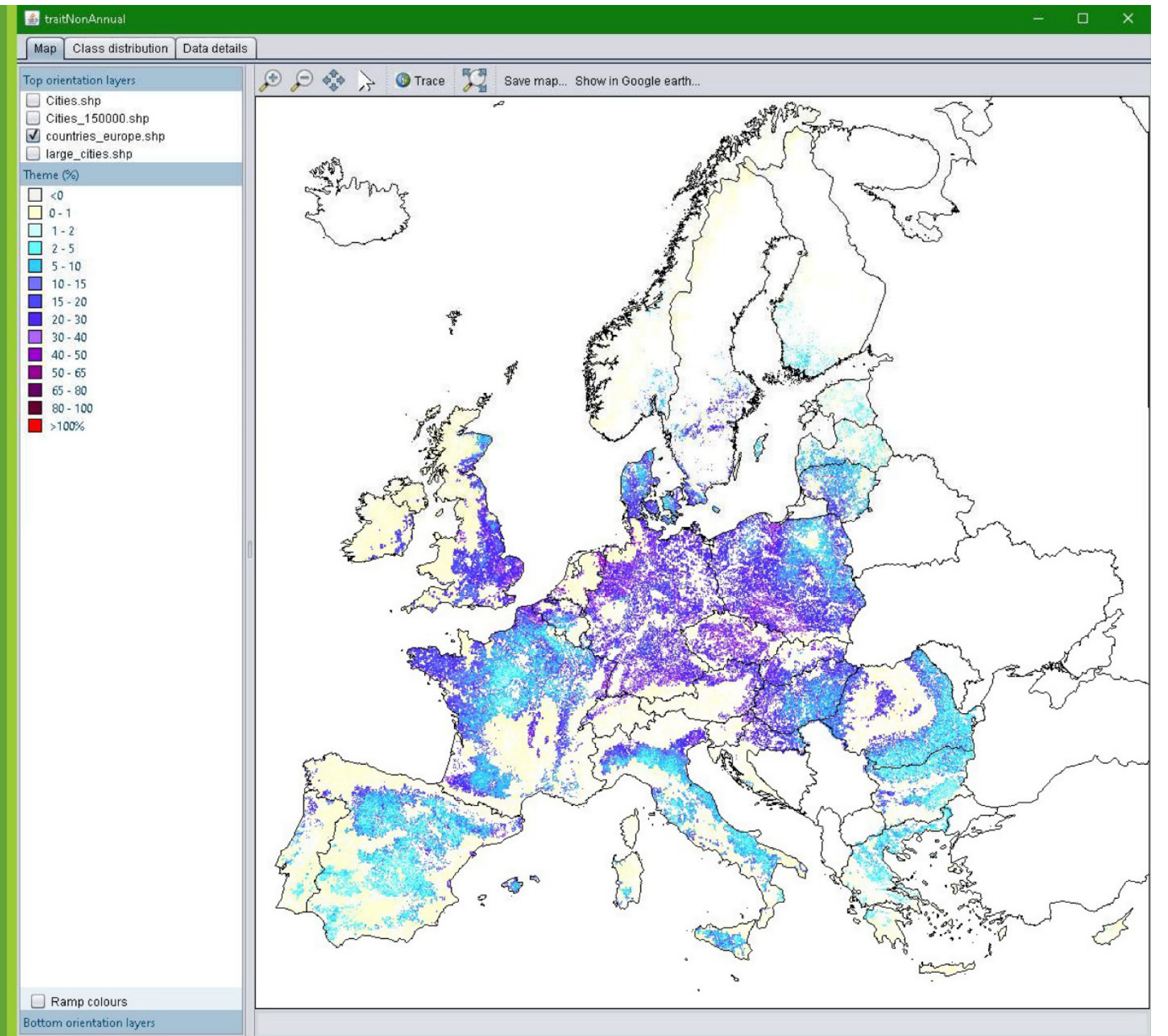




\section{V37 Traits}

Annual

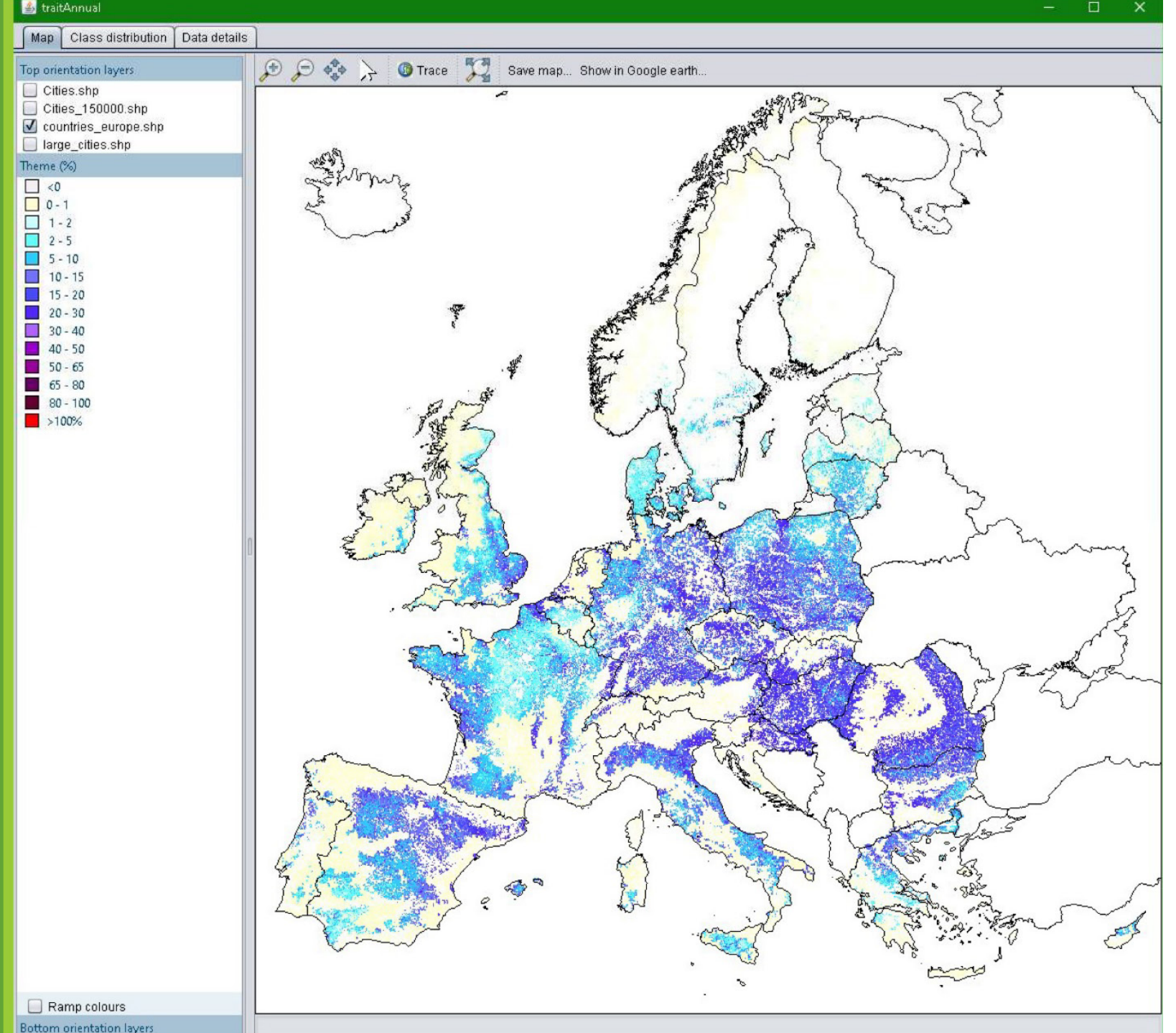




\section{V37 Traits Non-annual}

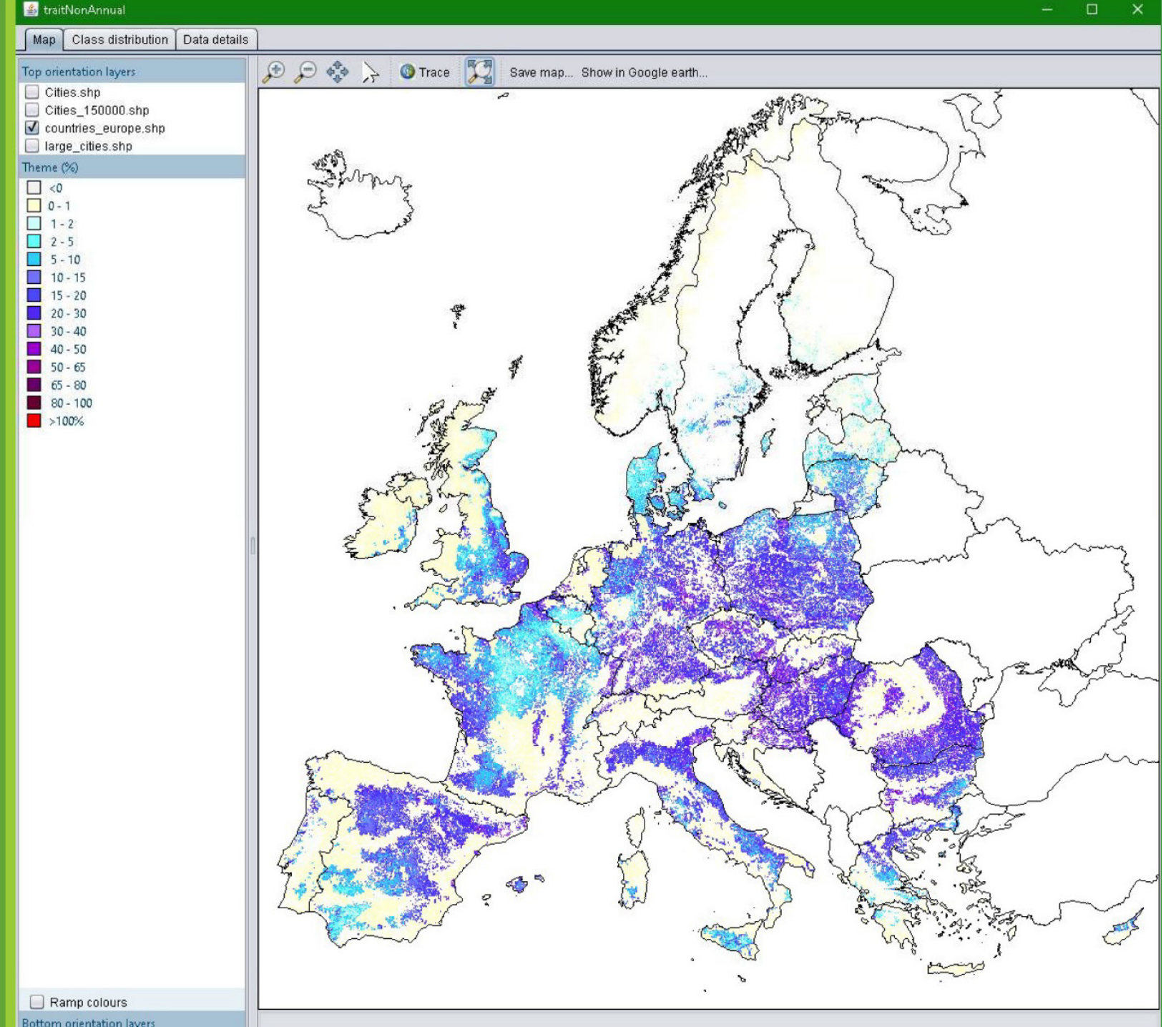


V38 Traits Annual

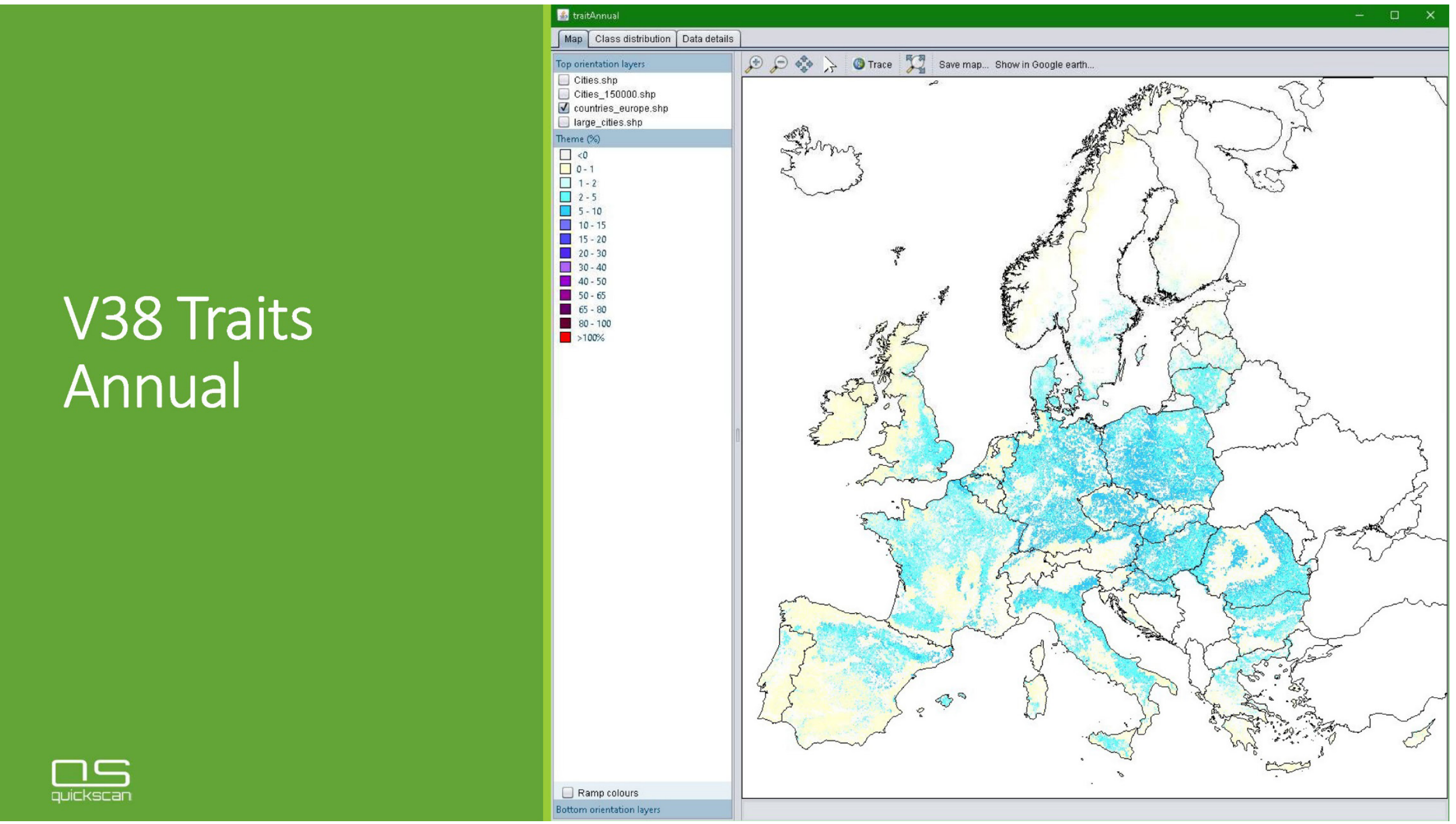




\section{V38 Traits}

Non-annual

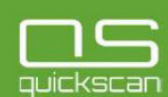

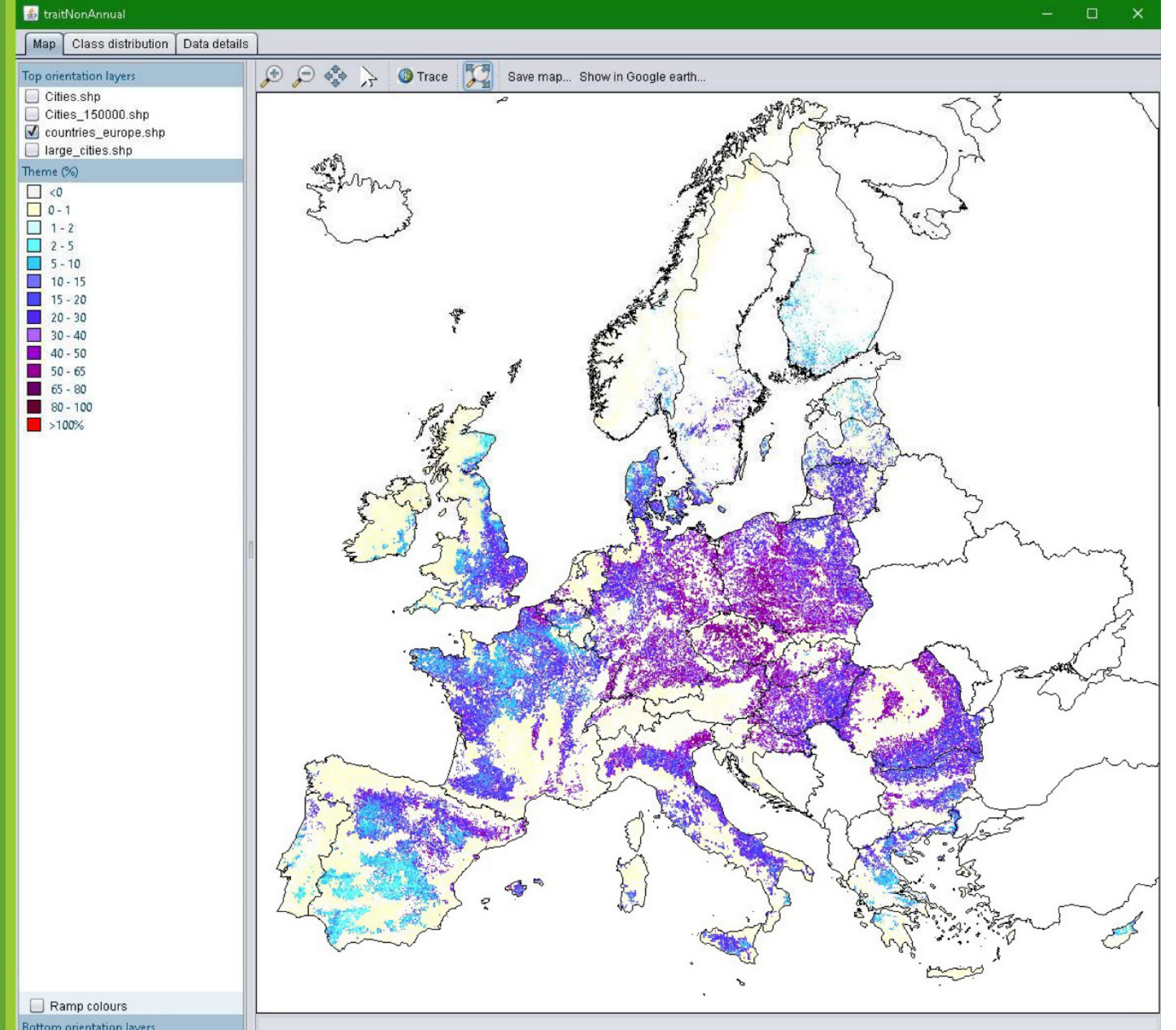




\section{V39 Traits Annual}

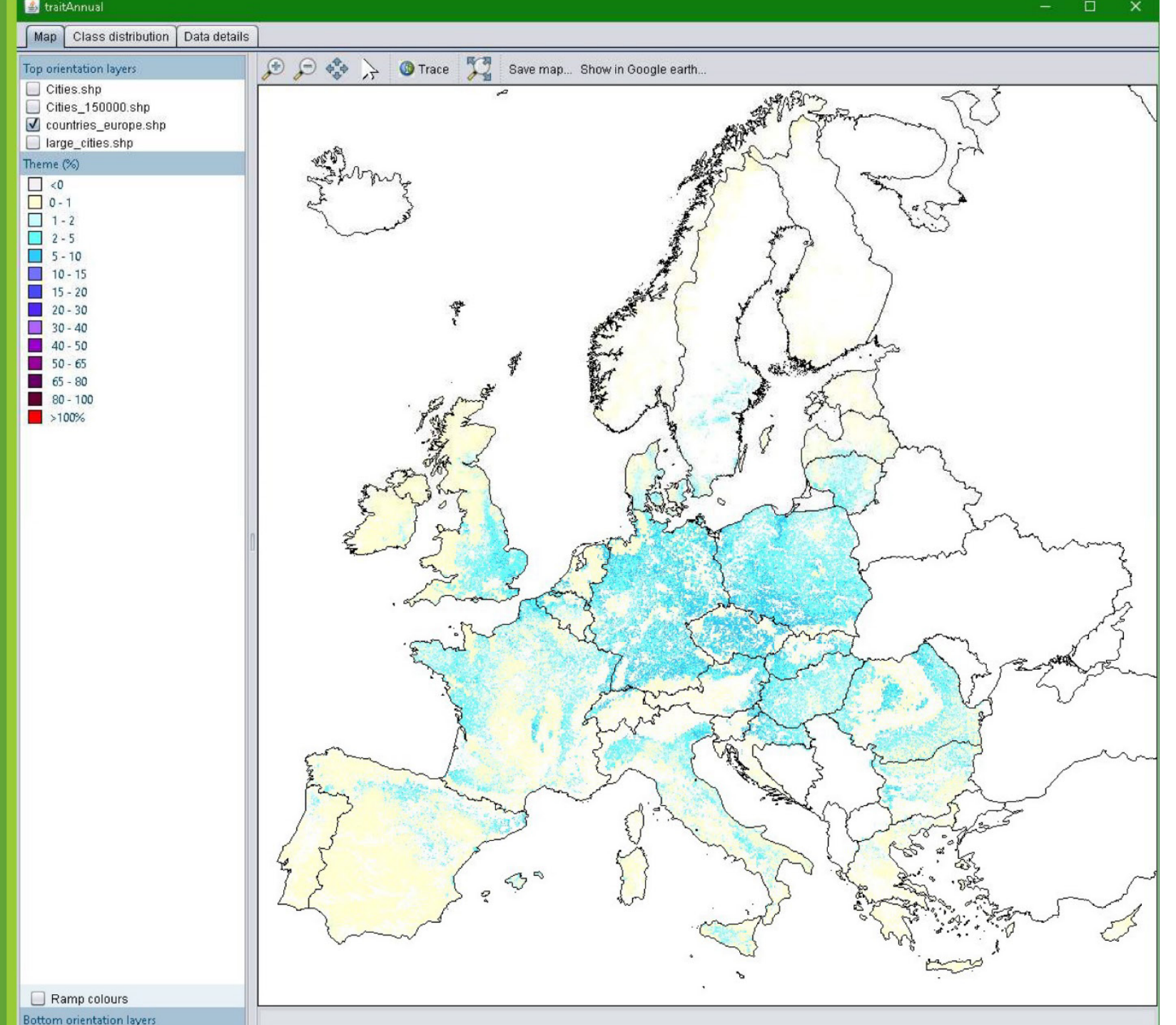




\section{V39 Traits}

Non-annual

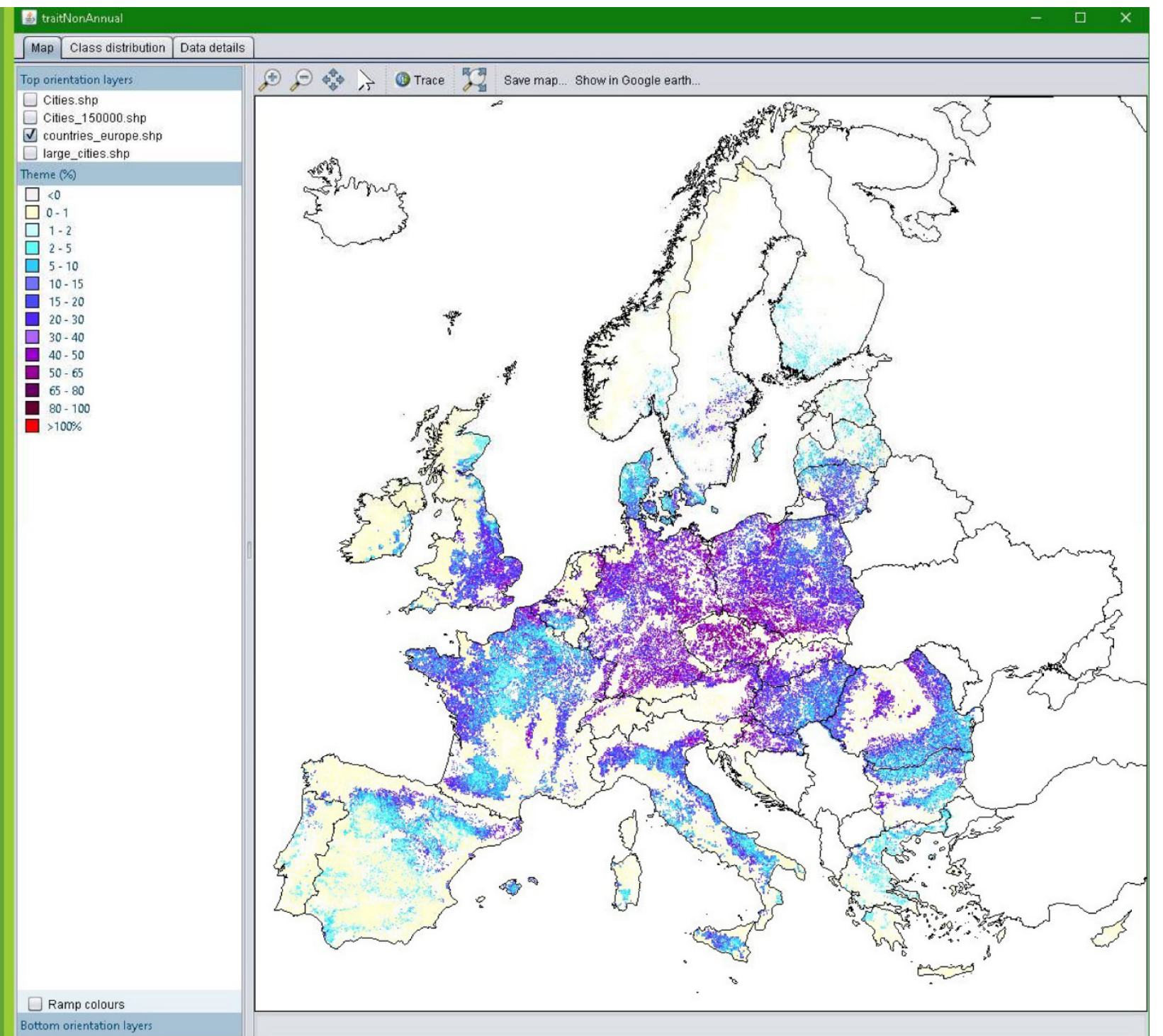




\section{Vineyards}

HABITAT SUITABILITY \&

POTENTIAL OCCURRENCE (SUITABILITY X FSS2010-CROP PRESENCE) 


\section{Vinyards FSS2010}

(\% ha / total ha crops)

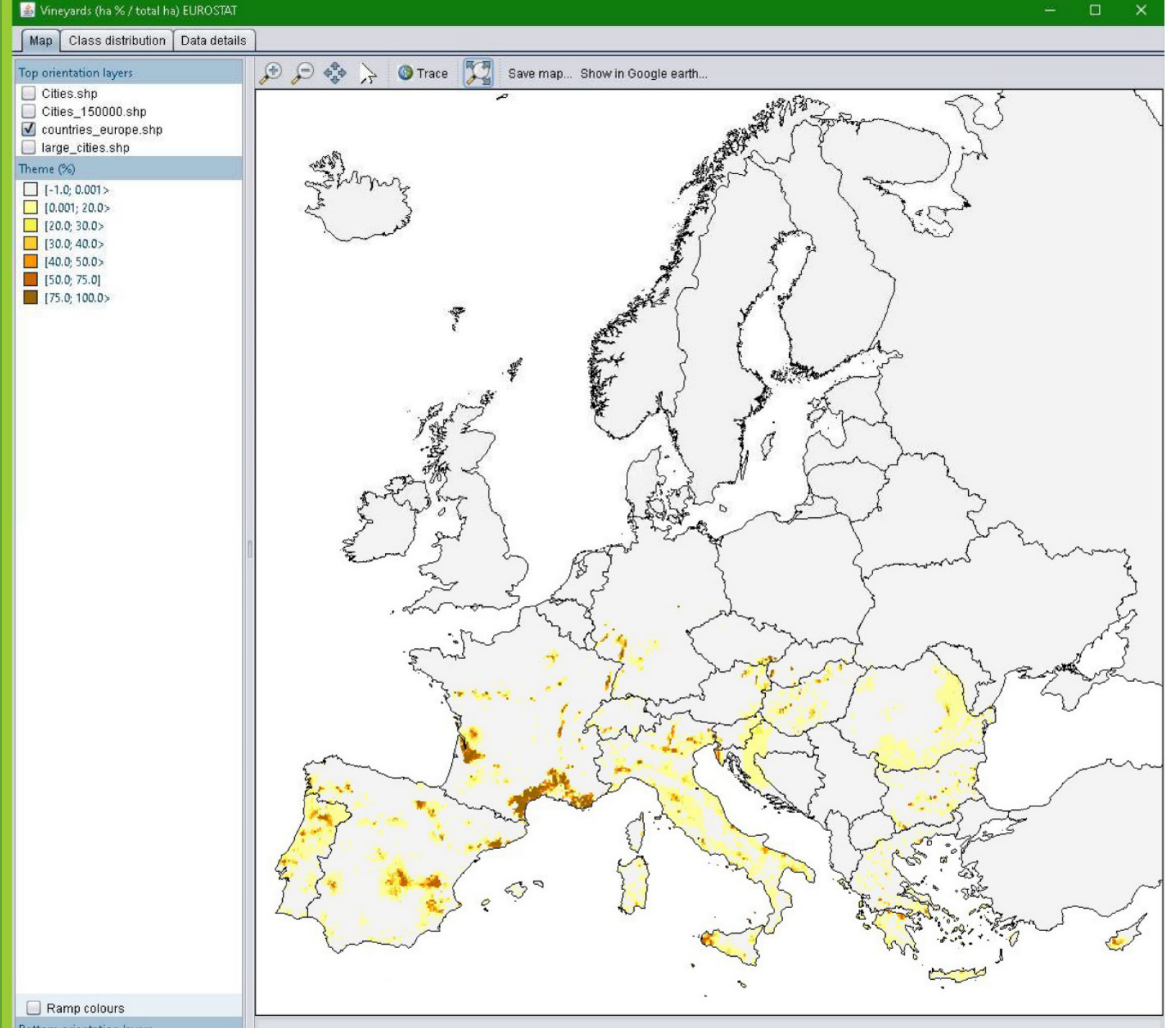




\section{Vineyards FSS2010 $\mathrm{x}$ Agricultural Mask}

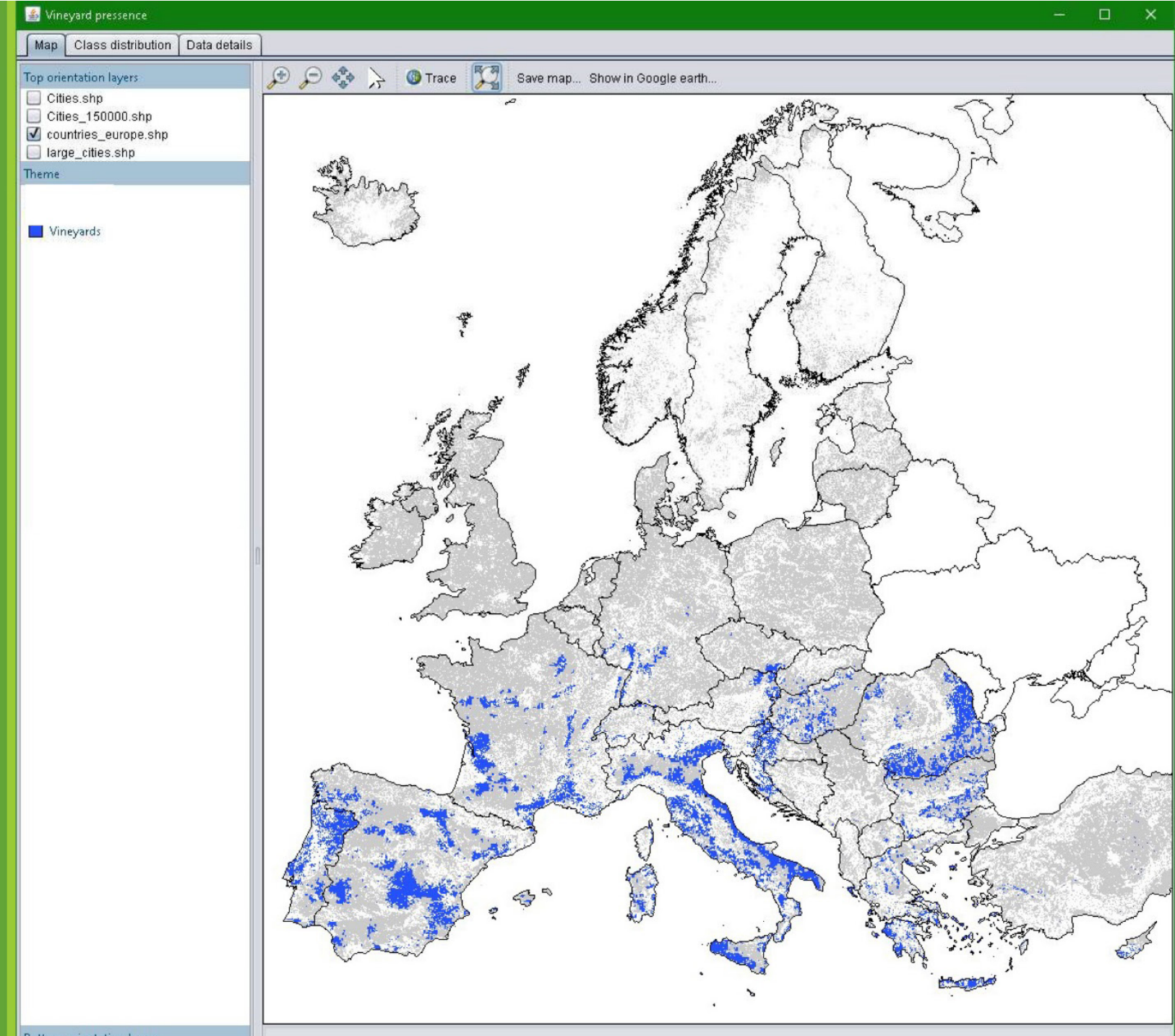




\section{V11} potential occurrence Vineyards

\section{마달}

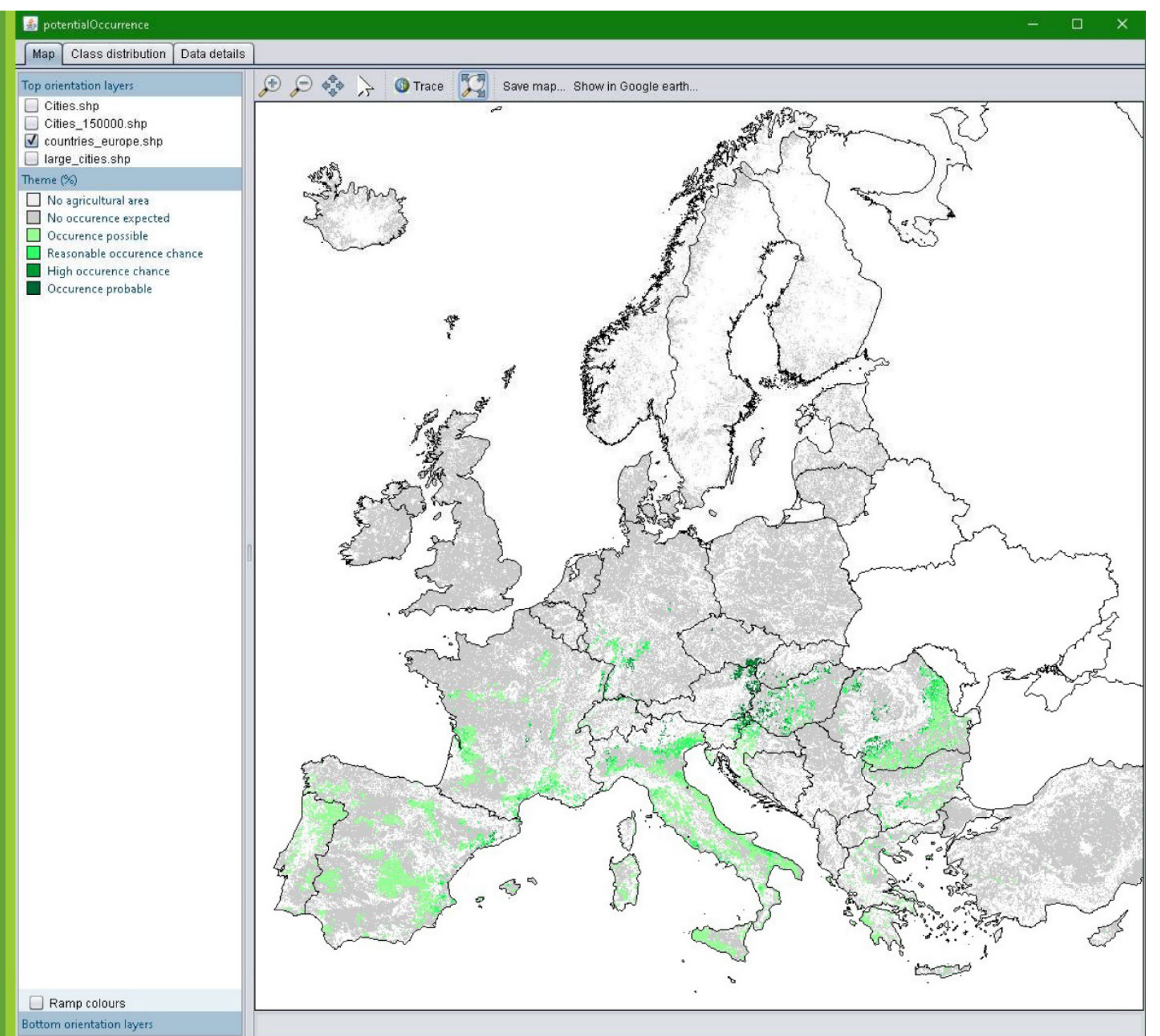




\section{V12 potential occurrence Vineyards}

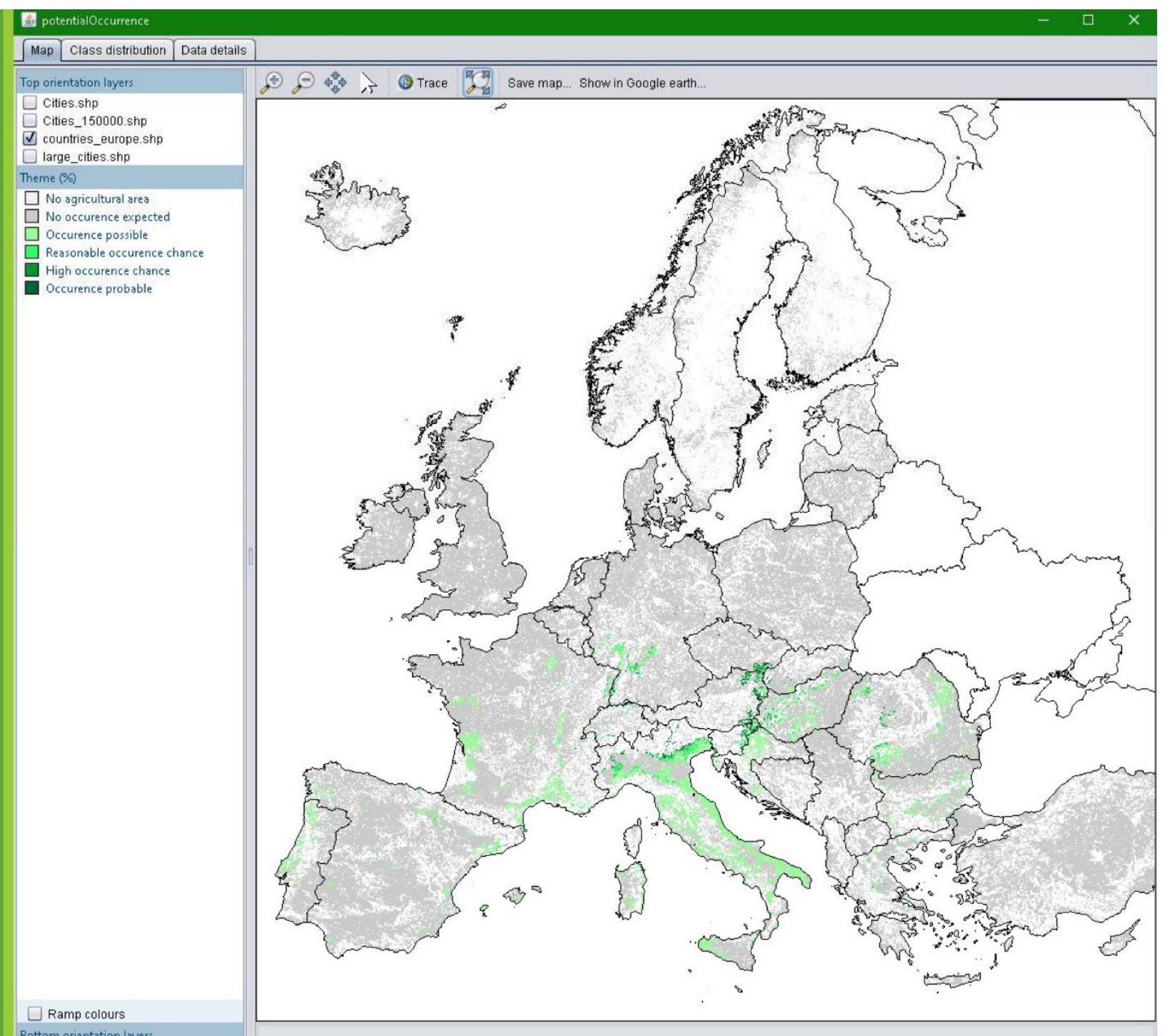




\section{V13}

potential

occurrence

Vineyards

매도를

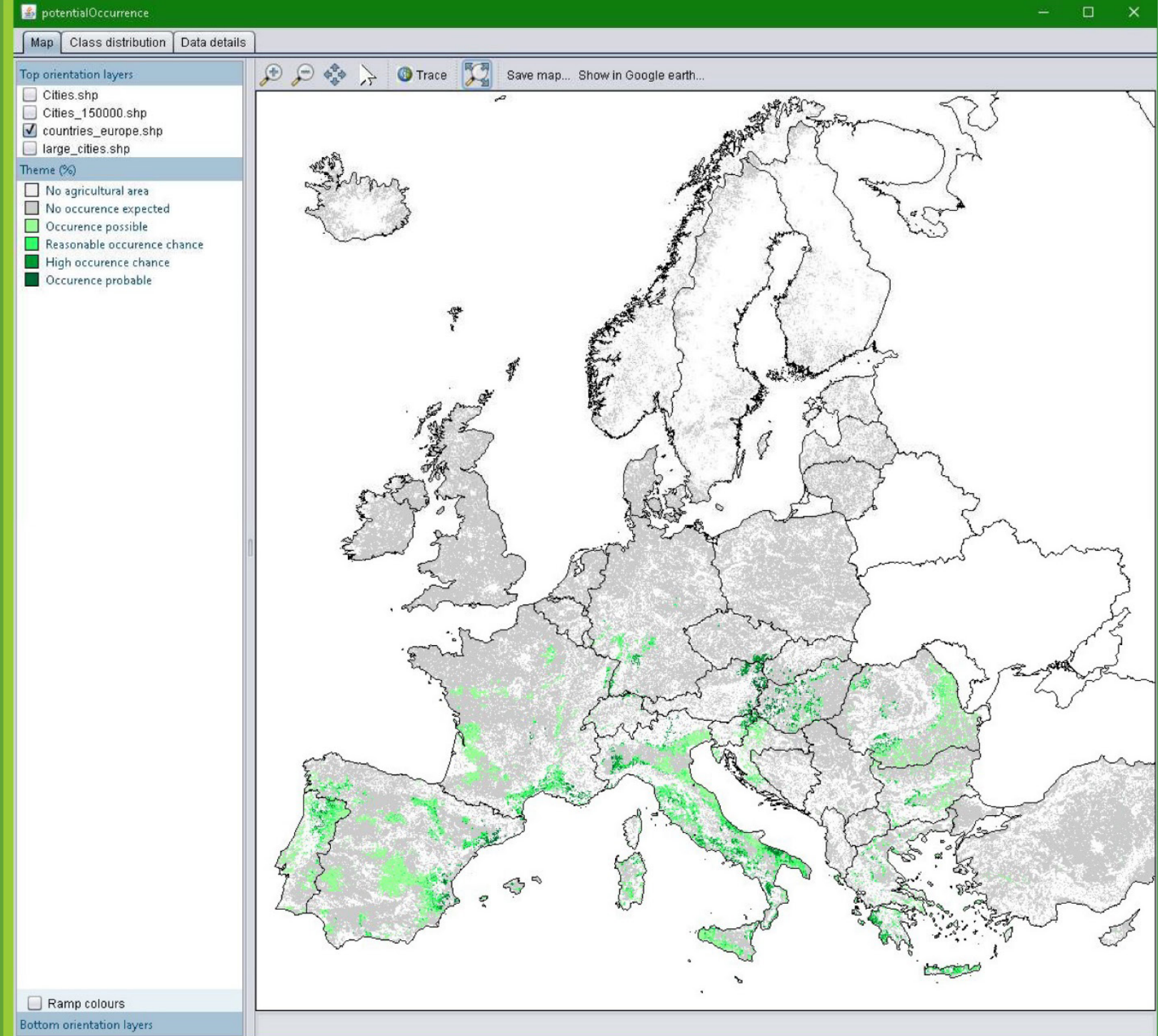




\section{V34 potential occurrence Vineyards}

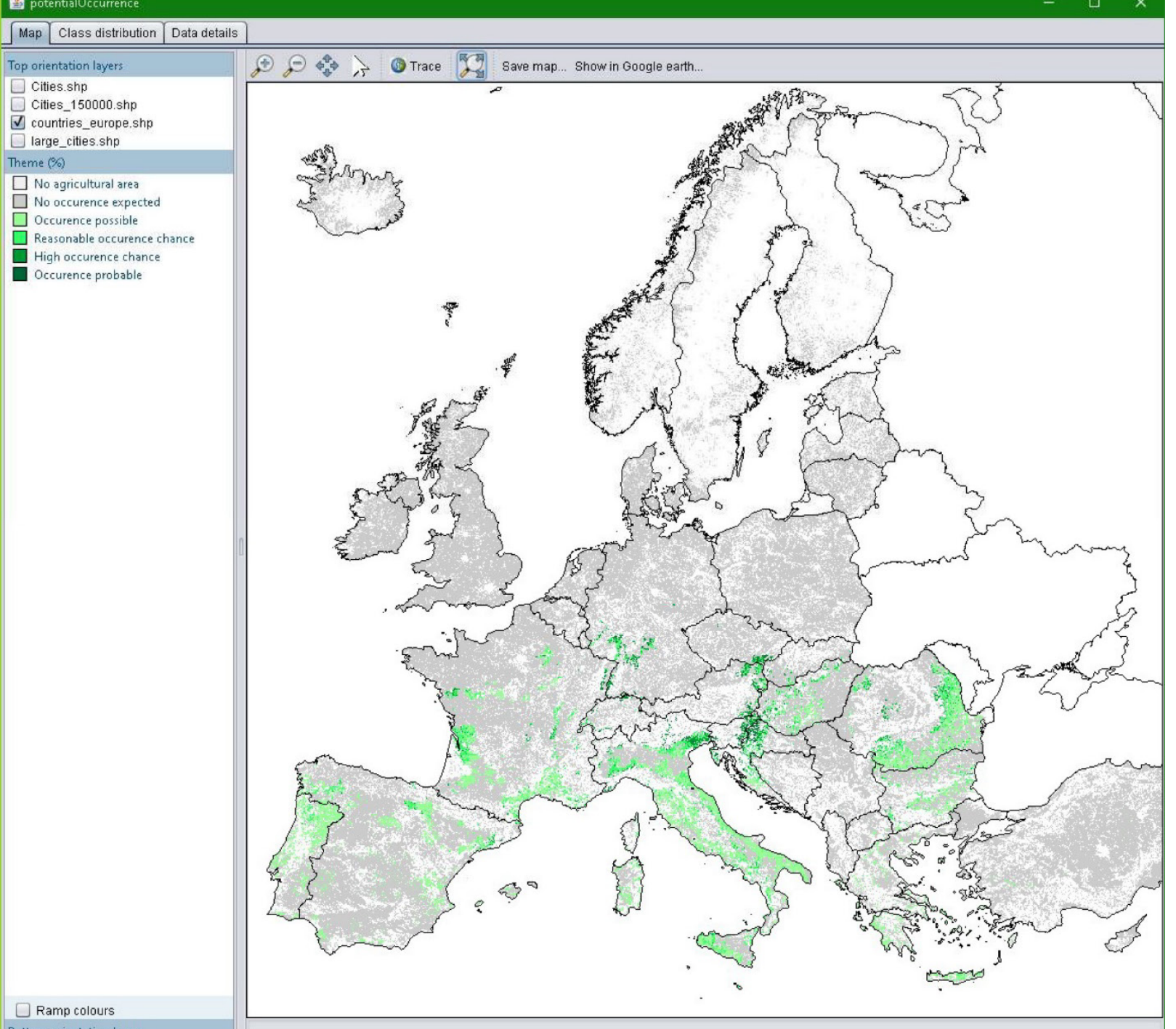


V35 potential occurrence Vineyards

그동

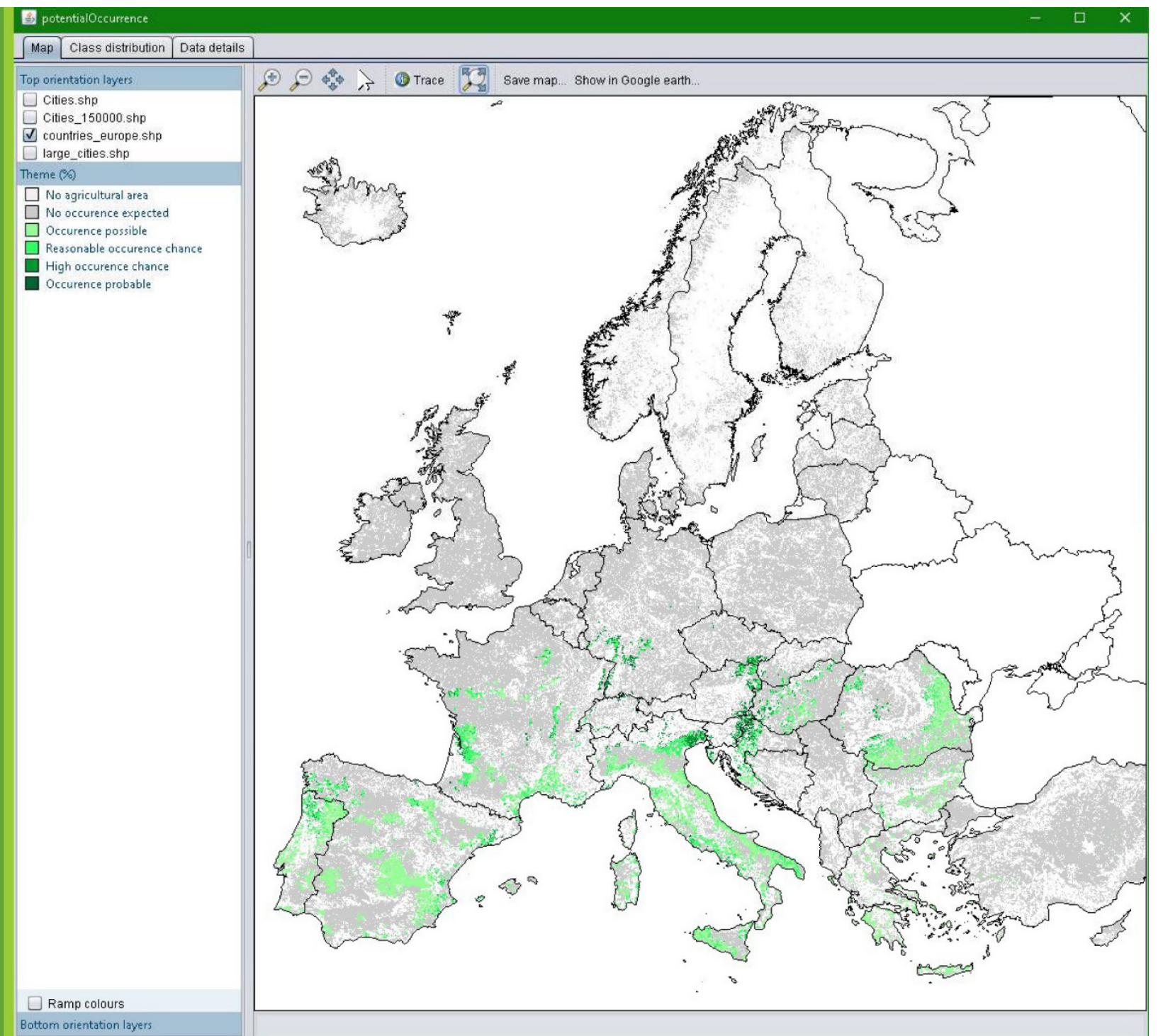




\section{V37 potential occurrence Vineyards}

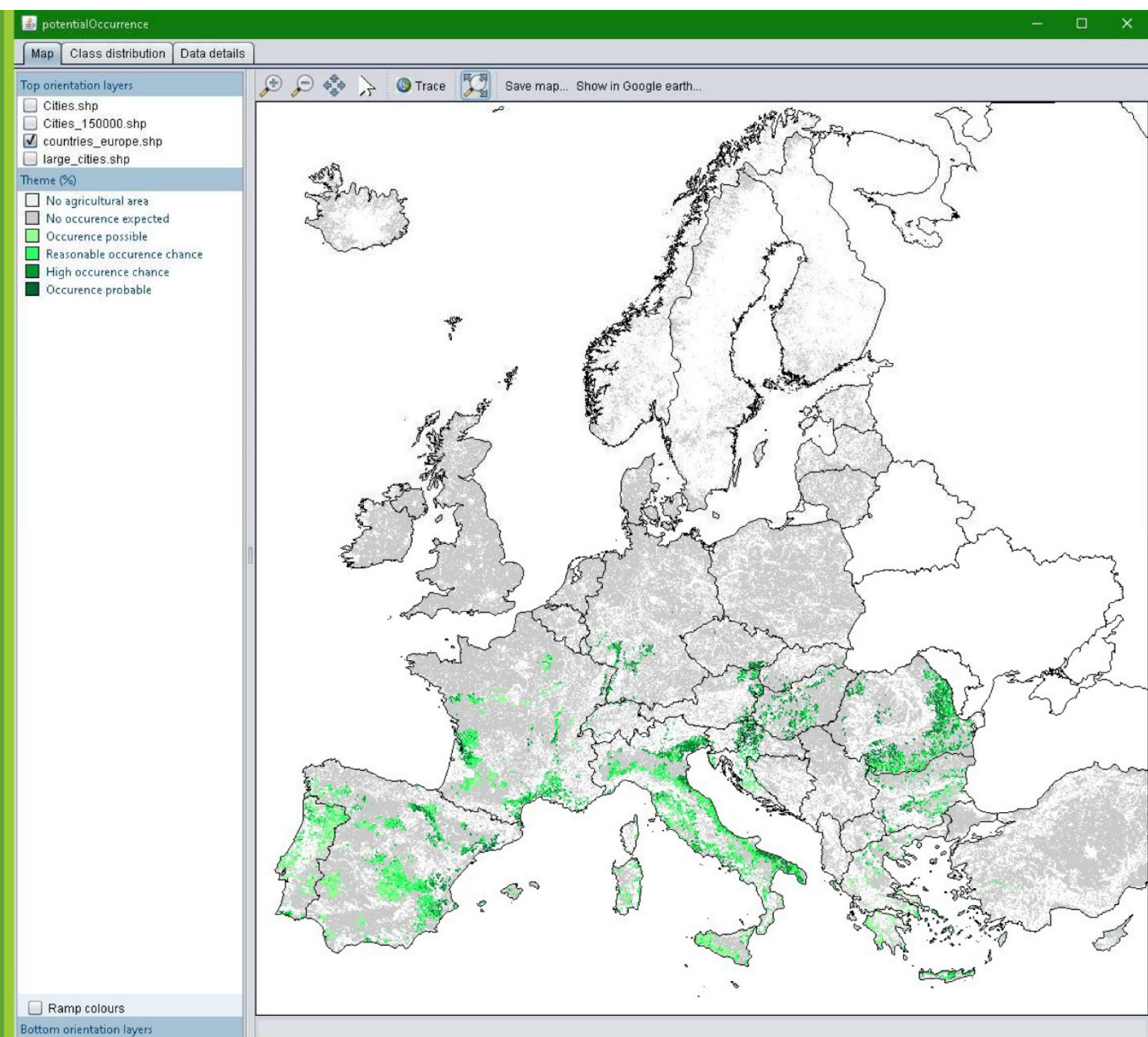




\section{V38}

potential occurrence Vineyards

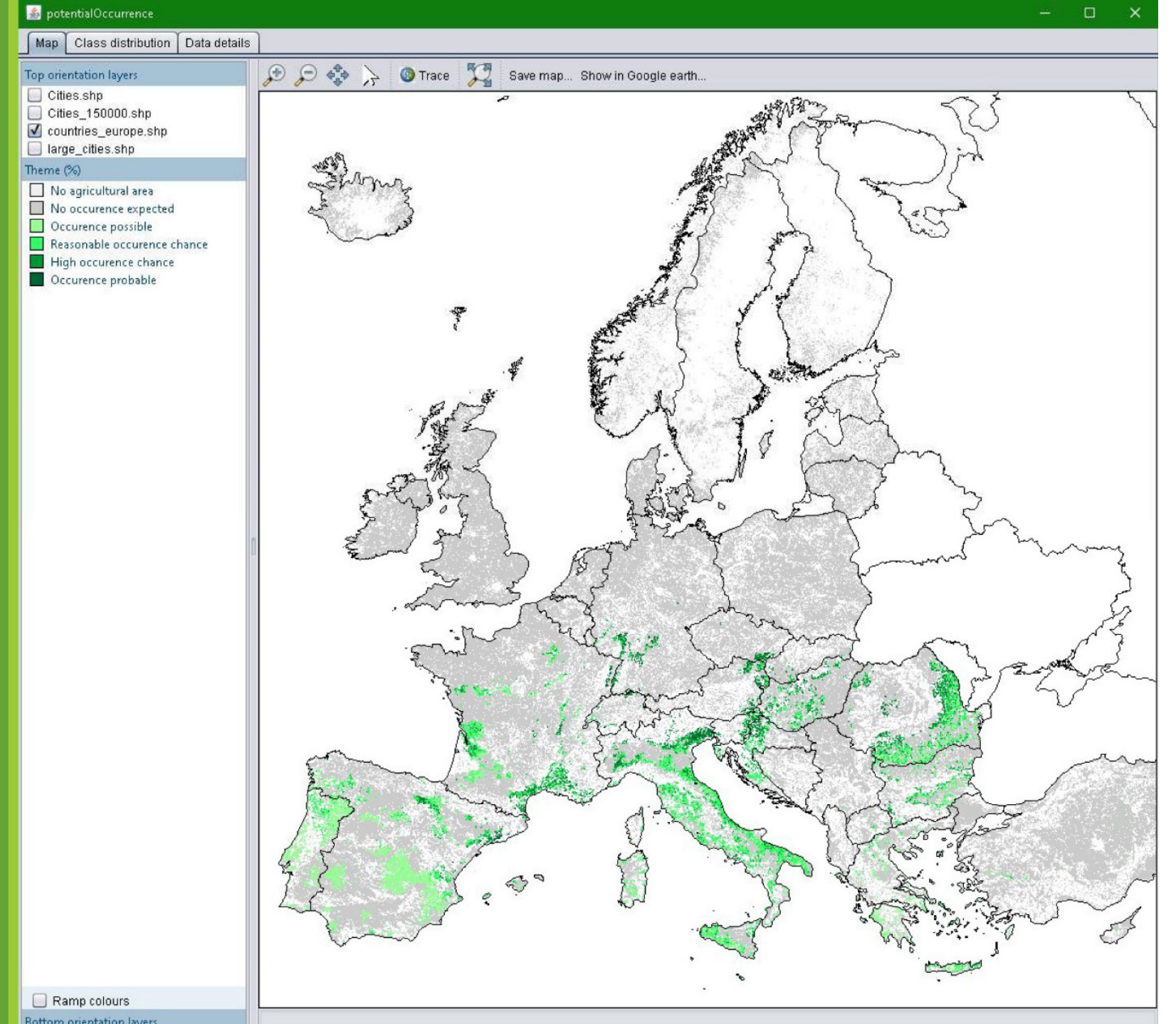




\section{V39 potential occurrence Vineyards}

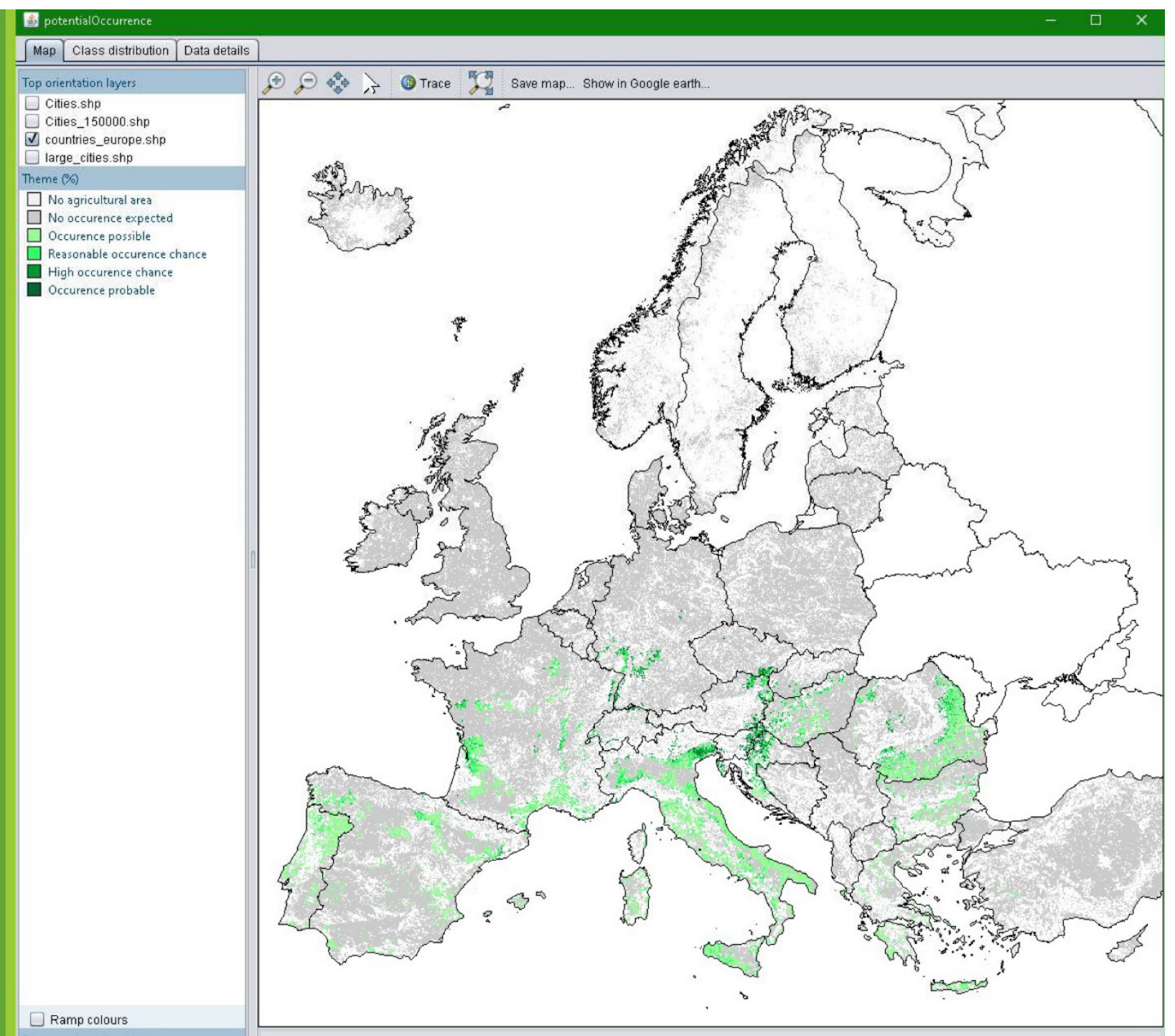


Wageningen Environmental Research P.O. Box 47

6700 AA Wageningen

The Netherlands

T +31 (0)317480700

www.wur.nl/environmental-research

Wageningen Environmental Research Report 3096

ISSN 1566-7197
The mission of Wageningen University \& Research is "To explore the potential of nature to improve the quality of life". Under the banner Wageningen University \& Research, Wageningen University and the specialised research institutes of the Wageningen Research Foundation have joined forces in contributing to finding solutions to important questions in the domain of healthy food and living environment. With its roughly 30 branches, 6,800 employees (6,000 fte) and 12,900 students, Wageningen University \& Research is one of the leading organisations in its domain. The unique Wageningen approach lies in its integrated approach to issues and the collaboration between different disciplines.

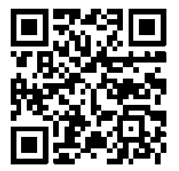




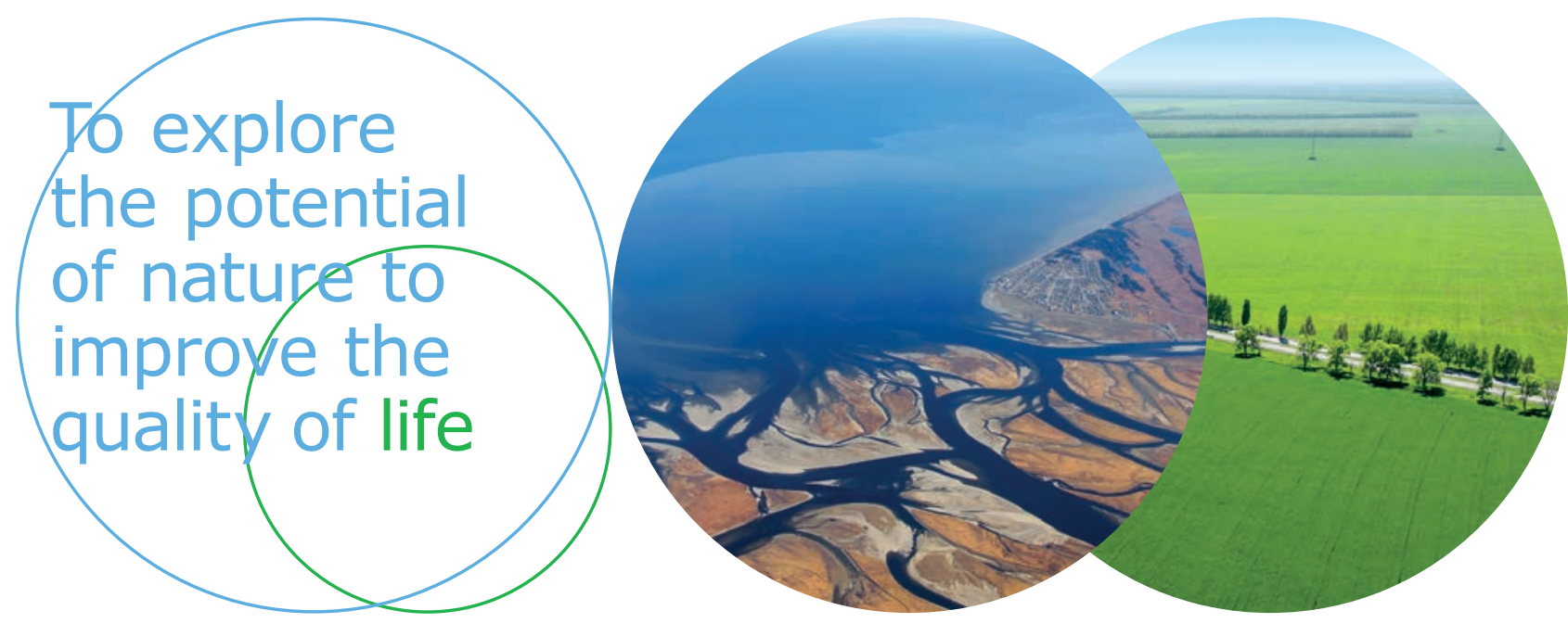

Wageningen Environmental Research P.O. Box 47

$6700 \mathrm{AB}$ Wageningen

The Netherlands

$\mathrm{T}+31(0) 317480700$

www.wur.eu/environmental-research

Report 3096

ISSN 1566-7197
The mission of Wageningen University \& Research is "To explore the potential of nature to improve the quality of life". Under the banner Wageningen University \& Research, Wageningen University and the specialised research institutes of the Wageningen Research Foundation have joined forces in contributing to finding solutions to important questions in the domain of healthy food and living environment. With its roughly 30 branches, 6,800 employees (6,000 fte) and 12,900 students, Wageningen University \& Research is one of the leading organisations in its domain. The unique Wageningen approach lies in its integrated approach to issues and the collaboration between different disciplines. 